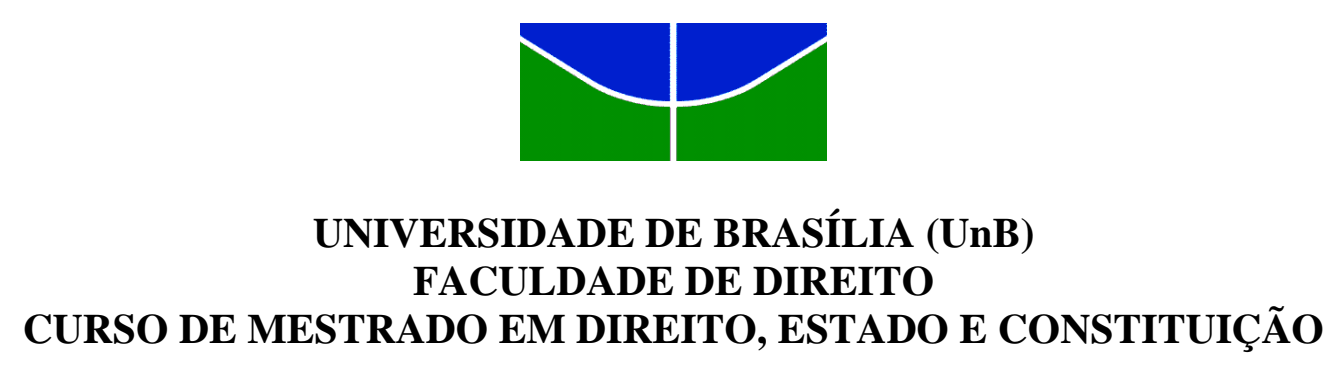

MARIANA CARVALHO DE ÁVILA NEGRI

PROPRIEDADE E REGULARIZAÇÃO FUNDIÁRIA NA AMAZÔNIA LEGAL: OS PROPÓSITOS DA NORMA E A PROPRIEDADE AMAZÔNICA COMO UMA NOVA INSTITUIÇÃO

Brasília (DF)

2015 

INSTITUIÇÃO

Dissertação apresentada ao Curso de Mestrado da Faculdade de Direito da Universidade de Brasília, como requisito parcial à obtenção do título de Mestre em Direito, Estado e Constituição.

Orientador: Prof. Dr. Cláudio Ladeira de Oliveira 


\title{
PROPRIEDADE E REGULARIZAÇÃO FUNDIÁRIA NA AMAZÔNIA LEGAL: OS PROPÓSITOS DA NORMA E A PROPRIEDADE AMAZÔNICA COMO UMA NOVA INSTITUIÇÃO
}

\begin{abstract}
Dissertação apresentada ao Curso de Mestrado da Faculdade de Direito da Universidade de Brasília, como requisito parcial à obtenção do título de Mestre em Direito, Estado e Constituição.

Orientador: Prof. Dr. Cláudio Ladeira de Oliveira
\end{abstract}

Banca Examinadora:

Prof. Dr. Cláudio Ladeira de Oliveira - UnB (orientador)

Prof. Dr. Alexandre Veronese - UnB

Prof. Dr. Adriano De Bortoli - UFSC

Prof. Dr. Juliano Zaiden Benvindo - UnB (suplente) 


\section{AGRADECIMENTOS}

Agradeço a Deus, por guiar cada um dos meus passos. Aos meus pais, Ana Rita e Sérgio, pelos exemplos de vida e pelo apoio em todas as minhas escolhas. À querida vó Ewanda, que sei que me acompanha, de onde estiver, com a mesma ternura e carinho. Ao Felipe, pelo amor, companheirismo e por confiar em mim, algumas vezes mais do que eu mesma. Às minhas queridas irmãs, Ana Carolina e Luciana, pelo aprendizado diário, amizade e amor verdadeiros. Ao Sérgio e à Joana, por todos os ensinamentos, incentivando-me sempre a trilhar novos desafios.

Agradeço e dedico o presente estudo a toda minha família, amigos de Brasília e de Juiz de Fora, colegas e professores que, de alguma forma, participaram dessa caminhada. Que seja apenas o começo. 
Desconfiai do mais trivial, na aparência singelo. E examinai, sobretudo, o que parece habitual.

Suplicamos expressamente: não aceiteis o que é de hábito como coisa natural, pois em tempo de desordem sangrenta, de confusão organizada, de arbitrariedade consciente, de humanidade desumanizada, nada deve parecer natural nada deve parecer impossível de mudar.

(Bertolt Brecht) 


\section{RESUMO}

O presente trabalho pretende abordar uma noção de propriedade construída a partir de uma visão do direito inspirada no realismo jurídico. Entende-se que a propriedade exerce um papel fundamental na sociedade, refletindo valores tanto relacionados ao indivíduo, como autonomia e independência, quanto relacionados à comunidade, como responsabilidade social e justiça distributiva. A propriedade, portanto, dentro da proposta que ora se apresenta, deve ser enxergada como um conjunto de instituições, importantes molduras para as interações interpessoais que se formam a partir do vínculo entre o homem e um determinado recurso. Por sua vez, considerando a referida concepção, passa-se a abordar a regularização fundiária das ocupações de terras públicas federais em áreas rurais na Amazônia Legal. Vislumbra-se a importância de se desvendar os propósitos da norma que dispõe sobre a matéria, a fim de que juízes e tribunais orientem suas decisões com base nesses propósitos, empregando a razão em suas escolhas para uma proteção adequada dos valores presentes na regularização. A partir dessa análise, observa-se que a propriedade resultante desse processo possui contornos bastante específicos, podendo ser entendida como uma instituição da propriedade, aqui referida como a propriedade amazônica.

PALAVRAS-CHAVE: Propriedade. Instituições da propriedade. Valores humanos. Regularização fundiária. Amazônia Legal. 


\begin{abstract}
This study addresses a property concept based on a view of law inspired by legal realism. It is understood that property plays a key role in society, reflecting both individual values, such as autonomy and independence, and social values, such as social responsibility and distributive justice. Thus, property, from the perspective presented here, should be seen as a set of institutions, which represent important default frameworks of interpersonal interaction formed from the bond between man and a given resource. In turn, based on that concept, this paper discusses an analysis of the regularization of occupations of federal public lands in rural areas in the Legal Amazon. Attention is paid to the importance of revealing the purposes of the law, which judges and courts should use to guide their decisions, using reason in their choices for adequate protection of the human values present in regularization. Drawing on this analysis, it is observed that the resulting ownership of this process has very specific features and can be understood as an institution of property, herein referred to as the Amazon property.
\end{abstract}

KEYWORDS: Property. Institutions of property. Human values. Land regularization. Legal Amazon. 


\section{SUMÁRIO}

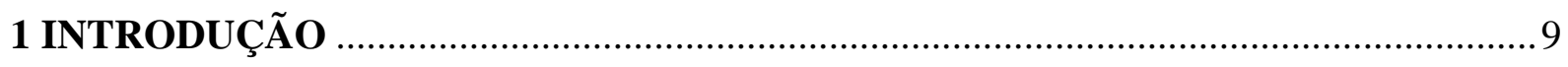

2 PROPRIEDADE: CONSTRUINDO UM CONCEITO .............................................. 12

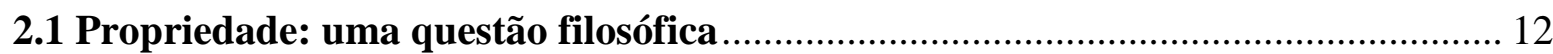

2.1.1 Platão e Aristóteles: propriedade coletiva X propriedade privada........................... 14

2.1.2 São Tomás de Aquino: o bem comum acima do bem particular ............................ 15

2.1.3 Hobbes e Hume: a propriedade enquanto criação humana ..................................... 18

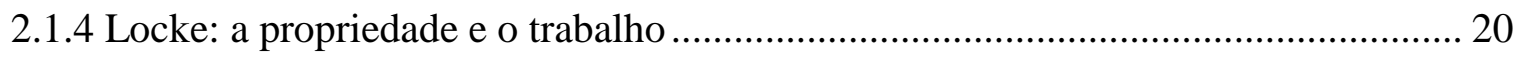

2.1.5 Kant: propriedade, vontade e ação humana ......................................................... 22

2.1.6 Hegel e Marx: propriedade e responsabilidade social......................................... 27

2.1.7 Uma questão filosófica conectada à realidade: a contribuição de Dagan na construção de um conceito contemporâneo de propriedade............................................. 31

2.2 Propriedade: a complexidade do conceito e as dificuldades de sua definição......... 32

2.3 Propriedade enquanto conjunto de instituições: a inspiração na construção do

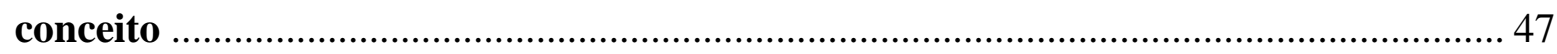

2.3.1 O realismo jurídico: breves noções gerais sobre as premissas que inspiraram a construção de um conceito contemporâneo de propriedade.............................................. 49

2.3.2 A influência do realismo jurídico na concepção de propriedade ............................. 52

2.3.3 Propriedade: tanto forma, quanto substância .................................................... 56

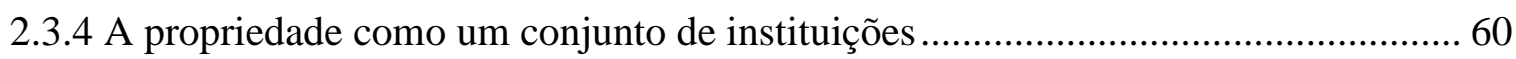

3 A REgULARIZAÇÃo FUNDIÁRIA NO ÂMBITO DA AMAZÔNIA LEGAL E A

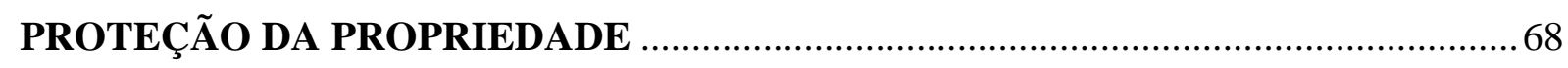

3.1 A legitimação de posse no Brasil: um breve panorama histórico do regime de

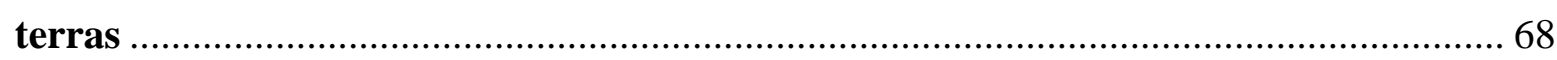

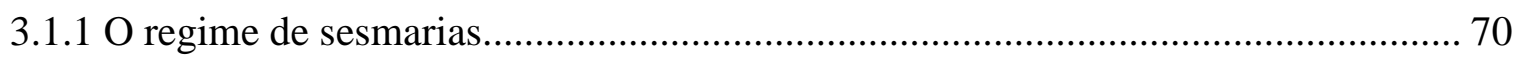

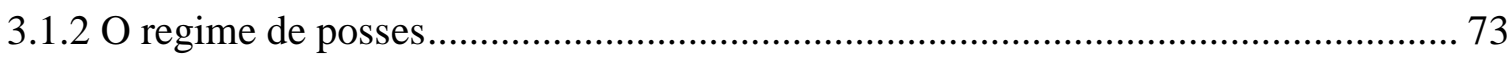


3.1.3 A Lei de Terras e a legitimação de posse

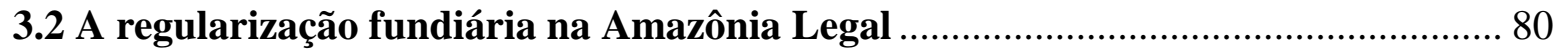

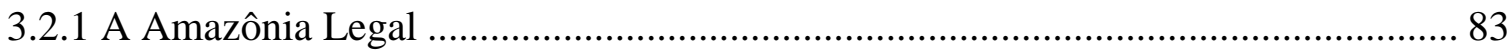

3.2.2 A Lei $\mathrm{n}^{\mathrm{o}}$ 11.952, de 2009 e a política pública de regularização fundiária na

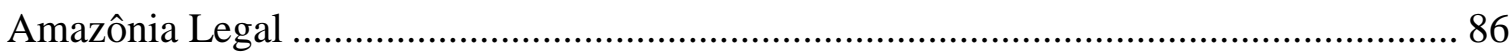

3.2.3 A Lei $\mathrm{n}^{\circ}$ 11.952, de 2009 e as diferentes instituições da propriedade...................... 90

3.2.4 Os requisitos para a regularização fundiária: da situação fática tutelada................. 94

3.2.5 A concessão do título de domínio: das condições para a manutenção da propriedade 100

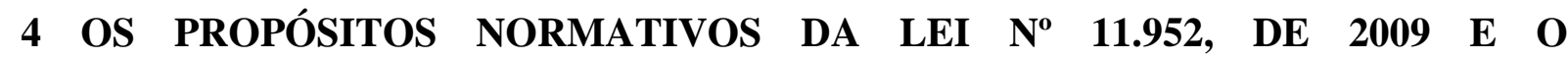
RECONHECIMENTO DE UMA NOVA INSTITUIÇÃO DA PROPRIEDADE: A

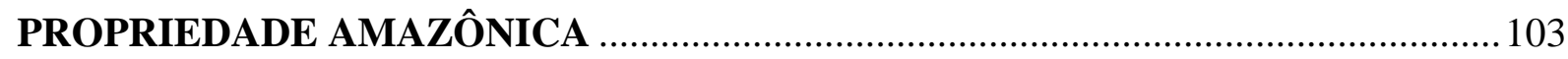

4.1 Os propósitos normativos subjacentes à regularização fundiária na Amazônia

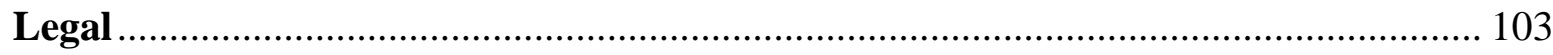

4.2 Uma nova instituição da propriedade: a propriedade amazônica ........................ 113

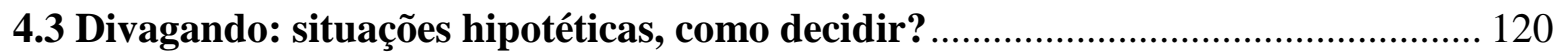

4.3.1 Fragmentação da propriedade rural ............................................................... 121

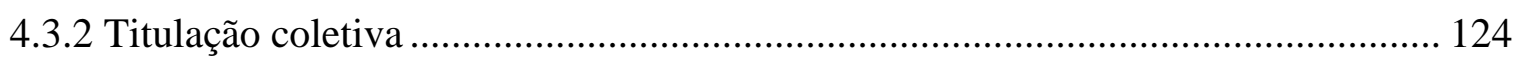

4.3.3 A titulação de terras quilombolas por terceiros.................................................. 126

4.4 Incoerências: propósitos normativos versus dispositivos legais........................... 127

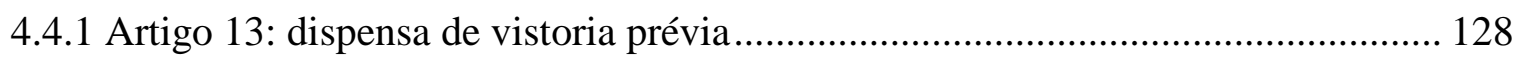

4.4.2 Artigo 15, §2º : a proteção do meio ambiente amazônico...................................... 129

5 CONCLUSÃO

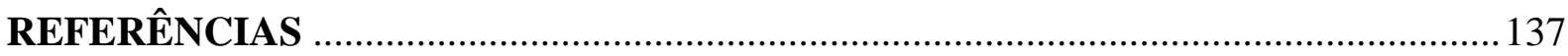




\section{INTRODUÇÃO}

Atualmente, entende-se que não há espaço para uma visão reducionista da propriedade, sendo essa denominação a roupagem de um complexo bastante distinto e independente de relações, no qual estão presentes inúmeros valores, equilibrados de formas diversas e conectados ao contexto em que estão inseridos. Assim, no sentido destacado por Grossi (2006), abordar a concepção de propriedade significa recusar a absolutização da propriedade moderna, produto histórico de uma época, consagração de uma visão individualista e potestativa, que representa, na verdade, apenas uma dentre as múltiplas respostas possíveis, encontradas em meio a inúmeras experiências jurídicas, do passado e do presente, ao eterno problema das relações entre homens e coisas (GROSSI, 2006, p. 11-12).

Em nosso ordenamento jurídico, percebe-se que o Código Civil, em consonância com a Constituição Federal de 1988, reflete uma visão social e múltipla da propriedade, reconhecendo tratar-se de um importante instrumento de concretização de valores humanos. Em contraposição ao modelo individualista destacado por Grossi (2006), o diploma civilista estabelece que a propriedade deve ser exercida de acordo com finalidades econômicas e sociais, sinalizando que não se trata apenas de direitos de exclusão ou exclusividade em favor do proprietário, mas, sim, de uma noção extremamente complexa, composta por diversas estruturas e conteúdos substancialmente diferenciados.

Ao lado de sua complexidade, portanto, está a importância social da concepção. Mais do que um tema acessório, a ser tratado de forma exclusivamente pragmática, a propriedade desempenha um papel-chave na sociedade e deve ser analisada abstratamente, enquanto questão filosófica, permitindo que se pense a priori a respeito e que, por conseguinte, se adote uma abordagem de estratégia social e econômica já na construção da concepção.

Vale dizer que a propriedade consiste o objeto de estudo de grandes filósofos e, independentemente do entendimento que se adote quanto ao seu significado ou, mesmo, às bases de sua fundamentação, percebe-se que a ideia carrega em si inúmeros valores que não podem ser desconsiderados pelos atores jurídicos. Liberdade, igualdade, responsabilidade e justiça são noções diretamente relacionadas ao conceito, o qual, a nosso ver, deve ser analisado de forma contextual, a fim de que se possa enxergar e, por conseguinte, tutelar os valores humanos a que a propriedade deve servir.

Nesse sentido, considerando a importância da concepção dentro da sociedade, entendese que a construção de um conceito contemporâneo de propriedade deve se inspirar na 
premissa proposta pelo realismo jurídico, do direito enquanto uma instituição em movimento, um fenômeno social, em constante aperfeiçoamento.

Utilizando, assim, a referida premissa, adota-se, no presente trabalho, a proposição de Dagan (2011) de que a propriedade deve ser entendida como um "guarda-chuva de um conjunto de instituições - instituições da propriedade - que carregam semelhanças entre si" (DAGAN, 2011, p. 42).

Tais instituições da propriedade representam, na verdade, importantes molduras de interações interpessoais, que consolidam as expectativas das pessoas e expressam os ideais normativos do direito para o centro de relações humanas. Nesse sentido, defende-se, ao longo da presente exposição, que, apenas se facilitar as diversas formas de interação humana no formato de diferentes instituições, a propriedade será capaz de promover o valor do pluralismo _ e da liberdade nele reforçado _ e o papel da individualidade na multiplicidade, ambos cruciais para um ideal de justiça.

Normativamente, a propriedade serve a um conjunto de valores individuais e sociais, incluindo-se, dentre eles, tanto utilidade e autonomia, quanto comunidade, trabalho, responsabilidade social e justiça distributiva. A pluralidade da propriedade reflete, justamente, a heterogeneidade de suas manifestações na vida real.

Desse modo, ao se considerar a propriedade um conjunto de instituições, entende-se que as formas da propriedade possuem, ao lado de sua substância, grande importância para a estruturação da concepção. Cada instituição é, portanto, designada para enquadrar o equilíbrio específico entre os valores relevantes da propriedade que melhor se encaixa ao seu conjunto de características sociais. Por conseguinte, diferentes instituições vindicam diferentes pesos entre esses valores, dependendo do contexto, da relação social ali presente e da natureza do recurso.

Diante de tais considerações, propõe-se uma reflexão acerca da regularização fundiária das ocupações incidentes sobre terras da União, em áreas rurais, no âmbito da Amazônia Legal. Como será visto, trata-se de um importante instrumento de legitimação de posse, que enfatiza a relevância do conteúdo da propriedade, ou seja, das relações existentes, de fato, a partir de um vínculo entre o homem e a terra.

Observa-se que, por muito tempo, a concepção de propriedade, assumindo o já mencionado viés individualista, priorizava a forma, em detrimento do conteúdo. A legitimação da posse representa, contudo, o caminho inverso, a retomada do cultivo e de outros elementos caracterizadores da propriedade, inclusive de cunho social, como 
determinantes para que seja conferida a devida tutela estatal. Procura-se demonstrar, assim, que, muito mais que atributos relacionados à exclusão e à exclusividade em favor do proprietário, a propriedade decorrente da regularização fundiária na Amazônia Legal abarca valores ligados à inclusão social do ocupante da terra, à responsabilidade socioambiental, à justiça distributiva e ao próprio desenvolvimento econômico sustentável da região amazônica.

Nesse sentido, o presente trabalho, ao estudar a Lei $\mathrm{n}^{\circ} 11.952$, de 2009, especificamente quanto à regularização das ocupações incidentes em terras da União situadas nas áreas rurais, no âmbito da Amazônia Legal, objetiva analisar o tratamento do legislador conferido à propriedade produto desse tipo de regularização, observando-se uma abordagem bastante específica e contextual, o que, por sua vez, a nosso ver, aproxima-se daquela visão proposta por Dagan (2011), inspirada no realismo jurídico. Pretende-se, assim, considerando a adoção pelo legislador de uma abordagem baseada em categorias mais estreitas da propriedade, desvendar os propósitos da normatização referente à matéria, a fim de que juízes e tribunais orientem suas decisões com vistas a essas finalidades, empregando a razão em suas escolhas para uma tutela efetiva dos valores humanos presentes na regularização. 


\section{PROPRIEDADE: CONSTRUINDO UM CONCEITO}

\subsection{Propriedade: uma questão filosófica}

Grossi (2006), ao tratar da história da propriedade, apresentando, de forma bastante crítica, o que chama de inventário de riscos culturais para o historiador do direito, ressalta que as propriedades não podem ser jamais "criaturas de uma dimensão simplisticamente inseríveis em compartimentos pré-fabricados" (GROSSI, 2006, p. 20). Para o autor, a propriedade consiste em uma mentalidade, ou seja, um complexo de valores circulares em uma área espacial e temporal apto a superar a dispersão de fatos e episódios espalhados e de construir o tecido conectivo "escondido e constante daquela área" (GROSSI, 2006, p. 30).

\footnotetext{
A propriedade é seguramente também um problema técnico, mas nunca é somente, no seu contínuo emaranhar-se com todo o resto, um problema técnico: por debaixo, os grandes arranjos das estruturas; por cima, as grandes certezas antropológicas põem sempre a propriedade no centro de uma sociedade e de uma civilidade. A propriedade não consistirá jamais em uma regrinha técnica, mas em uma resposta ao eterno problema da relação entre homem e coisas, da friç̧ão entre mundo dos sujeitos e mundo dos fenômenos, e aquele que se propõe a reconstruir sua história, longe de ceder a tentações isolacionistas, deverá, ao contrário, tentar colocá-la sempre no interior de uma mentalidade e de um sistema fundiário com função eminentemente interpretativa (GROSSI, 2006, p. 16).
}

Conforme sugere Waldron (2012), mais do que um tema acessório, a ser tratado de forma pragmática, a propriedade desempenha um papel-chave na sociedade e deve ser analisada abstratamente, enquanto questão filosófica (a philosophical issue), permitindo que se pense a priori a respeito e que, por conseguinte, se adote uma abordagem de estratégia social e econômica já na construção da concepção. Toda e qualquer sociedade tem que decidir se sua economia será organizada com base no mercado e na propriedade privada ou, por outro lado, com base em um controle central coletivo, sendo que, segundo Waldron (2012), poucos filósofos, de fato, contribuem para esse debate atualmente.

Todavia, com o aumento da atenção conferida à disciplina das políticas públicas, fica cada vez mais difícil enxergar a propriedade como mera questão acessória e pragmática e, por sua vez, negar que a concepção possa ser colocada em termos abstratos o bastante para merecerem uma abordagem filosófica (WALDRON, 2012). 
Waldron (2012) destaca que, apesar de alguns autores sugerirem que sejam enfatizadas questões de justiça, mais do que, exatamente, de propriedade, o que se observa é que problemas ligados à propriedade implicam, inevitavelmente, problemas de justiça:

\begin{abstract}
Apesar de toda sociedade ter que decidir se a economia será organizada com base no mercado e na propriedade privada ou com base em um controle coletivo central, existem poucos filósofos que poderiam contribuir para esses debates. Filósofos, segundo Rawls, são melhores discutindo princípios abstratos de justiça que deverão condicionar o estabelecimento de qualquer instituição social, do que tentando estabelecer a priori questões de estratégia econômica e social. De outro lado, com o aumento da atenção que vem sendo conferida à disciplina de política pública em geral, é difícil negar que questões sobre propriedade possam ser colocadas em termos abstratos o bastante para que os filósofos abordem. Apesar de Rawls aconselhar que se discuta sobre justiça em vez de propriedade, na verdade questões sobre propriedade implicam inevitavelmente questões sobre justiça que têm preocupado os filósofos políticos nos últimos anos. Certas instituições de propriedade podem ser melhores do que outras para a justiça ${ }^{1}$ (WALDRON, 2012, p. 6-7).
\end{abstract}

Considerando, portanto, que a propriedade relaciona-se diretamente à distribuição de riqueza, à igualdade entre as pessoas e à sua liberdade, entende-se, assim como Waldron (2012), que se deve pensar em um sistema eclético e comprometido com a sociedade como um todo, mais do que um sistema de mercado puro da propriedade privada, alheio às demais dimensões sociais.

Em sua proposta de análise em abstrato da propriedade, Waldron (2012) destaca que a noção e suas bases de justificação foram objeto de reflexão por grandes filósofos, havendo extensas discussões a respeito em textos de Platão, Aristóteles, São Tomás de Aquino, Hegel, Hobbes, Locke, Hume, Kant e Marx. Assim, seguindo as linhas traçadas por Waldron (2012), passa-se a abordar, brevemente, algumas dessas discussões, procurando demonstrar que, longe de se tratar apenas de exclusão e exclusividade, a noção carrega em si inúmeros valores humanos.

\footnotetext{
${ }^{1}$ Tradução livre de: "Although every society has to decide whether the economy will be organized on the basis of markets and private ownership or on the basis of central collective control, there was little that philosophers could contribute to these debates. Philosophers, Rawls said, are better off discussing the abstract principles of justice that should constrain the establishment of any social institutions, than trying to settle a priori questions of social and economic strategy. On the other hand, with the growing attention that is being paid in the discipline to public policy generally, it is difficult to deny that questions about property can be posed in terms that are abstract enough for philosophers to address. Though Rawls counsels us to talk about justice rather than property, in fact issues about property are inevitably implicated in some of the issues about justice that have preoccupied political philosophers in recent years. Certain property institutions may be better than others for justice" (WALDRON, 2012, p. 6-7).
} 
Ademais, as referidas discussões sinalizam a importância e, ao mesmo tempo, a ausência de consenso a respeito do tema, corroborando, ainda, a ideia de que o instituto pode ser enxergado e, por conseguinte, analisado como uma questão filosófica.

\subsubsection{Platão e Aristóteles: propriedade coletiva X propriedade privada}

Em interessante passagem presente no texto de A República, Platão (1949) defende a importância da propriedade coletiva na organização da sociedade, na busca do interesse comum e na tentativa de se evitar uma divisão da cidade de forma "dilacerada e múltipla, em vez de una" (PLATÃO, 1949, 462b).

\footnotetext{
_ Ora nós teremos algum mal maior para a cidade do que aquele que a dilacerar e a tornar múltipla em vez de una? Ou maior bem do que o que a aproximar e tornar unitária?

_ Não temos.

_Logo, a comunidade de prazer e de pena não os une, quando os cidadãos, no maior número possível, se regozijam e se afligem igualmente com as mesmas vantagens e perdas?

- Absolutamente - respondeu ele.

_. E não é o individualismo destes sentimentos que os divide, quando uns sofrem profundamente e outros se regozijam em extremo a propósito dos mesmos acontecimentos públicos ou particulares?

_ Pois não!

_ Ora este facto não provém de os habitantes da cidade não estarem de acordo em aplicar expressões como estas $<<$ meu $>>$ e $<<$ não meu $>$, e do mesmo modo quanto ao que lhes é estranho?

- Inteiramente.

- Logo em qualquer cidade em que a maior parte dos habitantes estiver de acordo em aplicar estas expressões $<<$ meu $>$ e $<<$ não meu $>$ à mesma coisa - será essa a mais bem organizada?

__ Sim, e muito (PLATÃO, 1949, 462 b-c).
}

Por sua vez, contra o ideal proposto por Platão (1949) da mais completa unidade possível de toda a sociedade, Aristóteles (1985) defende um conceito geral de que sem pluralidade não há cidade (ARISTÓTELES, 1985, 1261a). Para ele, “a cidade é por natureza uma pluralidade. [...] A cidade não é constituída somente de numerosos seres humanos, mas é também composta de seres humanos especificamente diferentes" (ARISTÓTELES, 1985, 1261b). Assim, ressalta que a unidade da cidade não seria uma unidade entre coisas idênticas, mas uma unidade feita de uma pluralidade de membros entre si irredutíveis. Em suas palavras, “[...] mesmo que ela continue a ser uma cidade, por estar próxima do ponto em que deixaria de existir como tal ela seria uma cidade pior, como se a harmonia fosse reduzida a uma nota só ou o ritmo no verso a único pé” (ARISTÓTELES, 1985, 1264a). Assim, considerando essa 
pluralidade, imprescindível, segundo o filósofo, para a existência da cidade, defende Aristóteles (1985) a necessidade da propriedade privada.

Para ele, a propriedade privada estaria apta a promover virtudes como responsabilidade e prudência. O homem, preocupado com seu próprio interesse, dedicar-se-ia ao seu "negócio pessoal", progredindo. Desse modo, defende o autor as vantagens de os bens serem comuns quanto ao uso, porém possuídos como propriedade privada, "pois os bens devem ser comuns em certo sentido e privados de um modo geral” (ARISTÓTELES, 1985, 1263a).

\begin{abstract}
A administração de bens, dividida entre os respectivos possuidores, não provocará queixas recíprocas, e eles crescerão porque cada um se dedicará aos mesmos como um negócio pessoal, só seu; por outro lado, as qualidades dos cidadãos farão com que "os bens dos amigos sejam comuns", como diz o provérbio, "quanto ao uso". [...]É obviamente melhor, portanto, que a propriedade seja privada, mas que o uso seja comum, e preparar os cidadãos para este sistema é a tarefa específica do legislador.Há também uma diferença indizível, em termos de prazer, quando uma pessoa sente que um bem é exclusivamente seu, pois o instinto generalizado de amor próprio certamente não é uma vaidade, e sim um sentimento natural, embora o egoísmo seja censurado com razão [...]. Acresce-se que fazer favores e prestar assistência a amigos ou hóspedes ou companheiros é um grande prazer, e isto só é possível quando se dispõe de bens próprios. Estas vantagens são perdidas por aqueles que levam a extremos a unificação da cidade [...] (ARISTÓTELES 1985, $1263 \mathrm{a}-\mathrm{b})$.
\end{abstract}

Aristóteles (1985) chega a relacionar as ideias de propriedade e liberdade, e a contribuição da propriedade para que alguém seja considerado um "homem livre", e, por conseguinte, apto ao exercício da cidadania. Para Aristóteles (1985), ser livre seria pertencer a si mesmo, ser dono de si, diferentemente do escravo, que, por natureza, seria propriedade de outra pessoa. Essa visão acerca da condição do escravo foi estendida, inclusive, à parte mais miserável de trabalhadores, que, considerando sua degradação e suas necessidades mais básicas, não poderiam participar da política como homens livres. Assim, Aristóteles (1985) concluiu que "a melhor forma de cidade não deverá admitir os artífices entre os cidadãos, se forem admitidos nossa definição de qualidades do cidadão não se aplicará a cada cidadão, nem a cada homem livre como tal, mas somente àqueles isentos de atividades servis" (ARISTÓTELES, 1985, 1278a).

\title{
2.1.2 São Tomás de Aquino: o bem comum acima do bem particular
}

Na segunda metade do século XIII, em um resgate ao pensamento grego, Aquino (2005) revela seu entendimento de que a natureza humana age em direção a um fim. Esse fim, porém, não se restringe à realização do homem na cidade ou à perfeição do Estado. Para o 
autor, o homem não vive apenas para a polis, mas para um destino superior e transcendente: o novo céu e a nova terra. A lei da sociedade deveria, então, voltar-se à felicidade comum, permitindo a realização dos cidadãos considerados no corpo social como um todo.

Sendo o fim último da vida humana a felicidade ou a beatitude (cujo objeto é o sumo bem, soberano e infinito - Q.2, art. VIII), há de por força, a lei dizer respeito, em máximo grau, à ordem da beatitude. Demais a parte ordenando-se para o todo, como o imperfeito para o perfeito; e sendo cada homem parte da comunidade perfeita, necessária e propriamente, há de a lei dizer respeito à ordem para a felicidade comum (AQUINO, 2005, q. 90, a.2).

Aquino (2005) ressalta que a sociedade tem um valor em si, permitindo que o homem desenvolva suas qualidades e realizando, assim, "a perfeição máxima da espécie" (AQUINO, 2005, q. 50, a.4). A partir dessa ideia, fundamenta a subordinação moral do indivíduo à sociedade, a superioridade metafísica e moral do corpo social sobre o individual, do bem comum sobre o bem particular.

A sociedade desfruta, pois, de uma superioridade ontológica sobre o indivíduo. É
graças a ela, com efeito, que o homem pode conservar-se, e expandir as fontes de sua
natureza; o homem necessita do concurso da sociedade para ser plenamente homem.
É graças a ela ainda que o homem pode desenvolver suas qualidades especiais e
individuais como artesão, patrão, magistrado, homem político. Em uma palavra, a
sociedade, na sua complexidade, realiza a perfeição máxima da espécie. Ela tem,
pois, valor em si e por si; 'Ela é soberanamente digna de ser amada', e seu bem,
sendo o bem da espécie, a coloca acima do bem dos indivíduos (AQUINO, 2005, p.
50, a.4).

Percebe-se, assim, em Aquino (2005), que a superioridade do todo social existe na medida em que proporciona às partes condições de, em conjunto, alcançar a realização da espécie do modo mais perfeito. Por conseguinte, a autoridade social, enquanto representante desse todo, não pode exigir subordinação naquilo que contrarie a ordem natural das partes relativamente aos fins a que se destinam. Dessa forma, para ele, as leis injustas são "antes, violências que leis" e, dessa forma, "não obrigam no foro da consciência" (AQUINO, 2005, q. 96, a.4).

Essa visão acerca da importância do corpo social em Aquino (2005) reflete a forma como o autor enxerga a propriedade, estabelecendo a existência de uma dupla atribuição quanto à relação do homem com os bens exteriores: de um lado, a de gerir e dispor dos bens e, de outro, a de usá-los.

No que diz respeito à primeira atribuição, tem o homem o poder de adquirir bens e distribuí-los, sendo lícito, portanto, que possua alguma coisa como própria. Trata-se de um 
princípio fundamental à vida humana por três razões. Primeiro, porque, segundo ele, o indivíduo é mais solícito em administrar o que lhe pertence do que aquilo que é comum a todos. Segundo, as coisas humanas são mais bem cuidadas quando cada um emprega o seu cuidado em administrar uma coisa determinada. Em terceiro lugar, o autor coloca que, quando cada um cuida do que é seu, fazendo-o de maneira mais satisfatória, estabelece-se a paz entre os homens, considerando que os conflitos surgem mais frequentemente onde não há divisão das coisas possuídas (AQUINO, 2005).

Nesse sentido, Aquino (2005), adotando o entendimento defendido por Aristóteles (1985), assegura, consoante a prudência, a necessidade e a importância da propriedade privada, a fim de que seja alcançado o maior benefício para o bem comum, orientando os bens para a ordem, eficiência, segurança, paz e para os valores instrumentais da moderna liberdade.

A segunda atribuição que compete ao homem em relação aos bens exteriores é quanto ao uso deles. "Sob esse aspecto, o homem não deve ter as coisas exteriores como próprias, mas como comuns, neste sentido que, de bom grado, cada um as partilhe com os necessitados" (AQUINO, 2005, q.66, a.2). O direito de uso da propriedade privada, portanto, para o autor, deve estar em consonância com o bem estar da comunidade, à qual o homem está subordinado. Desse modo, a principal exigência da justiça _ de dar a cada um o que é seu _, enseja que "os bens temporais outorgados por Deus ao homem são, certamente, de sua propriedade; o uso, ao revés, deve ser não somente seu, senão também de quantos possam sustentar-se com o supérfluo dos mesmos" (AQUINO, 2005, q. 32, a.5).

Assim, no período medieval, Aquino (2005) dá continuidade à associação estabelecida pelos filósofos gregos entre propriedade e virtude, inovando, contudo, ao defender que não apenas os ricos têm obrigações morais de agir generosamente, mas também os pobres têm direitos em face dos ricos.

Desse modo, para Aquino (2005) nenhuma divisão de recursos baseada na lei humana pode prevalecer sobre as necessidades relacionadas à miséria, seguindo a ordem natural estabelecida pela "Providência Divina", segundo a qual as "coisas inferiores" destinam-se a socorrer as necessidades dos homens (AQUINO, 2005).

Percebe-se, assim, que os princípios da filantropia e assistência de bem-estar humanitária surgem para Aquino (2005) não como um aditamento a uma teoria de governo, mas, sim, como uma característica da propriedade privada. 
2.1.3 Hobbes e Hume: a propriedade enquanto criação humana

Destaca Waldron (2012) que, no início do período moderno, os filósofos voltaram sua atenção para a forma de instituição da propriedade. Tanto Hobbes (1974) como Hume (2009) defenderam que tratar-se-ia de um produto artificial, fruto da criação humana. Para Hobbes (1974), a propriedade seria produto de uma criação do Estado soberano, enquanto para Hume (2009), seria algo convencionado pelos membros da sociedade, a fim de atribuir estabilidade à posse de bens externos e permitir que cada um desfrute daquilo que possa conseguir por seu trabalho ou, mesmo, por sorte (HUME, 2009, p. 530).

Segundo o entendimento de Hobbes (1974), sendo o estado de natureza um estado de guerra de todos contra todos, caracterizado pela igualdade originária dos homens em não reconhecer limites à sua liberdade individual, não pode existir aí propriedade. Para ele, “[...] onde não há Estado conforme já se mostrou, há uma guerra perpétua de cada homem contra seu vizinho, na qual portanto cada coisa é de quem apanha e conserva pela força, o que não é propriedade nem comunidade, mas incerteza" (HOBBES, 1974, p. 85). Consequentemente, para que seja possível assegurar a propriedade, é preciso que haja a limitação da liberdade individual originária de cada homem (HOBBES, 1974).

Assim, entende Hobbes que "[...] a introdução da propriedade é um efeito do Estado [...]. Bem os sabiam os antigos que chamavam 'nómos' ( quer dizer, distribuição), ao que nós chamamos lei , e definiam a justiça como a distribuição a cada um do que é seu" $(1974$, p. 85). As regras a respeito da propriedade, portanto, seriam, para ele, fruto da autoridade, esta reconhecida do soberano, cujos comandos podem garantir a paz, tornando a sociedade segura para os homens embarcarem em atividades sociais e econômicas que ultrapassam a capacidade que possuem de se proteger usando sua própria força individual (HOBBES, 1974).

Nota-se, pois, conforme destaca Waldron (2012), que já nas observações de Hobbes a visão da propriedade levanta problemas sobre as bases gerais da organização social.

Por sua vez, Hume (2009) destaca que a principal perturbação da sociedade se deve aos bens externos e à mobilidade e facilidade com que se transmitem de uma pessoa a outra, $\mathrm{o}$ que levou os homens a "buscar um remédio que ponha esses bens, tanto quanto possível, em pé de igualdade com as vantagens firmes e constantes da mente e do corpo" (HUME, 2009, p. 529). Para ele, isso só possível por um único meio: “por uma convenção em que participem todos os membros da sociedade, para dar estabilidade à posse desses bens externos, 
permitindo que gozem pacificamente daquilo que puderam adquirir por seu trabalho ou boa sorte" (HUME, 2009, p. 529-530).

Para Hume (2009), do mesmo modo que a soberania não se legitima pela consideração de uma origem do Estado nas leis da natureza, também a justificação da propriedade deve ser buscada nas condições da vida na sociedade.

Quando os homens descobrem pela experiência que o livre exercício de seu egoísmo e de sua generosidade limitada os torna totalmente incapacitados para a sociedade; e ao mesmo tempo, observam que a sociedade é necessária para a satisfação dessas próprias paixões são naturalmente levados a se submeter à restrição de regras que possam tornar seu comércio mais seguro e cômodo (HUME, 2009, p. 539).

Assim, segundo o autor, a fundamentação para tal instituição seria o que chama de "posse estável", assinalando que a regra quanto à estabilidade da posse não apenas é útil como é "absolutamente necessária à sociedade humana” (HUME, 2009, p. 542).

Hume (2009) sugere que as razões que permitem que bens particulares devam ser atribuídos a pessoas particulares não são derivadas de uma utilidade ou vantagem que uma pessoa determinada possa extrair de um bem específico, uma vez que essa relação pode ser comum a várias pessoas ao mesmo tempo, estando sujeita a inúmeras controvérsias. Segundo o autor, a regra geral de que a posse deve ser estável não se aplica por meio de juízos particulares, voltando-se justamente para eliminar situações de discórdia, o que não seria alcançado "se nos fosse permitido aplicar essa regra diferentemente em cada caso, de acordo com a utilidade particular que pudéssemos descobrir em tal aplicação" (HUME, 2009, pp. 542-543).

\footnotetext{
Como ilustração, proponho o seguinte exemplo. Primeiramente, considero os homens em sua condição selvagem e solitária; e suponho que, sensíveis aos sofrimentos decorrentes desse estado, e prevendo as vantagens que resultariam da sociedade, eles busquem a companhia uns dos outros, oferecendo sua mútua proteção e assistência. Suponho, também, que esses homens são dotados de tal sagacidade que percebem imediatamente que o maior impedimento a esse projeto de sociedade e parceria está na avidez e no egoísmo de seu temperamento natural; para remediar tal coisa, formam uma convenção para a estabilidade da posse e para sua mútua restrição e abstenção. Bem sei que esse modo de proceder não é inteiramente natural; mas estou aqui apenas supondo que essas reflexões se formam de uma só vez, quando, na verdade, elas nascem pouco a pouco imperceptivelmente. Além disso, é bem possível haver diversas pessoas que, tendo sido separadas, por diferentes acidentes, das sociedades a que antes pertenciam, vejam-se obrigadas a formar entre si uma nova sociedade; e, neste caso, sua situação é exatamente como a que descrevi acima (HUME, 2009, p. 542).
}

O filósofo complementa que reconhece a dificuldade da situação narrada, considerando que, num primeiro momento, deve ser designado o que pertence a cada pessoa para que, então, 
seja possível alcançar a "constância" da posse. Todavia, segundo ele, essa dificuldade não representa um obstáculo intransponível.

É evidente que sua primeira dificuldade nessa situação, após a convenção geral para
o estabelecimento da sociedade e para a constância da posse, é saber como separar
seus bens e designar a cada um sua porção particular, de que deverá usufruir
inalteradamente dali em diante. Mas essa dificuldade não os deterá por muito tempo.
Imediatamente deve ocorrer a esses homens, como o expediente mais natural, que
cada qual continue a gozar daquilo que possui no presente, e que a propriedade ou
posse constante deve se unir à posse imediata. O costume não apenas tem o efeito de
nos acomodar às coisas de que usufruímos por muito tempo; gera também em nós
uma afeição por elas, de modo que acabamos preferindo essas coisas a outros
objetos, talvez mais valiosos, porém menos conhecidos. Aquilo que há muito está
sob nossos olhos, e tem sido freqüentemente usado em nosso benefício, é isso que
mais relutamos em abandonar; mas podemos facilmente viver sem os bens de que
nunca usufruímos e a que não estamos acostumados. É evidente, portanto, que os
homens assentiriam facilmente a esse expediente, ou seja, que todos continuem a
gozar daquilo que possuem no presente; e é por essa razão que estariam tão
naturalmente de acordo com essa solução (HUME, 2009, p. 543-544).

Assim, Hume (2009) destaca que um dos maiores impedimentos ao estabelecimento da sociedade é justamente o fato de o bem ser externo e cambiável, o que leva os homens, "por um acordo geral, expresso ou tácito" a restringirem os direitos uns dos outros por meio de regras de justiça e equidade (HUME, 2009, p. 544-545).

Para o filósofo, seria absurdo imaginar que é possível pensar a propriedade sem compreender plenamente a natureza da justiça, que deriva de convenções humanas, "estabelecidas quando os homens perceberam as desordens que resultam quando seguem seus princípios naturais e variáveis" (HUME, 2009, p. 572). Nesse sentido, segundo o autor, a origem da justiça explica a propriedade, sendo que o mesmo artifício dá origem a ambos (HUME, 2009, p. 572).

\subsubsection{Locke: a propriedade e o trabalho}

Ao contrário de Hobbes (1974) e Hume (2009), Locke (1994) entendia que a propriedade teria sido instituída em um estado de natureza, longe de convenções sociais ou decisões políticas. Quanto à divisão desigual da propriedade, após a dotação comum a todos os homens conferida por Deus, Locke (1994) deu uma conotação moral à legitimidade da apropriação unilateral. Para ele, considerando que cada um guarda a propriedade de sua própria pessoa, "o trabalho de seu corpo e a obra produzida por suas mãos são propriedade sua" (LOCKE, 1994, p. 42). 
[...] Sempre que ele [o homem] tira um objeto do estado em que a natureza o colocou e deixou, mistura nisso o seu trabalho e a isso acrescenta algo que lhe pertence, por isso o tornando sua propriedade. Ao remover este objeto do estado comum em que a natureza o colocou, através de seu trabalho adiciona-lhe algo que excluiu o direito comum dos outros homens. Sendo este trabalho uma propriedade inquestionável ao trabalhador, nenhum homem, exceto ele, pode ter o direito ao que o trabalho lhe acrescentou, pelo menos quando o que resta é suficiente aos outros, em quantidade e em qualidade (LOCKE, 1994, p. 42).

Dessa forma, para Locke (1994), o trabalho aparece como o ato legitimador da apropriação, pelos indivíduos, daqueles bens que originariamente pertenciam a todos os homens, em comum, no seio da natureza. Segundo ele, assim como os frutos colhidos ou os animais selvagens que nela subsistem, a terra, em si, também é adquirida _limitada e separada do bem comum _ a partir do trabalho. "A superfície da terra que um homem trabalha, planta, melhora, cultiva e da qual pode utilizar os produtos, pode ser considerada sua propriedade" (LOCKE, 1994, p. 43-44). O trabalho, segundo ele, seria um comando de Deus, e o indivíduo que, "em obediência a este comando divino, se tornava senhor de uma parcela de terra, a cultivava e a semeava, acrescentava-lhe algo que era sua propriedade, que ninguém podia reivindicar nem tomar dele sem injustiça” (LOCKE, 1994, p. 44).

Assim, para o autor, a propriedade do trabalho desenvolve importância maior que a comunidade da terra, uma vez que o trabalho estabeleceria a diferença de valor, melhorando o bem, até então comum: "basta considerar a diferença entre um acre de terra plantada com fumo ou cana, semeada com trigo ou cevada, e um acre da mesma terra deixado ao bem comum, sem qualquer cultivo" (LOCKE, 1994, p. 46).

Em sua reflexão, Locke (1994) acrescenta que aquele que cultiva a terra, ou melhor, apropria-se do bem com o seu trabalho, não diminui a reserva comum da humanidade, mas, ao contrário, contribui para seu crescimento. Segundo ele, a apropriação pelo trabalho, ainda que de todos os bens naturais, não ensejaria risco de causar dano aos outros, "pois a mesma abundância permanecia à disposição de qualquer um que utilizasse a mesma indústria" (LOCKE, 1994, p. 45).

[...] Pois as provisões que servem para o sustento da vida humana, produzidas por um acre de terra cercado e cultivado, são dez vezes maiores que aquelas produzidas por um acre de terra de igual riqueza, mas inculta e comum. Por isso, pode-se dizer que aquele que cerca a terra e retira de dez acres uma abundância muito maior de produtos para o conforto de sua vida do que retiraria de cem acres incultos, dá na verdade noventa acres à humanidade. Pois graças ao seu trabalho, dez acres lhe dão tantos frutos quanto cem acres de terras comuns. Eu aqui estimo o rendimento da terra cultivada a uma cifra muito baixa, avaliando seu produto em dez para um, quando está muito mais próximo de cem para um. Porque eu gostaria que me respondessem se, nas florestas selvagens e nas terras incultas da América, 
abandonadas à natureza sem qualquer aproveitamento, agricultura ou criação, mil acres de terra forneceriam a seus habitantes miseráveis uma colheita tão abundante de produtos necessários à vida quanto dez acres de terra igualmente fértil o fazem em Devonshire, onde são bem cultivadas? (LOCKE, 1994, p. 45).

Percebe-se, nesse sentido, que, conforme assinala Waldron (2012), a importância do entendimento de Locke (1994) para a justificação da propriedade privada está, justamente, na forma como ele combina a estrutura de uma teoria da primeira ocupação com a percepção do significado moral substantivo do trabalho.

Assim, embora Locke (1994) tenha utilizado parte da lógica da primeira ocupação de autores cuja teoria baseia-se na ideia de que o primeiro usuário humano de um recurso natural distingue-se dos demais por não ter desalocado ninguém para se apropriar do recurso, o que importava para Locke (1994) era se a terra era cultivada ou utilizada de forma produtiva, acrescentando que a apropriação pelo trabalho produtivo aumenta a quantidade de bens disponíveis na sociedade (WALDRON, 2012).

2.1.5 Kant: propriedade, vontade e ação humana

O trabalho de Kant (2003) a respeito da propriedade é menos conhecido do que o de Locke (1994) e considerado mais abstrato e formal (WALDRON, 2012). Assim como Locke (1994), Kant (2003) elabora um conceito metafísico de propriedade, estabelecendo, porém, uma conexão geral entre propriedade e ação humana, de modo a defender que haveria uma afronta a essa ação, e, assim, à personalidade humana, se algum sistema não permitisse a utilização de objetos úteis (WALDRON, 2012).

Para Kant (2003), o estado de natureza seria uma ideia não necessariamente de injustiça _ "de tratar-se mutuamente apenas em termos do grau de força que cada um tem" (KANT, 2003, §44, p. 154)_, mas de ausência de justiça, no sentido de ausência de um juiz competente para decidir os casos controvertidos, em que há disputa de direitos. Nesse estado caracterizado por Kant (2003), não obstante seja possível que uma pessoa adquira uma coisa exterior por ocupação ou por contrato, “essa aquisição permanecerá apenas provisória, enquanto não encerra a sanção da lei pública, uma vez que não é determinada pela justiça (distributiva) pública e assegurada por uma autoridade que torne efetivo esse direito" (KANT, 2003, p. 155).

Dessa forma, segundo Kant (2003), tanto no estado de natureza, quanto no estado civil, existe o direito de aquisição das coisas exteriores. Entretanto, no estado civil, estão presentes 
as condições necessárias para aplicar as leis conforme a justiça distributiva e para transformar, assim, o provisório em peremptório.

\begin{abstract}
$\mathrm{Na}$ hipótese de nenhuma aquisição ter sido reconhecida como jurídica, mesmo em caráter provisório, antes do ingresso na condição civil, a condição civil ela mesma seria impossível, pois no que toca à sua forma, leis que concernem ao que é meu ou teu no estado de natureza contêm a mesma coisa que prescrevem na condição civil, porquanto a condição civil é pensada somente por conceitos racionais puros. A única diferença é que a condição civil proporciona as condições sob as quais essas leis são aplicadas (em consonância com a justiça distributiva). Assim, se os objetos externos não fossem sequer provisoriamente meus ou teus, no estado de natureza não haveria também quaisquer deveres de direito com relação a eles e, portanto, nenhum comando para abandonar o estado de natureza (KANT, 2003 , p. 155).
\end{abstract}

Kant (2003) diferencia os direitos, enquanto faculdades (morais, conforme ressalta), como inatos ou adquiridos. O direito adquirido pressupõe um ato, já o direito inato "pertence a todos por natureza" de forma imediata e natural (KANT, 2003, p. 83). Para o autor, o único direito natural pertencente a todos os homens em virtude da humanidade é "a liberdade (a independência de ser constrangido pela escolha alheia), na medida em que pode coexistir com todos os outros de acordo com uma lei universal" (KANT, 2003, p. 83). Vinculada e mesmo compreendida na liberdade está a igualdade inata, que o autor identifica como a independência: não ser obrigado por outros, senão na medida do que se pode os obrigar reciprocamente, sendo, pois, a "qualidade do homem de ser seu próprio senhor" (KANT, 2003, p. 84).

O "meu" e o "teu" são pensados por Kant (2003) como podendo ser interiores ou exteriores, correspondendo à diferenciação entre o direito inato e o direito adquirido. "O que é inatamente meu ou teu também pode ser qualificado como o que é internamente meu ou teu (meum vel tuum internum), pois o que é externamente meu ou teu tem sempre que ser adquirido" (KANT, 2003, p. 83). Assim, o direito adquirido, no sentido colocado por Kant (2003), por não se tratar de algo interno e pressupor um ato jurídico, apresenta maiores dificuldades de fundamentação e, portanto, requer uma análise mais detalhada.

Kant (2003) entende a posse como a condição subjetiva da possibilidade do uso em geral. "É juridicamente meu (meunm iuris) aquilo com que estou de tal forma ligado que o seu uso por parte de outrem sem o meu consentimento me prejudicaria” (KANT, 2003, p. 91). Nesse ponto, para tentar melhor esclarecer o pensamento kantiano a respeito da propriedade, revelam-se oportunas as observações de Terra (1983):

Kant não faz a mesma distinção entre posse (Besitz) e propriedade (Eigentum) estabelecida atualmente, onde a noção de posse indica a situação de detenção, do 
domínio do fato e a noção de propriedade indica a situação jurídica de domínio sobre algo. Pode-se dizer com Luf, que Kant não distingue "com precisão posse e propriedade" (Luf, 1978, p. 81); por isto fala-se em geral tanto da teoria kantiana da posse quanto da teoria kantiana da propriedade. No Kant Lexikon de Eisler, na palavra Besitz encontra-se apenas a indicação para que se veja Eigentum, apesar de Kant usar com mais frequiência a primeira que a segunda. A concepção kantiana de posse abrange tanto o que se entende atualmente por posse quanto o que se entende por propriedade, a distinção sendo feita no âmbito da própria noção de posse (TERRA, 1983, p. 115).

Kant (2003), então, faz a distinção entre posse empírica e posse jurídica, ou inteligível, entendendo que "a forma de ter alguma coisa externa como o que é meu consiste numa ligação meramente jurídica da vontade do sujeito com aquele objeto de acordo com o conceito de posse inteligível, independentemente de qualquer relação com ele no espaço ou no tempo" (2003, p. 99). A dedução do conceito de uma posse não empírica funda-se no postulado jurídico da razão prática: é um dever de direito agir em relação a outro de tal maneira que o que é exterior (útil) possa ser também o seu de alguém (KANT, 2003, p. 96-97).

O conceito jurídico de posse, destaca Kant (2003), embora não seja um conceito empírico, dependente de condições espaço-temporais, detém realidade prática, ou seja, "tem que ser aplicável a objetos da experiência, cujo conhecimento depende dessas condições" (2003, p. 98).

Nesse sentido, retoma-se as observações de Terra (1983) sobre a doutrina kantiana da propriedade, que coloca que, segundo o entendimento de Kant, para que alguém possua uma maçã, por exemplo, não é preciso tê-la em sua mão, o "ter" independe de condições de espaço e tempo, mas sua realidade é prática, relaciona-se à validade das ações humanas, mais especificamente, das relações humanas com os objetos exteriores entendidos somente como algo distinto de cada um, "podendo ser uma coisa, uma promessa ou outra pessoa" (TERRA, 1983, p. 119).

Assim, Kant (2003) entende que a razão prática implica que a posse separe-se da aparência de posse, tratando-se de uma relação intelectual com o objeto, em que a pessoa tem o controle sobre ele e o utiliza de modo que não prejudique a liberdade de outrem.

Direi, portanto, que possuo um campo, ainda que esteja num lugar completamente diferente de onde estou realmente, pois estamos falando aqui somente de uma relação intelectual com um objeto, na medida em que o tenho sob controle (o conceito de posse do entendimento independente de determinações espaciais) e o objeto é meu porque minha vontade de usá-lo como me agrade não entra em conflito com a lei da liberdade externa. Aqui a razão prática requer que pensemos a posse separada desse objeto de minha escolha na aparência (ocupando-o), pensá-la não em termos de conceitos empíricos. Nisto está baseada a validade de tal conceito de posse 
(possessio noumenon), como uma legislação que é válida para todos, pois essa legislação está envolvida na expressão "este objeto externo é meu”, visto que por ela uma obrigação é estabelecida sobre todos os outros, que de outra maneira não teriam de se absterem do uso do objeto (KANT, 2003, p. 99).

Afirma, portanto, que a posse deve ser enxergada como uma posse inteligível, consistente em uma relação jurídica que independe de qualquer relação do objeto no espaço e no tempo.

\begin{abstract}
Assim, a forma de ter alguma coisa externa como o que é meu consiste numa ligação meramente jurídica da vontade do sujeito com aquele objeto de acordo com o conceito de posse inteligível, independentemente de qualquer relação com ele no espaço e tempo. Não é porque ocupo um lugar sobre a Terra com meu corpo que este lugar é alguma coisa externa que é minha (pois concerne somente à minha liberdade externa, daí somente a posse de mim mesmo, não uma coisa externa a mim, de modo que é apenas um direito interno). É meu se eu ainda o possuir, embora o tenha abandonado por outro lugar; somente então é meu direito externo envolvido (KANT, 2003, p. 99).
\end{abstract}

Observa-se que Kant (2003) vislumbra na posse não somente uma relação com o objeto, mas uma relação entre pessoas, em que são criados direitos e obrigações recíprocos. Por conseguinte, Kant (2003) assinala que apenas uma vontade comum seria capaz de garantir a todos que os limites da posse de cada um serão respeitados. Todavia, destaca o autor, "a condição de estar submetido a uma legislação externa geral (isto é, pública) acompanhada de poder é a condição civil. Conclui-se que apenas numa condição civil pode alguma coisa externa ser minha ou tua" (KANT, 2003, p. 101).

Dessa forma, Kant (2003) aborda a exigência da instituição de um estado jurídico, em que haja um poder público, para que seja possível ter algo exterior como seu de forma definitiva. $\mathrm{O}$ autor coloca que a posse anterior à condição civil, e em preparação desta, deve se basear em uma lei da vontade comum, "posse esta que, por conseguinte, se harmoniza com a possibilidade de uma tal condição, é posse provisoriamente jurídica, enquanto a posse encontrada numa condição civil real seria posse definitiva" (KANT, 2003, p. 102). Assim, a instituição do estado jurídico, do estado civil, está intimamente ligada à necessidade da garantia da propriedade.

Quanto ao problema da aquisição originária, a teoria de Kant envolve a retomada e reformulação de noções de outros filósofos modernos, sobretudo as de Grotius e Locke, conforme destaca Terra (1983, p. 125). 
Num primeiro momento ${ }^{2}$, conforme ressalta Terra (1983), Kant (1764 apud TERRA, 1983), parte do pensamento de propriedade na perspectiva aberta por Locke (1994), tendo como ponto de partida, a propriedade da própria pessoa. Assim, a propriedade do corpo e sua relação com os objetos externos permitiriam a passagem para a propriedade desses objetos. Desse modo, nesse primeiro momento, Kant (1764 apud TERRA, 1983) também via no trabalho do homem a possibilidade de transformação das coisas de acordo com a sua vontade. Entretanto, vale ressaltar que, diferentemente de Locke, a noção kantiana de trabalho adquire função de crítica social, vinculada à apropriação também no presente (TERRA, 1983).

Terra (1983) observa, ainda, que, também em sentido diverso do pensamento de Locke, Kant (1764 apud TERRA, 1983) entendia que haveria um acordo tácito entre os homens, considerando que quando o homem indica algo como sendo seu, promete respeitar a propriedade dos outros como ele quer que a sua seja respeitada. Nesse momento, para Kant (1764 apud TERRA, 1983), o fundamental na apropriação não seria a mistura do trabalho com o objeto, mas o reconhecimento de que a apropriação funda-se num ato da vontade. Assim, enfatizava que a transformação do objeto seria expressão do arbítrio, o que fazia com que a apropriação se fundamentasse na liberdade (TERRA, 1983, p. 129).

Posteriormente, Terra (1983) observa que Kant (2003), em A Metafísica dos Costumes, passa a adotar a doutrina de Grotius (apud TERRA, 1983) de uma maneira própria, alterando, ainda, profundamente, a noção que possuía de trabalho (TERRA, 1983, p. 131).

Desse modo, nesse segundo momento, Kant (2003) passa, então, a ver na ocupação o modo de aquisição originária, chegando a afirmar que o trabalho do solo não é necessário para sua aquisição. As modificações que o trabalho proporciona "são apenas acidentes, não constituem o objeto de posse direta e podem ser incorporados às posses do sujeito apenas na medida em que a substância já seja reconhecida como sua” (KANT, 2003, p. 110). E, assim, complementa que, no que diz respeito à primeira aquisição, "desenvolver a terra não passa de um signo externo de tomada de posse, o qual pode ser substituído por muitos outros signos que custam menos esforço" (KANT, 2003, p. 110).

A possibilidade da aquisição originária pela ocupação, ou seja, por um ato unilateral de vontade, decorre, para Kant (2003), do postulado da razão prática. Segundo o autor, essa vontade unilateral deve estar contida em uma vontade a priori unificada para poder impor obrigações a terceiros. Isso porque, para Kant, "somente de acordo com esse princípio da

\footnotetext{
${ }^{2}$ Terra (1983) destaca que esse entendimento foi apresentado em Bemerkungen zu den Beibachtungen über das Gehfük des Schönen um Erhabenen (Observações sobre o sentimento do belo e do sublime, escrito em 1764).
} 
vontade é possível ao livre arbítrio de cada um harmonizar-se com a liberdade de todos e, portanto, possível haver qualquer direito e, assim, também possível a qualquer objeto externo ser meu ou teu" (KANT, 2003, p. 108).

Assim, entende Kant (2003) que a vontade unida _ esta que fornecerá os fundamentos jurídicos aos atos da vontade unilateral, que por si mesma não tem a possibilidade de obrigar possibilitará a propriedade privada. A esse respeito, destaca Marcuse (1972) que, "de forma inteiramente paradoxal, a propriedade comum se torna 'fundamento legal' da propriedade privada: a propriedade por todos é 'a única condição sob a qual somente é possível que eu exclua qualquer outro proprietário do uso privado da coisa [...]” (1972, p. 91). E o autor conclui: "[a]ssim, na origem da sociedade burguesa, o interesse privado e o interesse geral, o arbítrio e a coação, a liberdade e a submissão devem estar unificados" (MARCUSE, 1972, p. 91).

2.1.6 Hegel e Marx: propriedade e responsabilidade social

Destaca Waldron (2012) que a doutrina de Hegel (1997) centra-se na contribuição da propriedade para a superação e substituição da fase subjetiva da personalidade, conferindo algum tipo de realidade externa para o que seria uma ideia pura de liberdade individual. Segundo ele, as formulações de Hegel (1997), um tanto obscuras, pontua o autor, foram retomadas por idealistas ingleses, que enfatizaram a contribuição da propriedade para o desenvolvimento ético, bem como para o crescimento do senso de responsabilidade. Isso porque Hegel (1997) não pensava na propriedade como exclusivamente voltada ao desenvolvimento individual da pessoa, mas a enxergava como uma fase no desenvolvimento da responsabilidade social (WALDRON, 2012).

Conforme observa Waldron (2012), Hegel (1997) viu a liberdade incorporada na propriedade como, em última análise, uma liberdade positiva: uma liberdade para fazer escolhas racionais e responsáveis voltadas ao bem comum.

Para Hegel (1997), a personalidade é elemento inaugural e fundamental para todo o direito, demonstrando ser esse o espaço para a propriedade. O filósofo alemão parte do pressuposto da relação essencial entre a propriedade e a efetivação da liberdade dos indivíduos. Em sua concepção, a ideia de liberdade é um elemento essencial da própria atividade humana. Para Hegel (1997), a pessoa deve conferir um domínio exterior à sua liberdade a fim de existir como ideia. A propriedade seria, então, essa "esfera externa", 
necessária para que a liberdade do indivíduo possa ser efetivada, mesmo que num âmbito abstrato (HEGEL, 1997).

41. Deve a pessoa dar-se um domínio exterior para sua liberdade a fim de existir como idéia. Porque nesta primeira determinação, ainda completamente abstrata, a pessoa é a vontade infinita em si e para si, tal coisa distinta dela, que pode constituir o domínio da sua liberdade, determina-se como o que é imediatamente diferente e separável (HEGEL, 1997, p. 44).

As ideias referentes à "personalidade" e à "pessoa" assumem, portanto, um papel central em seu pensamento, uma vez que o autor estabelece que somente a uma pessoa se pode atribuir direitos, bem como define a personalidade sob a forma de momentos da autoconsciência da própria liberdade. A esse respeito, Hegel (1997) indica a existência de etapas do desenvolvimento da autoconsciência, considerando que o homem (espírito) se vê de forma sucessiva, primeiro como pessoa _ imerso na sociedade civil_, depois como sujeito moral autônomo, e, por fim, como membro de uma comunidade, condição essa possível apenas ao cidadão de um Estado racional e que pressupõe as duas outras formas anteriores de autoconsciência. Esse percurso representa, assim, o "caminho" que percorre a vontade humana, determinada, num primeiro momento, em si e, posteriormente, exteriorizada na coisa.

Assim, segundo Hegel (1997), a propriedade consiste, em primeiro lugar, na relação da vontade individual com as coisas, representando, portanto, a determinação exterior da vontade livre. Essa vontade livre, ou seja, a liberdade constitui, para ele, a substância e o destino do domínio do direito, esse o "império da liberdade realizada" (HEGEL, 1997).

4 - O domínio do direito é o espírito em geral; aí a sua base própria, o seu ponto de partida está na vontade livre, de tal modo que a liberdade constitui a sua substância e o seu destino e que o sistema do direito é o império da liberdade realizada, o mundo do espírito produzido como uma segunda natureza a partir de si mesmo (HEGEL, 1997, p. 12).

Por sua vez, Waldron (2012) destaca que, na filosofia de Marx, o entendimento de Hegel (1997) de que existem várias etapas na formação da liberdade positiva é enquadrado em termos de estágios no desenvolvimento da própria sociedade (WALDRON, 2012).

Para Marx (2004), a propriedade não é resultado da apropriação, da atividade, mas é, antes, seu pressuposto. A relação dos indivíduos com a terra, para ele, não é aquela do proprietário privado, mas é a definida pelo seu pertencer à comunidade:

(...) mas esta relação com o terreno, à terra considerada como propriedade do indivíduo que trabalha, passa por uma mediação - portanto, o indivíduo não aparece como simples indivíduo trabalhando, nesta abstração, mas tem ele, por sua 
propriedade da terra, um modo de existência pressuposto a sua atividade e que não aparece, da mesma qualidade que sua pele, seus órgãos sensoriais, que ele reproduz por certo também no processo biológico de sua própria existência, que ele desenvolve, etc., mas que por seu turno, estão pressupostos neste processo de reprodução - sua relação com a terra passa portanto ao mesmo tempo pela mediação da existência natural, mais ou menos desenvolvida historicamente, do indivíduo enquanto membro de uma comunidade - de sua existência natural como membro de uma tribo, etc (MARX, 2004, p. 422).

Em seus Manuscritos Econômico-Filosóficos, redigidos em 1844, Marx (2004) sinaliza o trabalho alienado como fundamento da propriedade privada, partindo não de um estado de natureza, mas de um fato econômico atual, no sentido de que a atividade e a produção da riqueza transformam-se em seu contrário para seu produtor. Assim, a propriedade privada, diferentemente de pura exterioridade, aparece como resultado de uma relação social que lhe é anterior (MARX, 2004).

Nesse sentido, para Marx (2004), a exteriorização de determinadas capacidades socialmente produzidas no ato de transformação da natureza em meios de existência humanos torna-se, mais que algo exterior, um exterior separado de seu efetivador. Para além da aparência do contrato, a produção e a apropriação sociais de riqueza são tidas como a expropriação do trabalhador (MARX, 2004).

No texto conhecido como Introdução de 1857, Marx (1987) observa as relações entre forma de propriedade e de produção, reconhecendo que "toda produção é apropriação da natureza pelos indivíduos por intermédio e de dentro de uma sociedade determinada" (MARX, 1987, p. 21).

A propriedade privada capitalista, na análise de Marx (1987), não representa a realização da liberdade, mas apresenta-se tão somente como uma determinada forma histórica da produção, dotada de limites e contradições que se instauram na posição simultânea do agente que opera a produção. Para Marx (1987), muito embora a produção dos indivíduos seja um ato social de apropriação da mundaneidade _ objetivamente, uma relação de apropriação das coisas_, seria "ridículo partir daí para passar de um salto a uma forma determinada de propriedade, como, por exemplo, a propriedade privada (o que, além disso supõe, igualmente, como condição uma forma oposta, a não-propriedade)" (MARX, 1987, p. 23).

Nesse sentido, o que determina a forma do capitalismo, segundo Marx (2004), seria uma relação específica na qual se cumpre a atividade produtiva entre trabalhador assalariado livre _ o "qual somente sua falta de propriedade o coage ao trabalho e à venda de trabalho" (MARX, 2004, p. 440) _ e o capitalista, o comprador da força de trabalho. Essa relação refere- 
se à troca de mercadorias por seu equivalente, da força de trabalho pelos meios de subsistência do trabalhador assalariado, na forma de dinheiro, o que, por sua vez, oculta a expropriação da riqueza produzida, mediante a apropriação da chamada "mais-valia". A apropriação privada do excedente realiza-se, então, mediante a coação da produção de um sobreproduto, representando, segundo ele, um tempo a mais de trabalho, superior ao necessário à reprodução do valor refletido no salário (MARX, 2004, p. 440-441).

Nesse contexto, afirma Marx (2004) que, diferentemente de uma interação entre pessoas livres e iguais, a troca de equivalentes ocorrida no âmbito do trabalho assalariado apresenta uma irremediável assimetria. A separação entre o agente da produção (o trabalhador livre) e as suas condições de objetivação enseja a cisão entre trabalho e propriedade. Nessa linha de raciocínio, a força de trabalho do trabalhador revela-se como uma não-propriedade, na medida em que os pressupostos objetivos de sua efetivação não lhe pertencem. Assim, coloca o autor que "este completo despojamento é a existência puramente subjetiva do trabalho destituída de toda objetividade. O trabalho como pobreza absoluta: a pobreza não como falta, mas como exclusão total da riqueza objetiva" (MARX, 2004, p. 217).

Dessa forma, assim como Platão (1949), Marx (2004) coloca que a responsabilidade social no exercício do direito da propriedade privada não é suficiente. Segundo ele, toda a trajetória para o efetivo desenvolvimento da sociedade moderna relaciona-se com o trabalho cooperativo em grande escala, num contexto de relações econômicas coletivas. Para a efetivação da plena autorrealização do trabalhador e da humanidade, seria, então, necessária a superação da propriedade privada. Como alternativa à propriedade privada capitalista, Marx (2004) defende o comunismo:

O comunismo na condição de supra-sunção (Aufhebung) positiva da propriedade privada, enquanto estranhamento-de-si (Selbstentfremdung) humano, e por isso enquanto apropriação efetiva da essência humana pelo e para o homem. Por isso, trata-se do retorno pleno, tornado consciente e interior a toda riqueza do desenvolvimento até aqui realizado, retorno do homem para si enquanto homem social, isto é, humano. Este comunismo é, enquanto naturalismo consumado = humanismo, e enquanto humanismo consumado = naturalismo. Ele é a verdadeira dissolução (Auflösung) do antagonismo do homem com a natureza e com o homem; a verdadeira resolução (Auflösung) do conflito entre existência e essência, entre objetivação e auto-confirmação (Selbstbestätigung), entre liberdade e necessidade (Notwendigkeit), entre indivíduo e gênero. É o enigma resolvido da história e se sabe como esta solução (MARX, 2004, p. 105). 
2.1.7 Uma questão filosófica conectada à realidade: a contribuição de Dagan na construção de um conceito contemporâneo de propriedade

A partir das considerações acima, é possível verificar que, independentemente da teoria que se adote quanto às bases da fundamentação da propriedade e a organização da sociedade, a ideia de propriedade carrega em si inúmeros valores, sociais e individuais. Os mais diversos posicionamentos a respeito da propriedade, conjuntamente considerados, levamnos, portanto, a refletir que o conceito não pode se resumir a uma ideia de pertencimento individual, marcado pela exclusão e exclusividade em favor do proprietário. Liberdade, igualdade, responsabilidade e justiça são, pois, noções diretamente relacionadas ao conceito.

Todavia, como assinala Waldron (2012), são breves as pesquisas a respeito das tentativas presentes na história de trazer à tona, diante da já existente má distribuição e exploração da propriedade, o sentido dos verdadeiros princípios sobre os quais um sistema ideal de propriedade privada deve repousar.

Não se pode perder de vista que os princípios a que a propriedade deve servir e os direitos que integram a noção relacionam-se, portanto, diretamente à distribuição de riqueza, à igualdade entre as pessoas e à sua liberdade. Assim, conforme já mencionado, há que se pensar em um sistema comprometido com a sociedade como um todo, conectado às mais variadas dimensões sociais, ao invés de um sistema de mercado puro da propriedade privada (WALDRON, 2012).

Como se vê_e será mais detalhadamente abordado ao longo da presente exposição _, normativamente, a propriedade serve a um conjunto de valores, tanto sociais como individuais. A pluralidade da propriedade reflete, justamente, a heterogeneidade de suas manifestações na vida real, constatação essa que assume fundamental importância na concepção proposta por Dagan (2011), que define a propriedade como um "guarda-chuva de um conjunto de instituições - instituições da propriedade - que carregam semelhanças entre si”3 (DAGAN, 2011, p. 42).

Assim, ao considerar a propriedade como instituições, o autor destaca a necessidade de que seja feita uma análise contextual e normativa das diferentes formas da propriedade, ao tempo em que assinala a importância de se pensar a concepção de forma abstrata, de sorte que

\footnotetext{
${ }^{3}$ Tradução livre de: "Property is an umbrella for a set of institutions - property institutions - bearing family resemblances" (DAGAN, 2011, p. 42).
} 
o conceito comporte em si a preocupação com a efetivação de valores sociais e, por conseguinte, com a proteção da sociedade considerada como um todo.

A proposta de Dagan (2011), portanto, permite o diálogo dos mais diversos posicionamentos a respeito da propriedade, na medida em que defende a importância tanto da forma quanto do conteúdo da concepção, ressaltando que cada instituição apresenta um equilíbrio específico entre os valores humanos presentes nas mais variadas relações envolvendo o homem e a coisa, considerando, ainda, as nuances e peculiaridades do contexto em que essas relações estão inseridas.

Entende-se, assim, como será tratado a seguir, que a concepção de Dagan (2011) possibilita que a propriedade seja reconhecida como uma importante questão filosófica, porém conectada à realidade, ou seja, que se pense a propriedade a priori, mas, ao mesmo tempo, como parte de uma abordagem socialmente estratégica voltada a atender as reais necessidades da sociedade e dos indivíduos, reconhecendo-se o papel-chave que a propriedade desempenha na busca pela justiça social.

\subsection{Propriedade: a complexidade do conceito e as dificuldades de sua definição}

Conforme destaca Grossi (2006), falar de propriedade significa recusar a absolutização da propriedade moderna, produto histórico de uma época. Ressalta o autor que o "modelo antropológico napoleônico-pandectístico", consagração de uma visão individualista e potestativa, configura apenas uma dentre as múltiplas respostas possíveis, encontradas em meio a inúmeras experiências jurídicas, do passado e do presente, ao eterno problema das relações entre homens e coisas (GROSSI, 2006, pp. 11-12). Assim, segundo Grossi (2006), a propriedade, rompendo a trama superficial das formas, relaciona-se, inevitavelmente, por um lado, a uma visão do homem do mundo; e, por outro, a uma ideologia, considerando seu estreito vínculo com interesses vitais de indivíduos e de classes (GROSSI, 2006, p. 31).

Em nosso ordenamento jurídico, constata-se que o Código Civil (BRASIL, 2002), ao retratar a propriedade em seu artigo 1.228, a define, num primeiro momento, como o direito de usar, gozar e dispor da coisa, juntamente com o direito de "reavê-la do poder de quem quer que injustamente a possua ou detenha"4 (BRASIL, 2002). Por sua vez, o parágrafo primeiro do mesmo artigo complementa o conceito, estabelecendo que a propriedade deve ser exercida

\footnotetext{
${ }^{4}$ Art. 1228, Código Civil, de 2002: "O proprietário tem a faculdade de usar, gozar e dispor da coisa, e o direito de reavê-la do poder de quem quer que injustamente a possua ou detenha” (BRASIL, 2002).
} 
de acordo com finalidades econômicas e sociais "e de modo que sejam preservados, de conformidade com o estabelecido em lei especial, a flora, a fauna, as belezas naturais, o equilíbrio ecológico e o patrimônio histórico e artístico, bem como evitada a poluição do ar e das águas" $" 5$ (BRASIL, 2002).

Observa-se que a propriedade, antes considerada um direito subjetivo absoluto, aparece na disposição do atual Código Civil (BRASIL, 2002), em consonância com a Constituição Federal (BRASIL, 1988), sob um aspecto totalmente diverso, aliando a finalidade social do direito às suas faculdades de usar, gozar e dispor. O princípio da função social da propriedade, mencionado expressamente no texto constitucional, em seu artigo 170, inciso III $^{6}$, relativiza o individualismo que marcou o tratamento da propriedade na codificação oitocentista, bem como altera sua estrutura e seu regime jurídico, atuando sobre o conceito e o conteúdo da propriedade (GONDINHO, 2000, p. 429).

A esse respeito, vale dizer que, com a Constituição Federal de 1988 (BRASIL, 1988), passa a prevalecer no ordenamento pátrio a tutela dos valores existenciais que exprimem a ideia de dignidade, em superação ao individualismo característico da ordem anterior. Nesse sentido, a dignidade da pessoa humana, estabelecida como um dos fundamentos da República Federativa do Brasil ${ }^{7}$, coloca, então, o ser humano como objetivo central do ordenamento jurídico, orientando e fundamentando o sistema, de modo que todo ele seja direcionado à sua proteção (FACHIN, 2003).

Assim, em nosso ordenamento, percebe-se que o Código Civil (BRASIL, 2002), convergindo com a Constituição Federal (BRASIL, 1988), reflete uma visão social e múltipla da propriedade, reconhecendo se tratar de um importante instrumento de concretização de valores humanos, o que se ajusta, perfeitamente, à proposição de Dagan (2011), que será abordada ao longo da presente exposição. Assim, em contraposição ao modelo individualista destacado por Grossi (2006), o diploma civilista ressalta, como visto, as finalidades econômicas e sociais a que deve servir a propriedade, sinalizando, portanto, que não se trata apenas de direitos de exclusão ou exclusividade em favor do proprietário, mas, sim, de uma

\footnotetext{
${ }^{5}$ Art. 1228, $\S 1^{\circ}$, Código Civil, de 2002: O direito de propriedade deve ser exercido em consonância com as suas finalidades econômicas e sociais e de modo que sejam preservados, de conformidade com o estabelecido em lei especial, a flora, a fauna, as belezas naturais, o equilíbrio ecológico e o patrimônio histórico e artístico, bem como evitada a poluição do ar e das águas (BRASIL, 2002).

${ }^{6}$ Art. 170, CF: A ordem econômica fundada na valorização do trabalho, tem por fim assegurar a todos existência digna, conforme os ditames da justiça social, observados dos seguintes princípios: [...] III - função social da propriedade; (BRASIL, 1988).

${ }^{7}$ Art. $1^{\circ}$, III, CF: A República Federativa do Brasil, formada pela união indissolúvel dos Estados e Municípios e do Distrito Federal, constitui-se m Estado Democrático de Direito e tem como fundamentos: [...] III - a dignidade da pessoa humana (BRASIL, 1988).
} 
noção extremamente complexa, composta por diversas estruturas e conteúdos substancialmente diferenciados.

Em linhas gerais, o termo propriedade relaciona-se às regras que regem o acesso e o controle de pessoas sobre determinados recursos, tais como a terra, bens manufaturados, meios de produção, ou, ainda, bens imateriais específicos, como, por exemplo, textos, ideias e outros produtos intelectuais.

Observa-se, entretanto, que, conforme destaca Waldron (2012), a discussão sobre o que seria a propriedade enfrenta dificuldades não apenas nas bases de justificação dessa instituição _ conforme visto, brevemente, a partir das observações trazidas no item anterior_, mas na própria definição do termo, não havendo uma unanimidade acerca do que consiste, exatamente, essa concepção.

Um reflexão comprometida, considerando os posicionamentos divergentes, sobre como deve se dar a utilização da propriedade e o que, de fato, o conceito representa assume significativa importância, uma vez que atinge diretamente a vida das pessoas, sobretudo, quando estão em jogo objetos essenciais e, ao mesmo tempo, limitados e escassos ${ }^{8}$. Mais que um direito ou uma concepção, trata-se, pois, de uma instituição social, ou, nas palavras de Grossi (2006), uma mentalidade, que reflete a visão da sociedade e os vínculos, como já mencionado, com interesses vitais de indivíduos e de classes (GROSSI, 2006, p. 31).

Ademais, a criação de um sistema de regras a respeito da propriedade faz-se necessária em qualquer sociedade, para que conflitos sejam evitados e a fim de que sejam viabilizadas a produção, a cooperação e a troca ${ }^{9}$ (WALDRON, 2012, p. 1). Portanto, nas mais diversas sociedades, verifica-se algum tipo de regramento sobre a propriedade, sendo a propriedade privada uma das possíveis formas existentes.

A respeito dos variados regimes de propriedade, Grossi (2006) faz uma interessante observação. O autor, em um "convite a relativizar noção e instituto", assinala que falar de propriedade, muitas vezes, equivale a enclausurar-se no nicho de uma cultura de

\footnotetext{
${ }^{8}$ Nesse ponto, vale lembrar que Hume (2009) chegou a sugerir que as relações de propriedade apenas fariam sentido diante de condições de escassez. Entretanto, tal como defende Waldron (2012), outros níveis de conflito são possíveis, como, por exemplo, a respeito da forma como deve ser utilizada a propriedade ou mesmo se um determinado pedaço de terra possui algum significado simbólico ou histórico, seja num contexto de escassez ou não. Exemplo disso é a propriedade intelectual, em que as regras de propriedade não estão relacionadas diretamente a um contexto de escassez, considerando que a utilização por determinada pessoa não necessariamente esgota a possibilidade de utilização por outra.

${ }^{9}$ Nas palavras de Waldron (2012): "Any society with an interest in avoiding conflict needs such a system of rules. Their importance can hardly be overestimated, for without them cooperation, production, and exchange are virtually impossible, or possible only in the fearful and truncated forms we see in 'black markets"' (WALDRON, 2012, p. 1).
} 
pertencimento individual (GROSSI, 2006, p. 5). E esse, segundo ele, "é um horizonte demasiado estreito", uma vez que "reduzir a esta dimensão a multiforme relação homens-bens tem o sentido de uma deplorável redução à miséria" (GROSSI, 2006, p. 6). Nesse sentido, traz como exemplo a propriedade coletiva ${ }^{10}$, estrutura em que a noção do "meu" jurídico perde, de certa forma, a relevância na construção da concepção.

\begin{abstract}
Pois bem, essa assim chamada propriedade coletiva, em toda sua forma, tem - em meio a mil variações, segundo os lugares, os tempos e as causas mais diferentes uma plataforma comum; e é a de ser garantia de sobrevivência para os membros de uma comunidade plurifamiliar, de ter um valor e uma função essencialmente alimentares, em que o conteúdo fundamental é um gozo condicionado do bem, com um indiscutível primado do objetivo sobre o subjetivo; primado da ordem fenomênica, que deve ser respeitado a todo custo, sobre o indivíduo; da ordem comunitária - cristalização da objetividade histórica - em relação ao indivíduo. Aqui não somente a dimensão potestativa é rarefeita ao máximo, tanto é que não se encarna jamais em um jus disponendi, mas até mesmo a própria dimensão apropriativa se destempera como vã. A apropriação aqui, no sentido tradicional do termo, cai somente indiretamente sobre o produto do fundo que serve para a sobrevivência quotidiana de um núcleo unifamiliar, mas nunca investe o fundo (GROSSI, 2006, p. 8).
\end{abstract}

Por sua vez, Waldron (2012) também recorda que não há apenas um regime possível de propriedade, ressaltando a existência dos regimes da propriedade privada, da propriedade comum e da propriedade coletiva. O primeiro regime, o da propriedade privada, que será abordado mais detalhadamente ao longo do presente estudo, liga-se à noção de um processo de tomada de decisão individual a respeito de determinado recurso. Já a propriedade comum reflete a ideia de acesso a todos, ou seja, de utilização por toda a comunidade. A propriedade coletiva, por sua vez, relaciona-se com um processo de tomada de decisão coletiva com base no interesse social, em que a sociedade, como um todo, decide a importância dos recursos e a forma como se dará sua utilização. Nesse ponto, observa-se, por oportuno, que, no caso descrito por Grossi (2006), a propriedade coletiva seria aquela titularizada por vários proprietários. Há, pois, também aqui, um processo coletivo de tomada de decisão, porém, como pode se verificar, trata-se de um regime ainda diverso daqueles evidenciados por Waldron (2012).

Vale dizer que as formas de regime de propriedade não se excluem, podendo, perfeitamente, conviver dentro do contexto social. As alternativas, portanto, na grande maioria das sociedades contemporâneas, coexistem: alguns recursos são regidos por regras de

\footnotetext{
${ }^{10} \mathrm{O}$ autor exemplifica a propriedade coletiva a que se refere como "as assim chamadas 'propriedades' comuns de consortes co-herdeiros, em que a titularidade não é nem do indivíduo nem do ente, mas da concatenação incessante das gerações dos consortes" (GROSSI, 2006, p. 8).
} 
propriedade comum (como, por exemplo, parques públicos e ruas), outros, pelo regime de propriedade coletiva (como, por exemplo, repartições públicas e bases militares) e outros, ainda, pelas regras da propriedade privada, havendo, nesse ponto, diferenças nos graus de liberdade que um proprietário privado possui de acordo com o contexto de regras de conduta vigentes (não necessariamente relacionadas de forma específica ao regramento da propriedade) (WALDRON, 2012).

No que tange, especificamente, ao regime da propriedade privada, observa-se que esse é organizado em torno da ideia de que a pessoa (física ou jurídica) que possui o objeto tem o controle sobre ele, decidindo como utilizá-lo, da maneira que melhor lhe convier. Entretanto, embora abarque um processo individual de tomada de decisões, o regime da propriedade privada enquadra-se, ainda, num conceito de sistema de regras sociais, sendo tutelado pelo Estado em face de terceiros e do próprio ente público. Nesse sentido, conforme ilustra Waldron (2012), o proprietário não é obrigado, por exemplo, a confiar em sua própria força para reivindicar seu direito de tomar decisões de interesse próprio sobre o objeto que lhe pertence. Assim, caso sua propriedade seja afetada de alguma forma, ele pode, inclusive, reclamar por proteção policial.

Percebe-se, pois, que o regime da propriedade privada, ao tempo em que mobiliza força e expensas públicas na sua proteção, permite ao indivíduo tomar decisões a respeito de recursos, muitas vezes escassos, num sentido não necessariamente relacionado às necessidades de terceiros ou, mesmo, ao bem comum. A ideia, portanto, relaciona-se, num primeiro momento, ao direito do proprietário de excluir terceiros, bem como à exclusividade que possui para determinar a agenda do recurso. Desse modo, por conjugar um regime de controle individual com um sistema de regras sociais, tutelado, portanto, pelo Estado, a propriedade privada é objeto de um constante trabalho de justificação, não havendo, conforme já mencionado, consenso a respeito, exatamente, de quais elementos, entre valores individuais e sociais, compõem o conceito (WALDRON, 2012).

Ao lado dessa conjugação de regimes, portanto, a propriedade privada, como construção humana que representa, reflete importantes valores e necessidades da sociedade, relacionando-se diretamente com princípios como distribuição de riqueza, igualdade e liberdade. Trata-se, como observou Waldron (2012), de uma "peça-chave" na sociedade, apta a assumir, pois, um relevante papel na busca da justiça social.

Desse modo, não obstante a discussão acerca de sua definição, diante da existência desses inúmeros valores subjacentes à propriedade privada e da mencionada conjugação de 
um regime de controle individual com um sistema específico de regras sociais, reconhece-se a inadequação de qualquer concepção que implique que o proprietário tenha controle absoluto sobre dado recurso, em total exclusão ao direito do restante da sociedade. Entende-se que, em face da complexidade e da dinamicidade próprias das sociedades contemporâneas, não há como prevalecer o conhecido conceito de Blackstone (2011) de propriedade enquanto "um domínio único e despótico, que permite ao proprietário exercer e reivindicar seu direito em face das outras coisas externas do mundo, em total exclusão do direito de qualquer outro indivíduo no universo" "11 (BLACKSTONE, 2011, p. 304).

O conceito blackstoniano, portanto, outrora reconhecido como a definição mais adequada do que seria a propriedade, atualmente, não traduz o real significado da concepção no contexto social.

Todavia, muito embora reconheça a inadequação do conceito mencionado, Dagan (2014) destaca que a definição delineada por Blackstone (2011) ainda possui um papel relevante na construção do conceito de propriedade. Rejeitando a proposição de que a exclusão configure a essência da concepção, Dagan (2014) vislumbra sua importância enquanto um dos componentes do que denomina de "estrutura pluralista da propriedade".

Em interessante análise, que será tratada oportunamente, o autor defende que a propriedade deve ser enxergada como um "guarda-chuva de um conjunto de instituições instituições da propriedade - que carregam semelhanças entre si"12 (DAGAN, 2011, p. 42). E, nesse sentido, para o autor, a noção blackstoniana possui um papel singular por caracterizar uma dessas instituições da propriedade, particularmente importante, em que prevalece a cuidadosa proteção da independência da esfera privada, contribuindo, assim, para o desenvolvimento pessoal e para a autonomia do indivíduo.

A objeção a estes excessos, contudo, não significa que a propriedade
blackstoniana não possua um papel relevante. Pelo contrário: a inclusão da
propriedade blackstoniana no repertório do direito de propriedade adiciona uma
opção crucial, que contribui com a autodeterminação. Ademais, a propriedade
blackstoniana apresenta-se de forma singular entre as instituições da propriedade
em sua proteção zelosa com relação à nossa independência. Protegendo os
indivíduos de reivindicações de terceiros e do poder da autoridade pública, a
propriedade não qualificada garante uma intocável esfera privada, este um pré-
requisito do desenvolvimento pessoal e da autonomia. Apesar de a independência
não ser nosso valor último, considerando que autonomia real requer

11 Tradução livre de: "That sole and despotic dominion which one man claims and exercises over the external things of the world, in total exclusion of the right of any other individual in the universe" (BLACKSTONE, 2011, p. 304).

${ }^{12}$ Tradução livre de: "Property is an umbrella for a set of institutions - property institutions - bearing family resemblances" (DAGAN, 2011, p. 42). 
autodeterminação mais do que somente independência, continua sendo um componente constitutivo da autodeterminação, possuindo, assim, valor intrínseco, mais que meramente instrumental. A independência, portanto, explica o posto único da propriedade blackstoniana, implicando que uma política liberal deve oferecer aos seus membros o domínio exclusivo que esta propriedade não qualificada representa. Isto é, eu defendo, o que faz da propriedade blackstoniana uma instituição da propriedade particularmente importante ${ }^{13}$ (DAGAN, 2014, p. 18-19).

Sobre esse importante papel desempenhado pela concepção blackstoniana de propriedade, Dagan (2014) apresenta três conclusões principais.

Em primeiro lugar, coloca que a referida noção não deve aspirar à exclusividade, mas ser vista como "parte do repertório liberal das instituições propícias à determinação pessoal do indivíduo" (DAGAN, 2014, p. 19).

Sua segunda conclusão relaciona-se ao legítimo escopo da concepção. Na medida em que a definição levantada por Blackstone (2011) tem por finalidade garantir a "soberania" dos particulares sobre fatores externos em prol de sua independência e autodeterminação, a referida concepção só pode abarcar aqueles tipos de recursos (e relações) cujo objetivo seja assegurar tais valores. Isso porque além desses direitos voltados a proteger a propriedade de ingerências externas, outras “justificações” compõem os direitos de propriedade, de modo que os direitos que repousam sobre a justificativa inerente ao conceito blackstoniano não devem ser tomados como absolutos. Nesses casos, ressalta Dagan (2014), especialmente quando a reivindicação dos "não-proprietários" referente ao acesso a determinado recurso é também importante para sua própria autodeterminação, o domínio do proprietário deve estar sujeito ao direito de entrada ou de inclusão daqueles terceiros (DAGAN, 2014, p. 19).

Finalmente, a terceira conclusão expressa pelo autor diz respeito ao fato de que a associação da propriedade blackstoniana à autonomia da pessoa significa, por sua vez, que a legitimidade dessa forma da propriedade não se relaciona a um evento específico _ diferentemente, por exemplo, do que defendia Locke (1994) ao se referir ao trabalho, ou Hegel (1997), à ocupação, mas à sua importância como tal. Essa justificação geral baseada no

\footnotetext{
${ }^{13}$ Tradução livre de: "Objecting to these excesses, however, does not mean that Blackstonian ownership has no significant role. Quite the contrary: the inclusion of Blackstonian ownership in the repertoire of property law adds a crucial option, which contributes to self-authorship. Moreover, Blackstonian ownership is singular among property institutions in its zealous protection of our independence. By shielding individuals from the claims of others and from the power of the public authority, unqualified ownership guarantees the untouchable private sphere that is a pre-requisite of personal development and autonomy. Though independence is not our ultimate value, since real autonomy requires self-authorship rather than merely independence, it is still a constitutive component of self-authorship and thus intrinsically rather than merely instrumentally valuable. Independence, then, explains the unique place of Blackstonian ownership, implying that a liberal polity must offer its members the realm of solitude that such unqualified ownership represents. This is, I argue, what makes Blackstonian ownership a particularly important property institution" (DAGAN, 2014, p. 18-19).
} 
valor em si implica que todo ser humano tem algum direito à propriedade, ou, "mais precisamente, à quantidade de propriedade em sua concepção blackstoniana necessária para sustentar sua dignidade” (DAGAN, 2014, p. 20). Assim, destaca Dagan (2014), a aplicação dos direitos dos "proprietários blackstonianos" no direito de propriedade não pode ser justificada se a lei não garantir, simultaneamente, recursos semelhantes aos "nãoproprietários" (2014, p. 19-20).

Nesse sentido, conforme mencionado, ainda que não possa ser considerada a definição adequada da propriedade privada, a concepção de Blackstone (2011) tem muito a contribuir para a construção de uma concepção contemporânea de propriedade.

Em contrapartida ao posicionamento blackstoniano, Hohfeld (1917) afirmava que os direitos de propriedade não consistiam em "um dever comum com o mesmo conteúdo em face de todos"14 (HOHFELD, 1917, p. 743). Segundo o autor, o direito de propriedade envolve múltiplos direitos e múltiplas relações de "direitos e deveres" (right-duty relations) entre inúmeras pessoas. Desse modo, a propriedade para Hohfeld (1917) é definida como um complexo agregado de direitos (ou reivindicações), deveres, privilégios, poderes e imunidades. Assim, o autor representa a ideia de propriedade a partir da metáfora do "feixe de gravetos" (bundle of sticks). Com base em alguns exemplos, ele demonstra que um proprietário de terras é investido legalmente pelos vários "gravetos" (direitos, deveres, privilégios, poderes e imunidades), em face das demais pessoas com relação à sua terra. Por sua vez, explica que, nessa concepção, as diversas classes de relações jurídicas não devem ser confundidas entre si, uma vez que a relação proveniente da propriedade expressa por um "graveto" específico é totalmente independente das demais relações.

\begin{abstract}
Em suma, $A$ passou a investir em si mesmo, no que diz respeito ao Blackacre, relações de "direito-dever", múltiplas, ou sobre a coisa, relações de "poderresponsabilidade", múltiplas, ou sobre a coisa, e relações de "imunidadeincapacidade", múltiplas ou sobre a coisa. É importante, a fim de que se tenha uma adequada visão analítica da propriedade, enxergar todos esses vários elementos no agregado. É igualmente importante, por muitas razões, que as diferentes classes da relação jurídica não sejam livremente confundidas com as outras. Os privilégios de $A$, e.g., são notavelmente independentes de seus direitos ou reivindicações contra uma determinada pessoa, e, inclusive, podem existir uns sem os outros ${ }^{15}$ (HOHFELD, 1917, p. 747).
\end{abstract}

\footnotetext{
${ }^{14}$ Tradução livre: "It is not a case of one joint duty of the same content resting on all - e.g., that B should enter on Blackacre" (HOHFELD, 1917, p. 743).

${ }^{15}$ Tradução livre de: "In short, A has vested in himself, as regards Blackacre, multital, or in rem, "right-duty" relations, multital or in rem, "power-liability" relations, and multital, or in rem, "immunity-disability" relations. It is important, in order to have an adequate analytical view of property, to see all these various elements in the aggregate. It is equally important, for many reasons, that the different classes of jural relations should not be
} 
Embora enxergue a propriedade a partir de um contexto, refletindo o que a instituição representa na vida real, também essa definição de Hohfeld (1917) é passível de críticas. Apesar de reconhecer a estrutura múltipla da propriedade, com a qual concordamos, o autor concebe o instituto unicamente como substância, a partir de um agregado, complexo e desforme, de direitos e deveres, distante, pois, de noções como estabilidade e previsibilidade, as quais também desempenham um papel importante na construção do conceito.

Quanto às relações que compõem a estrutura da propriedade, observa-se, ainda, as constatações de Honoré (1961) de que o proprietário sujeita-se, também, a proibições e limitações e que a propriedade compreende determinadas características que independem da escolha ou da vontade daquele que a possui. O referido autor chega a listar o que denomina de “incidentes padrão" da propriedade, os quais, segundo ele, podem ser considerados como ingredientes necessários à noção de propriedade, ressaltando, todavia, que, individualmente considerados, não são condições necessárias para que uma pessoa seja designada como proprietária de determinada coisa em dado sistema. Ou seja, em suas palavras, "a utilização do termo 'proprietário' estende-se a casos em que nem todos os incidentes listados estarão presentes" (HONORÉ, 1961, p. 370).

Honoré (1961), então, enumera onze "incidentes padrão", que fazem parte de um conceito ideal de propriedade: (i) o direito de possuir, como o direito de excluir outrem do uso ou dos benefícios da coisa; (ii) o direito de usar, como o direito ao gozo da coisa; (iii) o direito de gerir, como o direito de decidir como o recurso pode ser usado e por quem; (iv) o direito ao rendimento, que seria o direito sobre a renda proveniente do recurso; (v) o direito ao capital, que o autor define como o direito de alienar a coisa e a liberdade de consumi-la, gastá-la, modificá-la ou destruí-la, parcial ou inteiramente; (vi) o direito à segurança, relacionado ao direito de o proprietário manter-se nessa condição, se assim o desejar e mantiver-se solvente, tratando-se de uma imunidade de expropriação; (vii) o direito de transmissibilidade, como o direito de transmitir a propriedade a quem convier ao proprietário, ligado à noção de duração ilimitada - perpétuité - do direito de propriedade; (viii) a ausência de termo, também relacionada à ideia de perpétuité, como o incidente anterior, (ix) a proibição do uso nocivo, como um dever do proprietário de não utilizar a coisa de forma prejudicial a terceiros; $(\mathrm{x})$ a responsabilidade da execução, relacionada à possibilidade de perda da propriedade em virtude

loosely confused with one another. A's privileges, e.g., are strikingly independent of his rights or claims against any given person, and either might exist without the other" (HOHFELD, 1917, p. 747). 
de débitos do proprietário; e (xi) o caráter residual, que diz respeito a regras relativas à reversão de direitos de propriedade (1961, pp. 370-375).

Ainda quanto à complexidade da definição, Waldron (1988) questiona a razão que leva a propriedade privada a ser pensada como um conceito "indefinível”. O autor ressalta, então, três "fontes de indeterminação" ( source of indeterminacy) que estão presentes na concepção e que ensejam essa dificuldade de definição do termo (WALDRON, 1988, p. 27).

Em primeiro lugar, demonstra que a propriedade privada não é uma simples relação entre a pessoa e a coisa, ou melhor, não pode, de forma alguma, ser considerada simples, uma vez que representa uma série de relações envolvendo várias pessoas. Assim, conforme destaca Waldron (1988), a propriedade privada apresenta-se como um complexo feixe de relações (bundle of relations), que diferem, consideravelmente, entre si, em seu caráter e em seus efeitos (1988, p. 28). A partir do exemplo de uma pessoa que possui um automóvel, o autor demonstra que a propriedade sobre a coisa envolve liberdades, proibições, direitos de transmissibilidade, responsabilidades e abarca a relação, por exemplo, entre o proprietário e seus vizinhos, entre ele e a polícia e entre ele e todas as demais pessoas ${ }^{16}$.

A segunda "fonte de indeterminação" levantada por Waldron (1988) diz respeito aos diferentes tratamentos conferidos à propriedade conforme o ordenamento próprio de cada país. O autor exemplifica essa fonte de indeterminação, mencionando que nos Estados Unidos existe maior liberdade nas regras referentes à transmissibilidade da propriedade do que na Inglaterra ou na Nova Zelândia. Acrescenta que, na França, a aplicação da doutrina da legitima portio elenca um complexo diferente de testamentos, legados e herança. Diante dessa constatação, Waldron (1988) questiona se tratar-se-ia de um equívoco linguístico na tradução dos vocábulos (ou seja, a palavra francesa propriété não poderia ser traduzida como ownership, representando ideias diversas) ou se o termo "propriedade" (propriété e ownership) não abarcaria, por si só, a transmissibilidade do direito. Para o autor, muitos juristas adotam a segunda opção, entendendo que o termo "propriedade" serve apenas para indicar determinadas relações jurídicas, alguns direitos, liberdades, poderes, etc. Entretanto,

\footnotetext{
${ }^{16}$ Conforme destaca Waldron (1988), o proprietário, que, no seu exemplo, chama-se Susan, possui determinadas liberdades para utilizar fisicamente o seu automóvel (um Porsche), podendo, por exemplo, se assim lhe convier, colocar os mais diversos objetos no interior de seu veículo. Possui também direitos de transmissibilidade e direitos em face de terceiros quanto ao objeto de sua propriedade (outras pessoas não podem usar o carro de Susan, senão com sua permissão). Todavia, mesmo na condição de proprietária, Susan não possui a liberdade, por exemplo, de dirigir sem licença de motorista, ultrapassar a velocidade permitida ou incomodar terceiros, possuindo, ainda, responsabilidade pelos danos eventualmente causados ao dirigir seu carro. Ademais, o automóvel responde pelos débitos de Susan, podendo, eventualmente ser apreendido por força de alguma execução em que a proprietária figure como devedora (WALDRON, 1988, p. 27).
} 
Waldron (1988) conclui que, qualquer que seja o entendimento a respeito, é importante que se coloquem de lado os vocábulos "propriedade" e "propriedade privada" (ownership e private property) e se analise as reais relações jurídicas envolvidas em cada situação determinada (1988, p. 29).

A terceira "fonte de indeterminação" relaciona-se ao fato de que os recursos sobre os quais recai a noção de propriedade diferem tão drasticamente na teoria jurídica que parece pouco provável que um único conceito possa ser aplicado a todos eles, ainda que no âmbito de um mesmo ordenamento jurídico. Destaca Waldron (1988) que o proprietário de um automóvel difere-se do proprietário de uma determinada extensão de terra, possuindo diferentes liberdades, deveres e responsabilidades. Por sua vez, a propriedade sobre bens materiais diverge da propriedade sobre bens imateriais, como ideias e direitos autorais e assim por diante. Tal diferenciação ocorre, ainda, complementa o autor, para os diferentes tipos de proprietários, se pessoa física ou jurídica, o que irá também afetar a natureza das relações integrantes da noção de propriedade. "Mais uma vez, a palavra 'propriedade' [...] pode ser inútil e enganosa, por não poder transmitir qualquer conteúdo comum para conjuntos bastante diferentes de relações jurídicas"17 (1988, p. 30).

É possível perceber, portanto, que o termo propriedade, por si só, não fornece uma descrição exata acerca de quais são os direitos (e deveres) que lhe são inerentes, de modo a depender de fatores como quem é o proprietário (se, por exemplo, é uma pessoa jurídica), qual o recurso sobre o qual recai a propriedade e em qual contexto a relação está inserida.

A esse respeito, Waldron (2012) ressalta que até mesmo a noção de "uso exclusivo" traduz uma ideia complexa, uma vez que implica tanto a noção de que o proprietário tem liberdade de usar seu recurso como lhe convier, quanto o fato de que terceiros não podem fazer uso do objeto sem sua permissão. O proprietário tem, pois, o poder de permitir que terceiros utilizem sua propriedade, o que, por seu turno, faz surgir outros interesses e expectativas legítimas, de sorte que as diversas liberdades, direitos e poderes passem a ser divididos entre vários indivíduos. Assim, considerando o poder do proprietário de transferir seu "feixe de direitos", o sistema de propriedade privada torna-se independente e contínuo. Nesse sentido, como o sistema "autoperpétuo" que representa, uma vez estabelecida a atribuição inicial dos objetos aos proprietários, não haveria mais necessidade de a comunidade ou o próprio Estado se preocuparem com questões de distribuição: a circulação dos recursos

\footnotetext{
${ }^{17}$ Tradução livre de: 'Once again the common word 'ownership' - 'X owns the car', 'Y owns the land', 'Z owns the copyright' - may be unhelpful and misleading, for it cannot convey any common content for these quite different bundles of legal relations" (WALDRON, 1988, p. 30).
} 
dar-se-ia da forma determinada pelos seus proprietários e, assim, sucessivamente (WALDRON, 2012).

Como uma problemática consequência desse raciocínio, a riqueza pode ou não manterse concentrada nas mãos de poucas pessoas, não fazendo parte da lógica da propriedade privada _pelo menos não da forma tradicionalmente concebida_ a responsabilidade social, ou melhor, a preocupação com o aspecto macro da sociedade. Usualmente, o sistema das regras sociais referentes à propriedade privada limita-se a fazer valer os direitos de exclusão que lhe são inerentes. Assim, preocupações acerca da distribuição equitativa de riqueza e do equilíbrio entre ricos e pobres são, geralmente, encaradas como questões externas à noção de propriedade privada, a serem enfrentadas, portanto, mediante escolhas políticas e ações positivas pelo Estado ${ }^{18}$ (WALDRON, 2012).

Por essas razões, sobretudo, que se acredita na necessidade de se pensar um sistema eclético de propriedade, de modo que permita a introdução de uma abordagem socialmente estratégica na construção da própria concepção.

Por sua vez, na tentativa de estruturar um conceito plural de propriedade, considerando os princípios e valores a que deve servir a noção, levanta-se o questionamento se se trata de forma ou de substância. Conforme já mencionado, Hohfeld (1917) é intimamente associado à concepção de propriedade a partir da metáfora do "feixe de gravetos", ou seja, um agregado complexo de direitos, enfatizando, assim, a substância em detrimento da forma da concepção. A referida metáfora é, portanto, invocada num esforço de examinar criticamente o conteúdo existente dos direitos que integram a propriedade e, assim, "libertar" o direito de propriedade dos limites de uma concepção puramente formal (DAGAN, 2011, p. 11). A referida noção, conforme destaca Dagan (2011), parte da ideia de que a propriedade consiste em uma construção do homem, podendo, portanto, submeter-se a modificações de acordo com os valores e as necessidades humanas.

Sob a ideia proposta pela referida metáfora, percebe-se, assim, que a posição do proprietário privado é mais bem entendida não como um único direito de uso e controle exclusivos sobre um determinado recurso, mas como um complexo feixe de direitos e deveres, que pode variar de acordo com o caso concreto e com o contexto em que está inserido (DAGAN, 2011).

\footnotetext{
${ }^{18}$ Como exemplos de políticas públicas nesse sentido, Waldron destaca as políticas de bem-estar e de tributação e a redistribuição em larga escala $(2012$, p. 2).
} 
Para Merrill (2011), a metáfora do "feixe" desempenhou, e tem desempenhado, um papel importante na elaboração da forma de pensar acerca de uma série de questões críticas a respeito da propriedade. A referida metáfora, destaca o autor, tem sido utilizada em face de controvérsias ligadas à finalidade da proteção constitucional da propriedade, tem estabelecido os termos dos debates em relação ao significado do conceito de propriedade, bem como tem ressaltado a complexidade da propriedade enquanto instituição para a organização dos recursos. Todavia, para Merrill (2011), a figura do "feixe de direitos" é mais bem sucedida para estabelecer questões do que, propriamente, para respondê-las. Assim, segundo o autor, a metáfora, que sugere que a propriedade é complexa e submete-se a mudanças, enfatizando a maleabilidade da propriedade, seria, ela própria, maleável demais para oferecer uma orientação clara na resolução de questões importantes (MERRILL, 2011, p. 247).

Merrill (2011) assinala que a propriedade não é apenas um direito constitucional ou um conceito, mas se trata de uma instituição social. Mais precisamente, coloca o autor, uma instituição para organizar a gestão dos recursos, que existe em maior ou menor grau em todas as sociedades humanas conhecidas. Diante dessa constatação, questiona se a metáfora do "feixe de gravetos" contribui para que se entendam as funções da propriedade enquanto instituição social. E o próprio autor responde que sim, porém em uma dimensão muito limitada. Segundo ele, a ideia do feixe nos ajuda a perceber a propriedade como uma instituição heterogênea, porém não fornece nenhuma assistência para discernir padrões ou explicações para as diferentes dimensões da propriedade que geram essa heterogeneidade. Para Merrill (2011), portanto, o feixe, que não possui uma forma definida, destaca a complexidade da instituição, mas não oferece quaisquer pontos de vista sobre sua natureza ou conteúdo (2011, p. 249).

Diante dessas considerações, segundo Merrill (2011), a propriedade seria melhor representada pela figura de um prisma. "Um prisma assume uma cor diferente a partir de ângulos diferentes, e assim o faz a propriedade"19 (MERRILL, 2011, p. 247). O autor sugere, então, quatro ângulos dos quais a propriedade pode ser vista, cada um correspondendo a um conjunto de regras. Conforme o ângulo que se enxerga a propriedade, portanto, haverá um complexo diverso de regras decifráveis por especialistas jurídicos - e não por leigos, como enfatiza. O prisma, coloca Merrill (2011), ao contrário do feixe, não sugere que os elementos constitutivos da propriedade são infinitamente variáveis sem considerar sob qual ponto de

19 Tradução livre de: "A prism takes on a different color from different angles, and so does property" (MERRILL, 2011, p. 247). 
vista estão sendo enxergados. Acrescenta que o "prisma da propriedade" permite um aprofundamento na busca pela compreensão da instituição da propriedade, sugerindo que a análise deva começar a partir de perguntas como "quem está olhando para a propriedade" e "por que".

Em sua concepção, Merrill (2011) entende que deve ser enfatizada a importância da identificação do que denomina de "público da propriedade" (audience of property). Segundo ele, diferentes públicos possuem diferentes necessidades na interação com a propriedade, e a natureza dessa interação exige informações diversas, podendo assumir diferentes graus de complexidade. Merrill (2011) sugere, então, que o prisma da propriedade pode ser visto por quatro ângulos, identificando-os como: "estranhos" (strangers), "potenciais negociadores" (potential transactors), "pessoas dentro da zona de particularidade" ("persons inside the zone of privity") e "vizinhos" (neighbors). Assim, o autor associa cores a cada um dos tipos de público que se submeterá a regras específicas a respeito da propriedade.

Para o público de "estranhos", o prisma da propriedade emitiria uma luz vermelha correspondente à ideia de exclusão. Para o público de "potenciais negociadores", uma luz âmbar, representando a propriedade a partir de uma quantidade finita de formas padrão, como o arrendamento, o condomínio, a servidão, e assim por diante. Aqui, coloca o autor, que as formas são suficientemente numerosas para atingir diferentes objetivos, porém devem observar o princípio do numerus clausus, previstas, portanto, em um número fechado de possibilidades, em virtude do que o autor coloca como custos de informação (information costs) (MERRILL, 2011).

O terceiro tipo de público é denominado pelo autor de "persons in the zone of privity", que ele explica como sendo as pessoas que compartilham determinado interesse em alguma parte da propriedade, definido por contrato, expressa ou implicitamente (entre os exemplos fornecidos pelo autor estão o locador e o locatário, o depositante e o depositário). Nesses casos, o autor coloca que o prisma da propriedade revela uma "luz verde constante". Nessa zona, segundo Merrill (2011), uma maior diversidade de regras e práticas é possível, e a explicação para deixar uma enorme quantidade de contratos aflorarem relaciona-se, mais uma vez, aos custos de informação. Regras e práticas idiossincráticas podem ser de grande utilidade em situações específicas envolvendo o gerenciamento contínuo de ativos específicos, com a livre implementação desses regramentos. Ao mesmo tempo, acrescenta o autor, os custos relacionados ao aprendizado dessas regras e práticas idiossincráticas são mais baixos 
para as pessoas dentro dessa zona, que normalmente interagem em uma base regular e, portanto, podem tomar conhecimento dessas regras e práticas sem dificuldades.

Por último, Merrill (2011) trata do público denominado de "vizinhos" (neighbors), que, segundo ele, abrange qualquer pessoa que experimente efeitos externos significativos a partir da forma como a propriedade é administrada. Esse público possui um tipo de relação distinta com a propriedade. Não são estranhos, uma vez que, geralmente, possuem algum conhecimento a respeito da identidade do proprietário e da natureza da atividade que envolve a propriedade. E também não são "potenciais negociadores" por, em geral, não haver acordos contratuais previamente estabelecidos entre eles e o proprietário. Nesse quarto ângulo, o prisma refletiria uma luz branca, composta de múltiplas cores do espectro. Nesse ponto, coloca o autor que o contexto influencia diretamente (a localização e a natureza da propriedade, sua utilização, expectativas culturais, etc.). Por sua vez, a natureza multifacetada da proteção legal para os "vizinhos" apresenta custos de informação relativamente altos, os quais são, segundo o autor, toleráveis, pelo fato de que a intervenção legal na proteção dos "vizinhos" tende a ser episódica. Desse modo, por se tratarem de mudanças episódicas, as partes afetadas devem se informar sobre as opções relevantes apenas quando surge um conflito suficientemente grave para justificar a ocorrência dos custos (MERRILL, 2011, p. 252).

De todo modo, é possível observar que tanto a metáfora do "feixe" quanto a do "prisma" reconhecem a heterogeneidade do direito de propriedade e a impossibilidade de reduzi-la à simples máxima de soberania do proprietário.

Como se pode perceber, a definição do conceito de propriedade é objeto de inúmeros e contínuos questionamentos. Waldron (2012) chega a assinalar que uma solução definitiva a respeito das controvérsias presentes na concepção de propriedade é provavelmente impossível. Tratar-se-ia, portanto, de um exemplo do que alguns filósofos denominam de "conceitos essencialmente contestados" (essentially contested concepts) (GALLIE, 1956).

Entretanto, ainda que se reconheça a dificuldade na definição do conceito, a noção relacionada a quais valores a propriedade _ou cada forma da propriedade _ deve servir é de extrema importância e assume um papel fundamental na solução de conflitos que envolvem o instituto. Deve-se estudar a fundo a extensão do conceito, para que ele seja operado da melhor forma possível para a sociedade como um todo.

Nesse sentido, entende-se que analisar a finalidade de cada tipo de propriedade existente na vida real permite, inclusive, que se reconheçam os propósitos normativos da 
legislação relacionada à proteção desse instituto nos mais diferentes contextos, o que, por sua vez, mostra-se imprescindível para a melhor aplicação das regras existentes, a fim de se possa alcançar a justiça social a partir da promoção dos valores que lhe são relacionados.

É necessário, pois, para uma adequada construção do conceito, que se tenha em mente a heterogeneidade das manifestações da propriedade na vida real. Essa heterogeneidade implica, por sua vez, que a maioria de nossas análises deve focar categorias mais estreitas do que a propriedade genericamente considerada, categorias que Dagan (2011) denomina de instituições da propriedade, cuja conformação pode corresponder mais adequadamente às características mais relevantes tanto dos recursos quanto das relações humanas envolvidas. Essa inclinação do autor em optar por categorias mais estreitas reflete, por sua vez, a influência realista sobre a sua concepção de propriedade e, por conseguinte, seu entendimento de que o direito deve servir à vida, o que será tratado de forma mais detalhada adiante.

Reconhece-se, portanto, que a propriedade é um conceito jurídico de extrema importância para um ordenamento comprometido com a garantia de relevantes valores individuais. Entretanto, ao mesmo tempo, é_e deve ser_também um instrumento na busca de outros objetivos igualmente valiosos, como a responsabilidade social e a justiça distributiva. Assim, apenas uma abordagem a partir de categorias mais estreitas é capaz de refletir, de modo mais adequado, os valores a que a propriedade deve servir.

\subsection{Propriedade enquanto conjunto de instituições: a inspiração na construção do conceito}

Em uma abordagem da história "da propriedade e das propriedades”, Grossi (2006), como já mencionado, faz um convite à relativização do instituto, ressaltando que, para o historiador, a propriedade deve ser um artifício verbal voltado a sinalizar a solução histórica que determinado ordenamento fornece ao problema da relação jurídica mais intensa entre um sujeito e um bem. Essas soluções, segundo ele, "são duplamente multíplices, conforme os vários climas históricos e segundo os vários conteúdos que um mesmo clima histórico dá àquele invólucro aberto e disponível que convencionalmente identificamos como propriedade" (GROSSI, 2006, p. 5). Assim, para o autor, a propriedade é, antes de tudo, uma mentalidade a expressar um complexo de valores circulares em uma área espacial e temporal, sendo a história do pertencimento e das relações jurídicas sobre as coisas, marcada, profundamente, pela descontinuidade. 
Nesse sentido, Grossi (2006) propõe uma interessante reflexão, assinalando "que no universo jurídico as formas são frequentemente somente as pontas emergentes de um gigantesco edifício submerso, um edifício construído sobre valores” (GROSSI, 2006, p. 32). Destaca que "a esses valores pede antes de mais nada o seu ser direito, regra observada e respeitada porque aderente às fontes mais vivas, de um costume, de crenças religiosas, de certezas sociais" (GROSSI, 2006, p. 33). Para o autor, somente isso poderia explica o retardo da construção jurídica de uma nova propriedade diante de um contexto social totalmente diverso.

Por sua vez, levando em consideração justamente a ideia de que a noção de propriedade reflete, de modos diversos, equilíbrios de valores relevantes na sociedade, Dagan (2011) constrói uma concepção contemporânea do instituto, tratando a propriedade como um conjunto de instituições.

Em oposição tanto à noção de Blackstone (2011), de propriedade como um domínio único e despótico, quanto à concepção perfilhada por Hohfeld (1917), representada pela metáfora do já mencionado desforme "feixe de gravetos", Dagan (2011) desenvolve uma interessante visão acerca da noção de propriedade, entendendo o conceito a partir da representação de um "guarda-chuva de um conjunto de instituições - instituições da propriedade - que carregam semelhanças entre si"20 (DAGAN, 2011, p. 42).

Na construção de seu conceito de propriedade, Dagan (2011) reconhece uma profunda influência do legado realista, haja vista sua proposta de que as categorias do direito estejam em sintonia com as categorias da vida e de que se proceda a uma análise contextual das diferentes instituições agrupadas sob o "guarda-chuva" da propriedade. Para o autor, a propriedade somente estará apta a promover o valor da liberdade no pluralismo e da individualidade na multiplicidade _ fundamentais para o ideal de justiça _, se facilitar as diversas formas de interação humana a partir da ideia de diferentes instituições, num contexto em que se reconheça o direito como um fenômeno social, em constante movimento (DAGAN, 2011, p. XIV).

Assim, considerando que as bases da concepção de propriedade ora defendida estão estruturadas sobre noções propostas pelo realismo jurídico, revelam-se oportunos alguns apontamentos acerca da visão de direito defendida por essa linha de pensamento.

\footnotetext{
${ }^{20}$ Tradução livre de: "Property is an umbrella for a set of institutions - property institutions - bearing family resemblances" (DAGAN, 2011, p. 42).
} 
2.3.1 O realismo jurídico: breves noções gerais sobre as premissas que inspiraram a construção de um conceito contemporâneo de propriedade

Afirma-se que o realismo jurídico norte-americano foi um movimento dotado de dupla faceta: uma teoria do ensino e uma teoria do direito. O movimento consolida-se nos Estados Unidos entre as décadas de 1920 e 1930 como uma crítica, principalmente, ao método do caso desenvolvido por Christopher Columbus Langdell (FERREIRA, 2012).

Langdell (1871 apud GILMORE, 2014) defendia que todo o material disponível e necessário para a ciência do direito estaria contido nos livros impressos. E, assim, afirmava: "a biblioteca é para nós o que os laboratórios das universidades são para os químicos e físicos, o que o museu de história natural é para o zoólogo e o que o jardim botânico é para os botânicos" ${ }^{21}$ (LANGDELL, 1871 apud GILMORE, 2014, p. 42). Os autores considerados realistas, por sua vez, criticavam a cientificidade do direito exposto pelo referido entendimento tanto como método de ensino quanto como teoria do direito.

Holmes (1992) é reconhecido como o precursor do realismo, por hostilizar, desde os últimos anos do século XVIII, o formalismo jurídico de Langdell (1871 apud GILMORE, 2014) e introduzir uma interpretação do direito mais sensível às mudanças sociais. Em suas obras, o autor pondera que o direito não é lógica, mas experiência, resultado de um sistema de interações e de uma prática política generalizada que envolve inúmeras outras considerações. Para o autor, a relação do jurista ao entender o direito e conferir-lhe determinado tratamento não tem a mesma natureza que o tratamento que o físico confere às leis da física, uma vez que a vida do direito consiste na tomada de decisões (por pessoas) dentro de instituições (submetidas a influência política). Vai muito além, portanto, de uma mera descrição. Assim, para Holmes (1992), considerando esse sistema de interações, cabe ao direito prever como os juízes irão julgar determinada matéria (HOLMES, 1992, p. 160).

Quando estudamos direito não estamos tratando de um mistério, porém de uma
profissão muito conhecida. Estudamos o que devemos buscar ao falarmos com um
juiz, ou como aconselhar as pessoas de modo que elas evitem problemas e fiquem
distantes dos tribunais. A razão pela qual o direito é uma profissão, os motivos pelos
quais as pessoas pagam advogados que as representem junto aos juízes, reside no
fato de que em sociedades como a nossa o comando da força pública está
concentrado em juízes, que movimentam toda força do Estado, se necessário, para
o implemento das decisões judiciais. As pessoas querem saber sob quais

21 "Langdell's idea was that law is a science. He once explained how literally he took that doubtful proposition: [A]ll the available materials of that science [that is, law] are contained in printed books. ... [T] he library is... to us all that the laboratories of the university are to the chemists and physicists, all that the museum of natural history is to zoologists, all that the botanical garden is to the botanists..." (GILMORE, 2014, p. 42). 
circunstâncias e até onde elas correm riscos de se encontrarem em face do que é muito mais forte do que elas, e consequentemente isso se torna um negócio a resolver, quando tal perigo é fonte de temor. O objeto de nosso estudo, então, é previsão, é a previsão da incidência da força pública como instrumento das cortes de justiça $^{22}$ (HOLMES, 1992, p.160).

Holmes (1992) utiliza a figura do que ele denomina de "homem mau" (bad man) para evidenciar quem seria a pessoa interessada em saber o que sofreria, caso violasse a lei. Assim, o autor apresenta sua teoria, baseada na previsão, a fim de demonstrar a possibilidade de se antever as decisões proferidas pelos tribunais (HOLMES, 1992). A decisão judicial seria, então, passível de ser antecipada, a partir do conhecimento sobre como os juízes decidiram, anteriormente, em outros casos semelhantes, mas também considerando todos os demais elementos relacionados a esse sistema de interações, como, por exemplo, a doutrina e a legislação.

Por sua vez, a denominação do movimento, como realismo, ocorre em 1930 com o artigo de Llewellyn (1930) intitulado A Realistic Jurisprudence: the next step. Vale ressaltar que, embora o autor tenha utilizado, pela primeira vez, o termo "realismo" para classificar essa nova forma de pensar, trata-se apenas de uma verificação formal da já existente crítica ao formalismo jurídico de Langdell (apud GILMORE, 2014), que vinha ocorrendo em outros autores, como, por exemplo, o já mencionado Holmes (1992).

Em seu artigo, Llewellyn (1930) traz uma diferenciação entre as regras reais (real rules) e as regras de papel (paper rules). As primeiras seriam aquelas efetivamente utilizadas pelos tribunais na tomada de suas decisões, enquanto as segundas consistiriam nas regras descritas nos livros, destituídas, contudo, de aplicabilidade real (LLEWELLYN, 1930, p. 448). O autor assinala que "a linha de pensamento mais frutífera sobre o direito deve enxergálo como um motor (uma multiplicidade heterogênea de motores) com propósitos, e não valores em si mesmo"23 (LLEWELLYN, 1930, p. 464). Acrescenta que se deve dar menos importância às palavras, à letra fria da lei, e mais ênfase ao que chama de "comportamento

\footnotetext{
${ }^{22}$ Tradução livre de: "When we study law we are not studying a mystery but a well-known profession. We are studying what we shall want in order to appear before judges, or to advise people in such a way as to keep them out of court. The reason why it is a profession, why people will pay lawyers to argue for them or to advise them, is that in societies like ours the command of the public force is intrusted to the judges in certain cases, and the whole power of the state will be put forth, if necessary, to carry out their judgments and decrees. People want to know under what circumstances and how far they will run the risk of coming against what is so much stronger than themselves, and hence it becomes a business to find out when this danger is to be feared. The object of our study, then, is prediction, the prediction of the incidence of the public force through the instrumentality of the courts" (HOLMES, 1992, p.160).

${ }^{23}$ Tradução livre de: "I have argued that the trend of the most fruitful thinking about law has run steadily toward regarding law as a engine (a heterogeneous multitude of engines) having purposes, not values it self [...]" (LLEWELLYN, 1930, p. 464).
} 
observável" (observable behavior), no qual quaisquer atitudes prováveis e padrões de pensamento devem ser incluídos (LLEWELLYN, 1930, p. 464).

\begin{abstract}
De fato, que é o foco do estudo, o ponto de referência para todas as coisas jurídicas está se deslocando e deve agora ser conscientemente alterado para a área de contato, de interação, entre o comportamento de regulamentação oficial e o comportamento daqueles que estão sendo ou foram afetados pelo comportamento de regulamentação oficial; e que as regras e preceitos e princípios que até agora tendiam a manter o centro da atenção devem ser deslocados e tratados de acordo com sua influência sobre a área de contato - a fim de que as regras de papel possam ser reveladas por aquilo que são, e às regras com correspondentes de comportamentos reais seja dada a devida importância. Que esse complexo fenômeno agrupado sob o termo "direito" que tem sido tratado amplamente no passado, e que o entendimento realista, possível apenas em termos de comportamento observável, é de novo possível apenas em termos de estudo da maneira como as pessoas e as instituições são organizadas em nossa sociedade, e dos fardos de qualquer parte particular do direito ou de qualquer parte particular do social da organização social ${ }^{24}$ (LLEWELLYN, 1930, p. 464).
\end{abstract}

Não obstante haja outros grandes defensores do pensamento realista, as ideias de Holmes (1992) e Llewellyn (1930) refletem bem essa visão, que defende, dentre outros pontos, que o direito, embora dotado de certa estabilidade, é algo em fluxo, em constante mutação, devendo, de tempos em tempos, adaptar-se à dinamicidade da sociedade. $\mathrm{O}$ direito, para o realismo jurídico, deve, pois, ser abordado em consideração aos seus propósitos, por tratar-se de um meio para atingir determinados fins. Diferentemente da moral, portanto, não há um valor em si em obedecer-lhe, devendo ser incluídas, na própria concepção do direito, as consequências, na vida real, das regras descritas no ordenamento. Ademais, vale dizer que o fato de considerar o direito como experiência _ e não lógica_ não significa negar o uso da razão dentro do direito, mas, sim, enxergá-la como parte dessa experiência.

Conforme Dagan (2011) assinala, essa linha de pensamento influenciou a construção de sua noção da propriedade, tratando-se das bases sobre as quais o conceito é estabalecido.

\footnotetext{
${ }^{24}$ Tradução livre de: "Indeed that the focus of study, the point of reference for all things legal have been shifting, and should now be consciously shifted to the area of contact, of interaction, between official regulatory behavior and the behavior of those affecting or affected by official regulatory behavior; and that the rules and precepts and principles which have hitherto tended to keep the limelight should be displaced, and treated with severe reference to their bearing upon that area of contact - in order that paper rules may be revealed for what they are, and rules with real behavior correspondences come into due importance. That the complex phenomenon which are lumped under the term "law" have been too broadly treated in the past, and that a realist understanding, possible only in terms of observable behavior is again possible only in terms of study of the way in which person and institutions are organized in our society, and the cross-bearings of any particular part of law and of any particular part of the social of the social organization" (LLEWELLYN, 1930, p. 464).
} 
2.3.2 A influência do realismo jurídico na concepção de propriedade

Como mencionado, Dagan (2011) qualifica sua abordagem como realista, apresentando, ele próprio, as razões que o levam a atribuir à sua concepção de propriedade as características peculiares dessa linha de pensamento. Em primeiro lugar, ressalta, como já observado em Holmes (1992) e em Llewellyn (1930), que o ponto de partida dessa visão é o seu não positivismo. Nesse sentido, destaca o autor que o argumento realista relaciona-se à lacuna existente entre estudos doutrinários e os resultados judiciais, o que, segundo ele, enseja duas preocupações principais: inteligibilidade e legitimidade.

Em outras palavras, essa afirmação abre espaço para dois questionamentos. Primeiro, o que pode explicar o comportamento judicial passado e prever seu futuro curso? Segundo, e ainda mais importante, como pode o direito restringir julgamentos feitos por juízes não eleitos? Como, então, pode a distinção entre direito e política ser mantida apesar do colapso da autonomia do direito em sua interpretação positivista? A questão da legitimidade no desafio realista é particularmente formidável porque, como mostram os realistas jurídicos, é apoiada pela tendência insidiosa do doutrinalismo jurídico de obscurecer juízos de valor contestáveis realizados por juízes e de entrincheirar alegações de advogados em um profissionalismo impenetrável (DAGAN, 2011, p. XIX) ${ }^{25}$.

Os realistas jurídicos respondem a esses desafios, segundo ele, insistindo na visão do direito como uma instituição em movimento que se difere pela difícil acomodação de três tensões jamais resolvidas: poder e razão, ciência e ofício, tradição e progresso. Por seu turno, os realistas rejeitam qualquer concepção de direito que pretenda dissolver essas tensões, obscurecendo, assim, ao menos uma das características irredutíveis do fenômeno jurídico.

Embora a concepção realista encontre espaço para a razão e o poder, ela reconhece a dificuldade de sua convivência e enxerga na coercibilidade o centro da definição do direito. Essa preocupação com a coerção justifica-se não apenas pelo fato de que, diferentemente de outros tipos de julgamentos, aqueles prescritos pelos operadores jurídicos podem reforçar o monopólio do poder do Estado. Mais que isso, a referida preocupação justifica-se, sobretudo, frente aos meios discursivos e institucionais que tendem a minimizar as dimensões do poder do direito. Assim, algumas características que integram o direito _ como a divisão de trabalho

\footnotetext{
${ }^{25}$ Tradução livre de: "In others words, this claim opens up two questions. First, what can explain past judicial behavior and predict its future course? Second, and even more significantly, how can law constrain judgments made by unelected judges? How, then, can the distinction between law and politics be maintained despite the collapse of law's autonomy in its positivist rendition? The legitimacy prong of the realist challenge is particularly formidable because, as legal realists show, it is bolstered by the insidious tendency of legal doctrinalism to obscure contestable value judgments made by judges and to entrench lawyers' claim to an impenetrable professionalism" (DAGAN, 2011, p. XIX).
} 
entre "especialistas em interpretação" e aqueles que proferem o julgamento; e a tendência dos operadores do direito, e até de cidadãos, de "coisificar" construções jurídicas e conferir-lhes um aspecto de obviedade e aceitabilidade _ ensejam o perigo de ocultar sua coercibilidade, o que pode ser visto como uma armadilha, a ensejar, no mínimo, certa desconfiança quanto a qualquer tentativa de dissimular ou esconder a existência dessa coercibilidade característica. Diante disso, não surpreendentemente, os realistas "focam sua atenção em expor a contingência de determinados conceitos principais do direito privado, em uma tentativa de expor as maneiras como o direito aplica seu poder"26 (DAGAN, 2011, p. XIX).

Os realistas rejeitam, ainda, considerando-a igualmente reduzida, a imagem do direito como um mero reflexo, que retrata puro poder, interesse ou política (DAGAN, 2011).

Na verdade, ressalta Dagan (2011), os realistas jurídicos reconhecem que o direito é o lugar da razão, esta que, por sua vez, tem o condão de limitar as escolhas dos responsáveis pelas tomadas de decisão judicial e, portanto, o exercício do poder estatal. "A lei nunca diz respeito tão somente a interesse e poder políticos, é também um exercício da razão"27 (2011, p. XIX).

Deve-se ter em mente que o raciocínio jurídico, o exercício da razão, é capaz de justificar a coerção do direito apenas se estiver, ao menos implicitamente, fundado em valores humanos. Assim, considerar que a tensão entre razão e poder é uma característica inerente ao direito significa que qualquer teoria reducionista que emprega uma concepção excessivamente romântica ou cínica do direito deve ser rejeitada (DAGAN, 2011).

Quanto ao tratamento realista da tensão entre o que Dagan (2011) coloca como ciência e ofício, esse deriva da mencionada convicção dos realistas jurídicos de que o direito é profundamente dinâmico. A esse respeito, reconhece-se uma diferença entre os juristas enquanto engenheiros sociais que, segundo ele, sem nenhuma paixão, combinam conhecimento empírico com ideias jurídicas e, de outro lado, os argumentadores práticos, que empregam julgamentos contextuais como parte de um processo de adjudicação dialógica (DAGAN, 2011, p. XX).

$\mathrm{Na}$ verdade, os realistas percebem que juízos de valor são indispensáveis não só ao avaliar a pesquisa empírica, mas quando se trata, inclusive, de escolher os fatos que serão

\footnotetext{
${ }^{26}$ Tradução livre de: "Not surprisingly, then, legal realists focus their attention on exposing the contingency of some core concepts of private law in an attempt to expose the ways in which the Law applies its power" (DAGAN, 2011, p. XIX).

${ }^{27}$ Tradução livre de: "Law is never only about interest or power politics, it is also an exercise in reason-giving" (DAGAN, 2011, p. XIX).
} 
investigados. Conforme mencionado, cuida-se, portanto, de escolhas. A análise jurídica necessita, assim, tanto de dados empíricos como de juízos normativos. Porque o direito afeta dramaticamente a vida das pessoas, esses fatos sociais e valores humanos devem sempre informar a evolução do direito. O raciocínio jurídico necessariamente compartilha essa característica com outras formas de raciocínio prático, todavia, a concepção realista do direito também enfatiza que o raciocínio jurídico é, em alguma extensão, uma forma distinta de argumentação e análise. Desse modo, os realistas procuram focar características institucionais distintas do direito e estudar suas potenciais virtudes, enquanto estão, ainda, conscientes de seu possível abuso. Nesse sentido, Dagan (2011) destaca que "as características processuais do processo adversário, assim como as normas profissionais que ligam opiniões judiciais, notadamente, a exigência de justificação universalizável, proporcionam um ambiente social único para o julgamento" ${ }^{28}$. Essas características processuais estabelecem a responsabilidade das carreiras jurídicas de desenvolver o que Cohen (1950) chama de uma visão do mundo sob uma perspectiva múltipla, a qual, segundo ele, é a única forma de "nos aliviar da anarquia infinita de uma visão monocular" ${ }^{29}$ (COHEN, 1950, p. 242) .

Por conseguinte, a contextualização de juízos normativos garante aos juristas uma habilidade única de capturar as sutilezas de vários tipos de casos e ajustar o tratamento jurídico às características distintas de cada categoria.

Assim, o tratamento realista à tensão entre ciência e ofício _entre a construção de uma teoria e a prática de um mister que afeta diretamente a vida das pessoas _ pode ser tido como uma decorrência da convicção de que o direito é profundamente dinâmico, o que, por sua vez, sinaliza e se estende à terceira tensão inerente ao direito: tradição e progresso. A referida convicção implica, em primeiro lugar, que a tentativa do positivismo jurídico de entender o direito estaticamente mediante pura referência a fatos verificáveis é inviável. Nesse ponto, interessantes as observações de Dewey (1941) no sentido de que o direito é uma instituição em movimento (a going institution), "um fenômeno completamente social; social em origem, em propósito ou fim, e em aplicação" ${ }^{30}$ (DEWEY, 1941, p. 117).

\footnotetext{
${ }^{28}$ Tradução livre de: "The procedural characteristics of the adversary process, as well as the professional norms that bind judicial opinions, notably the requirement of a universalizable justification provide a unique social setting for adjudication" (DAGAN, 2011, XXI).

${ }^{29}$ Tradução livre de: "The proposition that no man should be a judge of his own cause embodies the ancient wisdom that only a many-perspectived view of the world can relieve us of the endless anarchy of one-eyed vision (COHEN, 1950, p. 24).

${ }^{30}$ Tradução livre de: "The standpoint taken is that the law is through and through a social phenomenon; social in origin, in purpose or end, and in application" (DEWEY, 1941, p. 117).
} 
Defende-se que tudo o que se refere a social, significa que se aplica, em primeiro lugar, às atividades humanas, e, em segundo lugar, a estas atividades enquanto formas de comportamento, como interatividades. Ao afirmar que fatos sociais, ou fenômenos, são atividades, significa, negativamente, que não são fatos do tipo indicado quando "fato" é tomado como algo feito, terminado e passado; e, positivamente, que são processos, coisas em curso. [...] Com referência ao direito, esse posicionamento significa que o direito deve ser enxergado tanto como uma intervenção no complexo de outras atividades, quanto como o próprio processo social, algo que não pode ser dito para ser feito ou para acontecer em uma data determinada. A primeira parte da afirmação anterior significa que o "direito" não pode ser tratado como se fosse uma entidade separada, mas pode ser discutido somente em termos da condição social na qual ele surge e do que concretamente faz ali $^{31}$ (DEWEY, 1941, p. 117).

O autor conclui que aquilo que é denominado de aplicação não é algo que acontece depois que a regra ou a lei são previstas, mas se trata de uma parte necessária, integrante do direito. Segundo ele, uma parte tão necessária que, em determinados casos, é possível julgar o que o direito é como a matéria de fato, apenas dizendo como ele funciona e quais os efeitos surte sobre as atividades humanas. Assim, nas lições do autor, um determinado dispositivo jurídico consiste no que ele faz, "e o que ele faz remete ao campo de modificação e/ou manutenção de atividades humanas, como empresas em funcionamento"32 (DEWEY, 1941, pp. 117-118). Desse modo, Dewey (1941) entende que a aplicação das normas compõe a estrutura da própria concepção do direito, sem a qual o que passa a existir são meros "pedaços de papéis ou vozes no ar, mas nada que possa ser chamado de direito"33 (DEWEY, 1941, p.118).

Dewey (1941) enfatiza, portanto, a importância das consequências, em função do que se passa socialmente. Segundo o autor, para o constante aprimoramento do direito, é necessário investigar, em termos de contexto de situações reais, as consequências de regras legais, das decisões jurídicas propostas e dos atos legislativos (DEWEY, 1941, p. 121).

Nesse sentido, como uma instituição em movimento, o direito estrutura-se como um processo infinito de verificações e reverificações, a ser entendido como um "grande

\footnotetext{
${ }^{31}$ Tradução livre de: "It is postulated that whatever else social means it applies, first, to human activities, and secondly to these activities as forms of behavior, as interactivities. By saying that social facts, or phenomena, are activities, it is meant, negatively, that they are not facts of the kind indicated when 'fact' is taken to mean something done, finished, and over with; and positively that they are processes, things going on. [...] With reference to law, this position signifies that law must be viewed both as intervening in the complex of others activities, and as itself a social process, not something that can be said to be done or to happen at a certain date. The first part of the foregoing statement means that 'law' cannot be set up as if it were a separate entity, but can be discussed only in terms of the social condition in which it arises and of what it concretely does there" (DEWEY, 1941, p. 117).

${ }^{32}$ Tradução livre de: "A given legal arrangement is what it does, and what it does lies in the field of modifying and/or maintaining human activities as going concerns" (DEWEY, 1941, pp. 117-118).

${ }^{33}$ Tradução livre de: "Without application there are scraps of papers or voices in the air but nothing that can be called Law" (DEWEY, 1941, p. 118).
} 
laboratório humano em uma busca constante de aperfeiçoamento" ${ }^{34}$ (DAGAN, 2011, p. XXI). Ao mesmo tempo, contudo, essa constante busca por justiça e ajustamento encontra limites na tradição jurídica. O passado serve como ponto de partida para a análise contemporânea, devendo ser respeitado, ainda que se constate a necessidade de transformação em prol do progresso. Eis, portanto, a terceira tensão: há que se viabilizar o progresso sem, contudo, abandonar totalmente a tradição e as formas existentes.

Nessa visão dinâmica do direito a serviço da vida, admitindo-se as tensões indissolúveis que lhe são inerentes, a propriedade está conectada intimamente ao Estado e à comunidade, tratando-se de um conceito jurídico essencial para um regime comprometido em garantir, além de importantes valores individuais _ como autonomia, pessoalidade e merecimento _, objetivos valiosos como responsabilidade social e justiça distributiva.

Assim, para Dagan (2011), apenas uma concepção inspirada no realismo, que reconhece a multiplicidade dos valores da propriedade e celebra a pluralidade de suas instituições, é capaz de enfrentar o desafio de acomodar os aparentes conflitos entre as visões da propriedade. Segundo ele, somente com base nessa proposta é possível construir uma concepção que abarque as nuances que a propriedade pode assumir em diferentes situações, enxergando o direito de propriedade como parte integrante de uma perspectiva institucional mais ampla (DAGAN, 2011, XXV).

\subsubsection{Propriedade: tanto forma, quanto substância}

A partir dessa visão realista do direito, Dagan (2011), então, constrói uma concepção de propriedade relacionada à ideia de instituições, que representam importantes molduras das interações interpessoais, consolidando, assim, as expectativas das pessoas e expressando os ideais normativos do direito para o centro de relações humanas. Como já ressaltado, o autor defende que, somente facilitando as diversas formas de interação humana a partir da previsão de diferentes instituições da propriedade, a propriedade possibilitará a promoção do valor do pluralismo _ e da liberdade nele reforçado _ e o papel da individualidade na multiplicidade, ambos essenciais para um ideal de justiça (DAGAN, 2011, p. XIV).

As instituições da propriedade, portanto, mediam a relação entre proprietários e não proprietários quanto a um determinado recurso. Nesse ponto, Dagan (2011) reconhece que em

\footnotetext{
${ }^{34}$ Tradução livre de: “[...] law is a great human laboratory continuously seeking improvement” (DAGAN, 2011, p. XXI).
} 
todas essas relações os proprietários possuem algum direito ligado à exclusão de terceiros e à determinação da agenda do recurso de forma exclusiva. Esse denominador comum deriva do papel da propriedade de garantir a autonomia. Entretanto, enfatiza, ao lado desse importante valor da propriedade, outros valores desempenham papéis cruciais na formação do conceito e das instituições que o integram. Desse modo, a propriedade deve servir também a compromissos com o merecimento, a agregação de bem estar social e a justiça distributiva (DAGAN, 2011, p. XVIII).

Assim, como já mencionado, contrapondo-se tanto à concepção de Blackstone (2011), de propriedade como um domínio único e despótico, quanto à noção de Hohfeld (1917), do "feixe de gravetos”, Dagan (2011) constroi sua noção de propriedade, considerada, por ele, um "guarda-chuva de um conjunto de instituições - instituições da propriedade - que carregam semelhanças entre si" ${ }^{\prime 35}$ (DAGAN, 2011, p. 42).

Conforme já visto, Blackstone (2011), em uma visão associada profundamente à ideia de exclusividade da propriedade, definiu o instituto como "um domínio único e despótico, que permite ao proprietário exercer e reivindicar seu direito em face das outras coisas externas do mundo, em total exclusão do direito de qualquer outro indivíduo no universo" ${ }^{\text {36 }}$ (BLACKSTONE, 2011, p. 304). Enfatiza-se, nessa concepção, a forma do instituto.

Ao contrário, Hohfeld (1917) defendia que os direitos de propriedade não podiam ser visto como um único direito oponível a todos (HOHFELD, 1917, p. 743). Como visto, o autor defende a ideia da propriedade enquanto um "feixe de gravetos", envolvendo múltiplos direitos e múltiplas relações de direitos e deveres entre várias pessoas, independentes entre si. Evidencia-se, assim, diferentemente de Blackstone (2011), a substância, o conteúdo da propriedade.

Na linha de Hohfeld (1917), Waldron (1988) destaca a existência de várias relações independentes envolvendo a propriedade. Por serem distintas e separadas, "as relações componentes podem ser desmontadas e reconstituídas em combinações diferentes, para que

\footnotetext{
35 Tradução livre de: "Property is an umbrella for a set of institutions - property institutions - bearing family resemblances" (DAGAN, 2011, p. 42).

${ }^{36}$ Tradução livre de: "That sole and despotic dominion which one man claims and exercises over the external things of the world, in total exclusion of the right of any other individual in the universe" (BLACKSTONE, 2011, p. 304).
} 
possamos obter feixes menores dos direitos envolvidos originariamente no conjunto maior que chamamos de propriedade" ${ }^{37}$ (WALDRON, 1988, p. 28).

A esse respeito, Waldron (1988) assinala que pessoas como o locador ou cujo imóvel esteja hipotecado continuam sendo consideradas proprietárias. Todavia, a propriedade daquele que concedeu a hipoteca de seu imóvel difere da propriedade do que o alugou para terceiro, as quais, por sua vez, não se confundem com a propriedade daquele que não transmitiu qualquer dos direitos pertencentes ao "feixe original". Assim, nas palavras do autor, "dependendo das transações particulares em questão, cada tipo de propriedade será composta por um diferente conjunto de direitos" ${ }^{38}$ (1988, p. 28).

Também Dagan (2011) reconhece a existência de feixes de direitos e de possíveis combinações, que se relacionam de maneira diversa e com relativa independência entre si. Se a propriedade é um feixe, pondera, significa que não existe uma composição canônica do conceito e que a referência à concepção de propriedade é, na verdade, um convite a uma investigação normativa, mais do que, propriamente, um "pacote de incidentes inevitáveis" (DAGAN, 2011, p. 11). Ademais, reconhecer a propriedade enquanto feixe de direitos afasta a possibilidade de uma "metodologia imaginária" de raciocínios dedutivos a partir de formas congeladas, o que é contundentemente criticado pelo autor (DAGAN, 2011, p. 12).

Todavia, para Dagan (2011) não se trata apenas de substância. As formas da propriedade não podem ser irrefletidamente descartadas, uma vez que representam as molduras padrão das interações entre pessoas. Nesse sentido, a propriedade deve ser encarada como um conjunto de relações interpessoais, enquadráveis, por sua vez, em formas estabelecidas.

A metáfora do feixe, portanto, não pode ser erroneamente interpretada ensejando o entendimento de que a propriedade pode ser concebida como um rol infinito de direitos substantivos com permutações ilimitadas. Ao mesmo tempo, as formas da propriedade não devem ser tratadas como entidades abstratas dotadas de um conteúdo e uma estrutura interna intocáveis. Um raciocício como esse, que entende a propriedade unicamente como forma, é censurável, inclusive, porque, falsamente, apresenta juízos de valor realizados por julgadores como inevitáveis, obscurecendo suas escolhas e os protegendo de críticas empíricas e

\footnotetext{
${ }^{37}$ Tradução livre de: "Because they are distinct and separable, the component relations may be taken apart and reconstituted in differents combinations, so that we may get smaller bundles of the rights that were involved originally in this large bundle we called ownership" (WALDRON, 1988, p. 28).

${ }^{38}$ Tradução livre de: "[...] depending on the particular transactions that have taken place, each has a different bundle of rights" (WALDRON, 1988, p. 28).
} 
normativas. Assim, para saber como e se a configuração existente da forma da propriedade afeta um resultado jurídico ou determinada decisão, deve-se analisar as formas da propriedade de uma perspectiva normativa e contextual. "As formas da propriedade devem afetar os resultados na medida em que possam ajudar a constituir instituições da propriedade que sirvam a importantes valores" 39 (DAGAN, 2011, p. 12).

Nessa linha de raciocínio, Dagan (2011), reconhecendo pontos positivos em cada uma das concepções, enxerga, como já mencionado, a propriedade como um conjunto de instituições, categorias mais estreitas do que a propriedade em si, cujo formato pode responder de modo mais adequado às características relevantes tanto dos recursos quanto das relações humanas envolvidas.

Normativamente, portanto, a propriedade serve a um complexo de valores pluralistas, entre os quais se incluem tanto a utilidade e a autonomia _ estes que são enfatizados pelas escolas contemporâneas _, como o trabalho, a pessoalidade, a comunidade, a liberdade e a justiça distributiva (DAGAN, 2011, p. XII). Enquanto forma, corresponde a uma moldura da interação interpessoal que consolida as expectativas das pessoas e expressa os ideais normativos do direito para o centro das relações humanas.

Nesse ponto, quanto aos valores a que a propriedade deve servir, observa-se, ainda, a interessante abordagem de Cohen (2000), que defende que a falta de meios põe em perigo a liberdade, que não é ilimitada, mas restrita pela distribuição da riqueza. O autor coloca que, naturalmente, a falta de riqueza, ou seja, a pobreza, não é a única circunstância que limita a liberdade de uma pessoa, mas é, segundo ele, uma das mais importantes. O dinheiro, assim, segundo ele, outorga a liberdade e a falta dele afeta diretamente esse direito fundamental (COHEN, 2000, p. 52).

Do ponto de vista estrutural, coloca Cohen (2000), as sociedades possuem maneiras distintas de induzir a distribuição da liberdade, e em uma sociedade como a nossa, em que a liberdade é afetada diretamente pela distribuição da riqueza, muitas vezes o fato de que o dinheiro estrutura a liberdade não é apreciado devidamente, produzindo-se a ilusão de que a liberdade é ilimitada, ao invés de estar restrita pela forma como a riqueza é distribuída na sociedade (2000, p. 60).

Assim, destaca Cohen (2000) que o protesto contra a pobreza reflete a defesa da liberdade e, mais particularmente, consiste em uma manifestação contra a extrema falta de

${ }^{39}$ Tradução livre de: "The forms of property should affect outcomes to the extent that they help constitute property institutions that serve important human values" (DAGAN, 2011, p. 12). 
liberdade das pessoas pobres na sociedade capitalista e em favor de uma distribuição muito mais equitativa desse direito (2000, p. 69).

A partir da concepção de Cohen (2000), é possível afirmar, pois, que a distribuição equitativa da riqueza e, por conseguinte, da propriedade, implica, assim, em uma distribuição equitativa da liberdade.

Todavia, conforme já destacado, não obstante a propriedade se relacionar diretamente à liberdade e à justiça, em geral, não integra a lógica da propriedade privada a preocupação com o aspecto macro da sociedade. Geralmente, não se insere na construção do conceito a preocupação com a configuração social resultante da distribuição de riqueza advinda da transferência da propriedade privada, o que, todavia, merece ser revisto.

É possível perceber, portanto, que a pluralidade da propriedade e dos valores a que o instituto deve servir reflete, na verdade, a heterogeneidade de suas manifestações na vida real, o que, tal como Dagan (2011), entendemos que não pode ser desconsiderado ao se estudar a construção do conceito. Como será visto, é justamente essa heterogeneidade que justifica a utilização de categorias mais estreitas como objetos de análise _ categorias, pois, mais próximas ao específico equilíbrio de valores humanos a ser efetivamente tutelado_, denominadas por Dagan (2011) de "instituições da propriedade".

\subsubsection{A propriedade como um conjunto de instituições}

Conforme já mencionado, Dagan (2011) define a propriedade como um "guarda-chuva de um conjunto de instituições - instituições da propriedade - que carregam semelhanças entre si"40 (2011, p. 42). Essa inclinação realista por optar por categorias relativamente estreitas segue diretamente seu compromisso de garantir que o direito sirva à vida. Isso porque, nas palavras de Dagan (2011), categorias estreitas permitem que os operadores do direito desenvolvam a distinção necessária para um tratamento de intimidade, permitindo-lhes que se mantenham próximos à verdadeira "transação da vida" (transaction of life) diante deles, encorajando-os a conformar a lei de forma próxima e contemporânea aos problemas humanos com o que estão lidando (DAGAN, 2011, p. XXIII).

\footnotetext{
${ }^{40}$ Tradução livre de: "Property is an umbrella for a set of institutions - property institutions - bearing family resemblances" (DAGAN, 2011, p. 42).
} 
Entretanto, a teoria da propriedade deve afastar-se de uma abordagem nominalista, de julgamento caso a caso, buscando uma visão de sentido e razão de algum tipo significativo de situação da vida já vista. Assim, identificar autonomia, pessoalidade, utilidade, trabalho, comunidade e justiça distributiva como valores inerentes à propriedade não deve criar a ideia de levar os juízes a, rotineiramente, fazer julgamentos ad hoc, baseados nesses valores. A teoria da propriedade não deve implicar, pois, a problemática abordagem da regra sensitiva do particularismo, permitindo que juízes afastem-se das regras sempre que o resultado de um caso particular assim exigir. Deve-se ter em conta não apenas os valores substanciais relacionados à propriedade, mas também a própria preservação da integridade da regra, reconhecida por Dagan (2011) também como um valor (DAGAN, 2011, p. XXIV). Na verdade, ressalta Dagan (2011) que o reconhecimento desses valores como integrantes da estrutura do direito de propriedade deve aconselhar os atores jurídicos a, ocasionalmente, utilizar novos casos como pontos de partida para o aperfeiçoamento constante das regras, sem, contudo, desconsiderá-las e admitindo a importância de sua preservação.

Assim, a heterogeneidade prescrita pelo pluralismo de valores implica a ideia de que diferentes valores ou diferentes equilíbrios devem orientar diferentes áreas do direito e da vida, mas não deve, de forma alguma, ser equiparada a um convite a aplicar preferências subjetivas. Tipos diferentes de interação humana e, consequentemente, categorias distintas de propriedade exigem, sim, equilíbrios diferentes a respeito dos compromissos normativos gerais, não se tratando, contudo, de criação de novas regras de forma totalmente particular, para cada situação (DAGAN, 2011).

Dagan (2011) observa que a abordagem realista da propriedade não descarta ou qualifica como essenciais as formas da propriedade. Todavia, em sua concepção, as instituições da propriedade devem ser o ponto de partida da análise de questões sobre a propriedade. Desse modo, na abordagem da propriedade como um conjunto de instituições, supõe-se que as configurações existentes de direitos, privilégios, poderes e imunidades de determinada instituição da propriedade constituem um quadro útil da interação social. Dagan (2011) coloca que esse pressuposto, considerado por ele próprio conservador, deriva tanto da realidade pragmática de que as normas vigentes não podem ser totalmente abandonadas, como do reconhecimento de que as formas existentes de propriedade representam um acúmulo de experiência que merece respeito.

Entende o autor que esse repertório já existente de formas da propriedade, na verdade, oferece uma "sugestão provisória de como analisar o mundo social em categorias distintas de 
interações humanas" ${ }^{41}$ (DAGAN, 2011, p. 28). Isso porque as pessoas interagem de inúmeras maneiras, a depender de como se relacionam com os outros. O espectro de relações, portanto, varia de relações de plena concorrência entre estranhos ou agentes de transação no mercado, relações entre locador e locatário, membros de uma mesma comunidade local, vizinhos e coproprietários, até relações íntimas entre cônjuges, por exemplo.

Essa concepção quanto à variação do espectro de relações foi evidenciada por Singer (1988), que destacava que, ao invés de as pessoas relacionarem-se umas com as outras ou por meio de uma comunidade universal ou por meio de decisões individuais de contratar, as pessoas se relacionam das mais diversas formas. "Podemos entender as relações sociais compreendendo um espectro, de relações entre estranhos, a relações entre vizinhos, a manter relações no mercado, a relações íntimas na família"42 (SINGER, 1988, p. 654). Para ele essa forma de entender o social relativiza a distinção entre autonomia e comunidade.

Nós não nos relacionamos com os outros apenas por meio do mecanismo da comunidade como um todo ou por meio de acordos entre indivíduos autônomos. Mais que isso, nós podemos nos relacionar com outros de maneiras que não se encaixam em nenhuma dessas categorias extremas, mas mediante relações mais fluídas, relações constantes de dar e receber que são características das relações na família e nas associações ${ }^{43}$ (SINGER, 1988, p. 653).

Assim, inspirado no espectro de Singer $(1988)^{44}$, Dagan (2011) defende que a propriedade configura-se de diversas formas, correspondendo às várias interações humanas, ao amplo espectro de relações possíveis. Idealmente, as configurações da propriedade existentes tanto constroem quanto refletem interações ideais entre pessoas em determinadas categorias de relações e quanto a categorias específicas de recursos. "Por exemplo, diante da forma da propriedade de interesse comum das comunidades, tanto autonomia como

\footnotetext{
${ }^{41}$ Tradução livre de: "More specifically, our existing repertoire of property forms offers a tentative suggestion to parse the social world into distinct categories of human interaction" (DAGAN, 2011, p. 28).

${ }_{42}$ Tradução livre de: "We can understand social relationships as comprising a spectrum, from relations among strangers, to relations among neighbor, to continuing relations in the market, to intimate relations in the family" (SINGER, 1988, p. 654).

${ }^{43}$ Tradução livre de: "We do not relate to others only through the mechanism of whole community or through agreements between autonomous individuals. Rather, we can relate to others in ways that do not fit either of these polar categories, but through the more fluid, ongoing relationships of give and take that are characteristic of relations in the family and in associations" (SINGER, 1988, p. 653).

${ }^{44}$ Vale ressaltar aqui que Dagan (2011), embora inspirado no pensamento de Singer (1988), utiliza um espectro diverso de relações sociais. Dagan (2011) diverge de Singer (1988), sobretudo, porque este sugere que a confiança pode servir como parte do argumento para os direitos de propriedade, enquanto aquele defende que a confiança, por si só, é um terreno movediço para justificar esses direitos, sendo desejável apenas quando facilita algum bem ou valor humano (DAGAN, 2011, p. 28).
} 
comunidade formam sua essência, e, assim, a propriedade implica tanto direitos quanto responsabilidades" ${ }^{\prime 45}$ (DAGAN, 2011, p. 29).

Seguindo essa linha de raciocínio, Dagan (2011) complementa que a análise normativa recomendada pela abordagem realista da propriedade deve recorrer aos efeitos materiais do direito de propriedade no comportamento das pessoas, ao seu impacto constitutivo e expressivo, bem como à complexa interdependência dos dois efeitos (DAGAN, 2011).

Aqui, deve-se ter em mente a já mencionada tensão indissolúvel defendida pelos realistas entre poder e razão: o direito de propriedade, assim como o direito em geral, consiste em um mecanismo coercitivo apoiado pelo poder do Estado e, portanto, suas prescrições devem ser justificadas em termos de promover valores humanos. Por conseguinte, é necessário reavaliar as instituições da propriedade quanto à sua efetividade em promover os valores aceitos e, ainda, quanto à manutenção da validade e da conveniência desses valores. Essa reavaliação, por sua vez, explica a característica de provisoriedade das formas existentes, que se submetem, portanto, assim como o direito como um todo, a um constante processo de reverificação.

Referida investigação, explica Dagan (2011), requer um reexame crítico e construtivo da categorização jurídica existente das relações (e dos recursos), assim como dos valores que o direito de propriedade promove. Nesse ponto, o autor alerta, ainda, para o já mencionado fato de que os valores não se confundem com puras preferências, devendo ser defendidos a partir do exercício da razão e relacionando-se com os interesses e direitos humanos (DAGAN, 2011, p. 29).

Portanto, segundo Dagan (2011), a concepção da propriedade como instituições não pode ser entendida como um catálogo de "gravetos" (sticks) substantivos totalmente independentes entre si com um número infinito de permutações. Na construção da concepção, unificam-se ideais normativos para as categorias principais das relações interpessoais, que devem, assim, ser previamente estabelecidas e, por conseguinte, limitadas.

As formas da propriedade devem ser, portanto, quantitativamente limitadas e padronizadas. Por outro lado, como instituições que estruturam e canalizam relações humanas, não podem ser entendidas como formas “congeladas", mas, ao revés, estão sujeitas à mencionada reavaliação normativa e reconfiguração possível (DAGAN, 2011, p. XIII). Desse modo, coloca o autor que, para evitar o que chama de "armadilhas" de tomar como essencial o

\footnotetext{
${ }^{45}$ Tradução livre de: "For instance, with the property form of common interest communities, both autonomy and community are of the essence, and thus ownership implies both rights and responsibilities" (DAGAN, 2011, p. 29).
} 
repertório existente das formas da propriedade, deve-se evitar uma exagerada autoridade normativa proveniente dessas formas. Se a propriedade é entendida como instituições, o apelo a essas formas não precisa _ e nem pode ser _ a parte final da análise jurídica. Como já mencionado, essa abordagem demanda um constante processo _ e devidamente cauteloso _ de identificação dos valores humanos subjacentes às formas existentes de propriedade e à concepção do regime de governança a fim de promovê-los adequadamente.

Cada instituição da propriedade, pois, tem como objetivo, na sua própria maneira e com relação a alguma esfera de aplicação prevista, um conjunto de valores humanos que podem ser promovidos por suas regras constitutivas. Assim, as instituições da propriedade consolidam as expectativas das pessoas que saberão o que esperar quando ingressam em determinada relação, como, por exemplo, uma locação ou um casamento (DAGAN, 2011).

Desse modo, nessa concepção de propriedade, um conjunto de regras bastante precisas deve governar cada instituição para que as pessoas possam prever as consequências de diversas contingências futuras e, assim, planejar e estruturar suas vidas, afetando, ainda, suas ideias e preferências quanto a essas categorias de relações.

Nesse sentido, diferentemente do "feixe de gravetos", as instituições da propriedade, enquanto formas estabelecidas da propriedade com estruturas internas distintas, possuem dois papéis principais: consolidar expectativas e expressar formas ideais de relações. Ambos os papéis, por sua vez, demandam uma medida de estabilidade e, assim, segundo Dagan (2011), "para formar molduras efetivas de interação social e cooperação, o direito de propriedade pode reconhecer um número necessariamente limitado de categorias de relações e recursos" ${ }^{46}$ (DAGAN, 2011, p. 30). Para o autor, essa exigência de padronização corresponde também ao fato de que existe uma necessidade que obriga a limitação do número de instituições da propriedade, uma vez que o direito pode expressar efetivamente apenas uma quantidade determinada de categorias ideais de relacionamento interpessoal (DAGAN, 2011, p. 30).

Trata-se, pois, da ideia expressa pelo princípio chamado de numerus clausus, que limita a propriedade em número de formas identificáveis e padronizadas, entendido como um meio de facilitar as categorias de interação humana.

Para Dagan (2011), o referido princípio sustenta as instituições da propriedade como construtos sociais intermediários por meio dos quais o direito interage _ reflete e conforma com nossos valores sociais (DAGAN, 2011, p. 31).

\footnotetext{
${ }^{46}$ Tradução livre de: "[...] to form effective frameworks of social interaction and cooperation, property law can recognize a necessarily limited number of categories of relationships and resources" (DAGAN, 2011, p. 30).
} 
Conforme mencionado anteriormente, nos dias atuais, Merrill (2011), ao propor a representação da propriedade como um "prisma", também elucida a função do princípio do numerus clausus. Para ele, o princípio assume a tarefa de otimizar a padronização das formas relacionadas aos direitos de propriedade, a fim de garantir que as partes indiretamente afetadas tenham uma clara informação a respeito de seus direitos e deveres em face da relação jurídica entre proprietário e o que Merrill (2011) denomina de potenciais negociadores.

Merrill e Smith (2000) defendem que a limitação do número de propriedades reflete necessidades de eficiência: os direitos de propriedade devem ser bem definidos para que as partes possam proceder a negociações com baixos custos de transação, conhecidos também como custos externos ou externalidades. A relação entre definição de direito e custos de transação é, assim, a base da abordagem dita econômica a respeito do direito de propriedade e do princípio do numerus clausus.

Assim, Merrill e Smith (2000) introduzem uma nova perspectiva teórica a respeito da propriedade que enfatiza, sobretudo, os chamados "custos de informação". Os autores, vale destacar, desenvolvem uma versão específica da conhecida teoria dos custos de transação, que abarcam os custos de coleta de informações, negociação e execução. Argumentam, que, considerando que os direitos de propriedade são direitos oponíveis contra todos, a sua complexidade deve ser suficientemente limitada para que os custos de informação sobre eles não se tornem demasiadamente elevados para que funcionem de forma eficaz (MERRILL; SMITH, 2000). Vale ressaltar que, para essa linha de pensamento, o direito deve relutar em reconhecer novos direitos de propriedade, uma vez que as partes que criam esses direitos não conseguiriam considerar a totalidade dos custos incorridos por esses estranhos na determinação dos atributos desses novos direitos.

Apesar de também defender a ideia de padronização das formas da propriedade, a abordagem realista proposta por Dagan (2011) contrasta drasticamente à perspectiva daqueles autores no que se refere à justificação interna dessa limitação. A diferença dos posicionamentos, importa assinalar, não se limita ao seu aspecto teórico, mas possui importantes implicações práticas: se a economia da comunicação, argumenta Dagan (2011), é a razão para a limitação das formas da propriedade, assim, para conseguir esse benefício, deve-se tratar as formas da propriedade como conceitos com uma estrutura reconhecível e uma lógica interna independente. Isso pode ensejar, portanto, raciocínios dedutivos a partir de formas congeladas da propriedade, em detrimento de um raciocínio normativo e contextual, necessário para a garantia efetiva de valores humanos (DAGAN, 2011, p. 33). 
Nesse ponto, Dagan (2011) enfatiza que, em sua concepção realista, levar a sério as formas da propriedade existentes significa que, ao se desenvolver as regras acerca das várias teorias da propriedade, deve-se raciocinar a partir do propósito social daquela forma, ou seja, normativamente, e não dedutivamente conforme parece supor a teoria baseada nos custos de informação.

\begin{abstract}
Devemos abordar tais questões doutrinárias normativamente, mais que dedutivamente, uma vez que apenas o raciocínio normativo pode acentuar os benefícios das nossas instituições da propriedade. Essa forma de raciocínio não prejudica a relativa estabilidade das instituições da propriedade, porquanto as expectativas das pessoas relacionam-se mais com o "caráter" da instituição do que com suas regras precisas. E o "caráter" da instituição da propriedade é suficientemente estável desde que os propósitos da instituição e as categorias sociais a quais servem não sejam revisitados tão frequentemente ${ }^{47}$ (DAGAN, 2011, p. 3334).
\end{abstract}

Nesse sentido, as formas da propriedade assumem, na perspectiva realista, uma estabilidade relativa e desempenham um importante papel, uma vez que, como mencionado, consolidam as expectativas e expressam formas ideais de interações humanas. Assim, a configuração da propriedade a partir de instituições possibilita a representação e, por conseguinte, a proteção de várias categorias de interação humana, de modo a promover importantes valores humanos e, ao mesmo tempo, permitir relativa estabilidade e previsibilidade.

Ao tempo em que busca construir uma terceira alternativa para a propriedade, entre forma e substância, Dagan (2011) enfatiza que a metáfora do feixe de gravetos deve continuar a fazer parte da análise da construção do direito de propriedade. A referida análise atende à constatação da necessidade de um processo permanente de verificação e reverificação do direito, uma vez que nos capacita a reexaminar formas existentes, adicionar novas formas e reformular configurações da propriedade já presentes no ordenamento, sempre que essas formas não viabilizarem, de forma efetiva, a promoção de valores humanos.

Assim, pode-se concluir, adotando a perspectiva de Dagan (2011), que a propriedade deve ser abordada tanto como forma quanto como substância (forms and bundles). Como

\footnotetext{
${ }^{47}$ Tradução livre de: "We must address such doctrinal questions normatively rather than deductively because only normative reasoning can accentuate the benefits of our property institutions. This mode of reasoning does not undermine the relative stability of the institutions of property because people's expectations relate more to the "character" of an institution than to its precise rules. And the character of the institutions of property is sufficiently stable as long as the purpose of these institutions and the social categories they serve are not revisited too frequently" (DAGAN, 2011, p. 33-34).
} 
visto, trata-se, portanto, mais do que puras formas a serem interpretadas a partir de raciocínios dedutivos e independentes, ensejando consequências lógicas. E, ao mesmo tempo, mais do que desformes "gravetos" com infinitas possibilidades de permutações. Como instituições humanas que representam, as formas _ ou instituições _ da propriedade devem ser trabalhadas por meio de uma agregação que fortaleça sua conveniência normativa, considerando as características das categorias de relações e do contexto em que estão situadas e, por conseguinte, os valores a que devem servir (DAGAN, 2011, p. 35).

Tem-se, assim, nas palavras de Dagan (2011), que a noção de propriedade como um conjunto de instituições é tanto um olhar para o passado como um olhar para o futuro, de sorte a desafiar constantemente a conveniência dos pressupostos normativos das instituições da propriedade, sua capacidade de resposta ao contexto social em que estão situadas e sua efetividade na promoção de seus objetivos normativos examinados contextualmente. Essa abordagem realista é, assim, "um exercício de otimismo jurídico, uma tentativa de explicar e desenvolver as formas existentes de propriedade no sentido de acentuar sua conveniência normativa enquanto se mantém em sintonia com seu contexto social" ${ }^{\text {48 }}$ (DAGAN, 2011, p. $31)$.

Entende-se que, considerando a importância da concepção de propriedade e o papelchave que desempenha na sociedade, a noção ora trazida, de propriedade enquanto instituições, permite que seja conferida uma abordagem social e economicamente estratégica já na estruturação do conceito, conectando-o, ainda, a cada realidade em que estiver inserido e permitindo, assim, que a propriedade possa efetivamente promover a justiça social.

Assim, no que interessa ao presente trabalho e reconhecendo o importante papel da concepção realista ora abordada, há que se analisar as características presentes na relação que envolve a propriedade tutelada pela regularização fundiária das ocupações em áreas rurais de terras da União, no âmbito da Amazônia Legal. Como será visto, entende-se que, a partir dessa análise, é possível vislumbrar uma aproximação da visão do legislador à noção realista de propriedade e esboçar os propósitos normativos da legislação ao tratar dessa importante política pública, permitindo que sua aplicação não se distancie dos valores humanos a que essa instituição da propriedade deve servir.

\footnotetext{
${ }^{48}$ Tradução livre de: "The realist approach to property is thus an exercise in legal optimism, an attempt to explain and develop the existing property forms in a way that accentuates their normative desirability while remaining attuned to their social context" (DAGAN, 2011, p. 31).
} 


\section{A REGULARIZAÇÃo FUNDIÁRIA NO ÂMBITO DA AMAZÔNIA LEGAL E A PROTEÇÃO DA PROPRIEDADE}

\subsection{A legitimação de posse no Brasil: um breve panorama histórico do regime de terras}

Como já destacado, reconhecer a existência de formas diferentes de propriedade significa, nas palavras de Grossi (2006), recusar o caráter absoluto da propriedade moderna, uma visão individualista e potestativa, produto histórico de uma época (GROSSI, 2006). Entende-se, pois, que uma análise comprometida com o real significado da propriedade deve evitar uma perspectiva reducionista e admitir a existência de um complexo bastante amplo de situações jurídicas conformadas a partir da relação entre homens e coisas.

Assim como Dagan (2011), entendemos que a propriedade deve ser encarada como um conjunto de instituições, formas previamente estabelecidas que representam relações entre pessoas, constituídas a partir do vínculo com determinado recurso. Enquanto forma, portanto, a instituição da propriedade corresponde a uma moldura de dada interação interpessoal que consolida as expectativas das pessoas e expressa os ideais normativos do direito para o centro das relações humanas. Enquanto substância, cada instituição da propriedade tem como objetivo, no seu próprio modo e com relação a alguma esfera de aplicação prevista, um conjunto de valores humanos que podem ser promovidos por suas regras constitutivas.

Como visto, no ordenamento jurídico pátrio, já não prevalece a visão da propriedade como um direito absoluto, oponível a todos, reconhecendo-se sua finalidade social e seu importante papel dentro da sociedade. Entende-se que as disposições constitucionais e legais contidas no ordenamento a respeito da propriedade ajustam-se em grande medida à concepção elaborada por Dagan (2011), uma vez que a heterogeneidade própria do pluralismo de valores, presente em nossa sociedade e reconhecida juridicamente, implica a ideia de que diferentes valores ou diferentes equilíbrios devem orientar diferentes áreas do direito e da vida, refletindo-se, por conseguinte, na maneira como a propriedade é enxergada.

As instituições da propriedade expressam, assim, equilíbrios diversos entre esses valores, de acordo com o tipo de relação social a que se referem e com a natureza do recurso em jogo. Considerando a controversa convivência entre os diversos valores presentes na concepção de propriedade, entende-se que cabe, portanto, ao direito oferecer os princípios e as regras para a acomodação dessa "feliz pluralidade" (DAGAN, 2011, p. XVIII). 
Nesse sentido, seguindo a visão proposta por Dagan (2011), passaremos a abordar, como uma dessas manifestações da propriedade na vida real, a regularização fundiária das ocupações incidentes em terras da União, em áreas rurais, no âmbito da Amazônia Legal. Entende-se, como veremos, que o ordenamento, ao permitir que determinado indivíduo passe a ser proprietário de uma terra até então pública, contribui para a distribuição mais equânime de riqueza naquela região, bem como tutela importantes valores humanos presentes nessas relações. Por meio da referida regularização, atribuem-se não apenas direitos, mas responsabilidades aos ocupantes de terras públicas federais, tratando-se de um importante instrumento de legitimação de posse de ocupações, sobretudo por pequenos agricultores, cuja realidade é, em geral, de fragilidade econômica, baixa organização política e incapacidade de inserção de seus interesses na esfera pública.

Como será visto, a propriedade resultante da regularização fundiária naquela região reflete valores ligados à responsabilidade social, ao meio-ambiente, à autonomia, à comunidade e ao desenvolvimento econômico e sustentável dos Estados integrantes da Amazônia Legal.

Por sua vez, para subsidiar o estudo da propriedade e a interpretação do significado e dos propósitos da regularização fundiária, revela-se oportuna uma breve análise quanto à evolução do tratamento conferido pelo ordenamento jurídico ao processo de organização de terras no Brasil. Conforme destaca Varela (2005), a história da propriedade sesmarial é, antes, uma história de diversas formas de apropriação da terra, de múltiplas propriedades e múltiplos deveres, totalmente distinta da fórmula abstrata que caracteriza o direito da propriedade nas codificações liberais (VARELA, 2005, p. 121).

Assim, refletir sobre a regularização fundiária remete-nos ao resgate da memória territorial brasileira como uma forma de melhor compreender a multiplicidade do conceito e os propósitos normativos presentes na legislação que trata da matéria, o que, por conseguinte, contribui para que seja possível pensar na propriedade resultante da regularização fundiária na Amazônia Legal como uma instituição específica da propriedade, no sentido proposto por Dagan (2011). 


\subsubsection{O regime de sesmarias}

Com a colonização portuguesa, não obstante a existência de povos indígenas no Brasil, a propriedade do território foi transportada para além-mar, passando ao domínio da Coroa Portuguesa todas as terras recém descobertas.

A princípio, no território brasileiro, as sesmarias adquiriram o caráter de concessão administrativa sobre o domínio público com o encargo de cultivo. Tratava-se, pois, de uma concessão de propriedade sob condição resolutiva, o que significava que, se, em cinco anos, o proprietário não tivesse conferido uma destinação produtiva à terra, perderia sua propriedade (LIMA, 1990).

Todavia, em terras brasileiras, o instituto das sesmarias deparou-se com uma realidade distinta, sofrendo significativas alterações. Em Portugal, utilizavam-se as concessões com a finalidade de exploração de terras abandonadas no período das navegações, as quais permaneciam sob a supervisão de representantes do rei, com o poder de retirá-las de quem não as aproveitasse de acordo com as regras estabelecidas. Surge com o objetivo de combater uma aguda crise de abastecimento, declínio demográfico e consequente escassez de mão-de-obra acentuada pela Grande Peste que assolara a Europa no ano de 1348 (VARELA, 2005, p. 21).

No Brasil, porém, o contexto era diverso. Pressuposto básico para a compreensão da propriedade sesmarial brasileira é, precisamente, segundo Varela (2005), a sua natureza pública, ou seja, "o fato de os territórios pertencerem de jure à Coroa, sob a jurisdição espiritual da Ordem de Cristo" (VARELA, 2005, p. 73). As motivações da realidade colonial, na qual se buscará viabilizar a produção em terras virgens ${ }^{49}$, conduziriam, contudo, a transformações do sistema de sesmarias, transportado para uma realidade totalmente diferente daquela em que fora concebido.

Em primeiro lugar, a escolha da fórmula jurídica encobre a exclusão da população indígena local, uma vez que não havia exatamente terras abandonadas, considerando a ocupação dos espaços por comunidades indígenas centenárias. Ademais, conforme destaca Varela (2005), são pressupostos para a compreensão adequada desse fenômeno, denominado pela autora de "transplante jurídico", as bases da política mercantilista que direciona as relações econômicas entre metrópoles europeias e colônias americanas. Isso porque, nas colônias, cenário de saques e exploração, “as estruturas que se organizavam para atender à

\footnotetext{
${ }^{49}$ Varela (2005) assinala que "terras virgens" significa "virgens de anterior ocupação portuguesa, considerando que já haviam sido ocupadas pela população indígena local” (VARELA, 2005, p. 77).
} 
demanda da generalização de mercadorias são, fundamentalmente, o latifúndio, núcleo da agricultura voltada à exportação, e a utilização da mão-de-obra escrava" (VARELA, 2005, p. 78-79). A esse respeito, Varela (2005) ainda assinala que a renda do escravo é tida como a categoria econômica fundamental nesse contexto, "onde a propriedade de escravos tem maior importância do que a possessão de terras, pois é o que instrumentaliza a produção, além de exigir valioso investimento por parte do senhor (enquanto que a terra era doada gratuitamente pela Coroa Portuguesa)" (VARELA, 2005, pp. 79-80). Assim, complementa a autora que, muitas vezes, possuir escravos seria condição para receber terras de sesmarias, não beneficiando, portanto, trabalhadores ou cultivadores eventuais, mas aqueles já dotados de posses e riqueza (VARELA, 2005, p. 82).

A respeito das peculiaridades que o sistema sesmarial brasileiro apresentava, Faoro (2009) ressalta que a sesmaria perde o caráter administrativo que lhe fora infundido pela legislação portuguesa e passa a acentuar seu conteúdo dominial, gerando, a despeito de seus propósitos iniciais, a grande propriedade.

\begin{abstract}
Depois de perder o caráter administrativo que lhe fora infundido pelos legisladores de Portugal, para acentuar seu conteúdo dominial, o regime das sesmarias gera, ao contrário de seus propósitos iniciais, a grande propriedade. Para chegar a essas linhas de contorno, muito se deve ao influxo da escravidão e ao aproveitamento extensivo da pecuária, fatores que se aliam ao fato de que, para requerer e obter a sesmaria, era necessário o prévio prestígio político, confiada a terra não ao cultivador eventual, mas ao senhor dos cabedais ou titular de serviços públicos. A propriedade seria, desta sorte, uma afirmação aristocrática, para uma grande empresa ou para o domínio de lavradores e vaqueiros (FAORO, 2009, p. 464).
\end{abstract}

Para Faoro (2009), “tantas foram as liberalidades nas concessões de sesmarias, com áreas de dez, vinte e até cem léguas, com diversas doações a um mesmo requerente, que, em 1822, não havia mais terras a distribuir" (FAORO, 2009, p. 464). Assim, como observa o autor, após a distribuição das sesmarias, definiu-se um quadro em que a grande propriedade tomou conta do Brasil, com a dependência e o entrave da ascensão do lavrador que não era proprietário das terras.

A sesmaria não serve ao cultivo e ao aproveitamento, mas imobiliza o status do senhor de terras, utilizada menos em proveito da agricultura do que da expansão territorial, estimulada esta pelos agentes do rei no Brasil. O fim do regime das sesmarias estava, mesmo antes da Resolução de 17 de julho de 1822, decretado pelos fatos _ a exaustão dos bens a distribuir fecha um período histórico (FAORO, 2009, p. 465). 
Desse modo, não obstante sua natureza de concessão administrativa de caráter resolutivo, a distribuição de sesmarias estruturou as bases para a evolução do regime jurídico da propriedade privada no Brasil. Conforme destaca Lima (1990), o regime das sesmarias, a despeito de sua natureza formal de concessão administrativa com o encargo de cultivo em benefício da agricultura, representou "verdadeira doação de domínios régios, a que só a generosidade dos doadores serve de regra" (LIMA, 1990, p. 41). Nesse sentido, o autor complementa:

\begin{abstract}
Não é de esquecer, no entanto, o modo por que a população colonial se estabeleceu no nosso território, obedecendo, não a um plano de distribuição geográfica predeterminado, mas ao arbítrio e à conveniência individual. Este abandono a si próprio do nosso colono, para a escolha de sua sede territorial, nascido das falhas e deficiências da administração portuguesa, tinha, forçosamente, que refletir-se sobre a propriedade, em que somente a aquisição jure occupationis podia fazer-lhes pendant. Assenhorar-se de um pedaço de terra e cultivá-lo, além de tudo, devia, para os nossos colonizadores, ser preferível a correr a hierarquia da administração até ao governador e, depois até ao rei, a fim de obter uma concessão de sesmaria. As concessões de sesmarias, na maioria dos casos, restringiam-se, portanto, aos candidatos a latifúndios, que, afeitos ao poder, ou ávidos de domínios territoriais, jamais, no entanto, poderiam apoderar-se das terras que desejavam para si (LIMA, 1990, p. 41).
\end{abstract}

Durante cerca de três séculos, a propriedade permaneceu sob o domínio da Coroa Portuguesa e as sesmarias, assim como as datas ${ }^{50}$, foram outorgadas com a finalidade de financiar a colonização do nosso país. Entretanto, quanto mais Portugal negligenciava a gestão territorial da colônia, mais o caráter dominial do regime de sesmarias se acentuava, favorecendo interesses privados dos poderosos beneficiários, em detrimento dos pequenos agricultores, verdadeiros responsáveis pelo cultivo da terra.

Com o fim do regime das sesmarias, instaurou-se o chamado "regime das posses", período em que se legitimou o costume jurídico, passando a posse com cultura efetiva a ser reconhecida como um modo legítimo de aquisição da propriedade, conforme será visto a seguir.

\footnotetext{
${ }^{50}$ Explica Varela (2005) que "[d]istinguem-se as sesmarias das datas de terras sendo estas as concessões feitas pelos comandantes militares, em geral não maiores do que meia légua quadrada (2.178 ha), enquanto que as primeiras eram concedidas pelos governadores de capitanias e vice-reis do Brasil, aos "candidatos a latifúndio"” (VARELA, 2005, p. 74).
} 


\subsubsection{O regime de posses}

Nos termos destacados por Lima (1990), o colono, submetido às contingências econômicas criadas pelas concessões que geraram os grandes latifúndios, "afastou a ficção da propriedade estatal, que se atravessava entre ele e a terra, e pela posse e pelo cultivo, desde logo, se investiu nessa mesma propriedade que, a homens de sua condição, sabia estar, de antemão destinada" (LIMA, 1990, pp. 57-58). A posse, portanto, mesmo antes do fim do regime sesmarial, já era uma prática comum nas terras brasileiras, embora não reconhecida juridicamente.

Diante do colapso do regime de sesmarias, o qual ensejou o distanciamento da propriedade de sua posse efetiva, foi estabelecida a Provisão Real de 14 de março de 1822, que determinou que as medições e demarcações fossem feitas "sem prejudicar quaesquer possuidores que tenhão effectivas culturas no terreno, porquanto devem elles ser conservados nas suas posses, bastando para títulos a reaes ordens, por que as mesmas posses prevaleção ás sesmarias posteriormente concedidas" (apud LIMA, 1990, p. 52). Sinalizava-se, assim, em direção à proteção das ocupações estabelecidas.

Conforme já mencionado, em virtude da exaustão dos bens a distribuir, o regime sesmarial já estava, pelos fatos, encerrado. Por sua vez, a formalização do fim desse regime sobreveio com a Resolução $n^{\circ} 76$, de 17 de julho de 1822:

\footnotetext{
RESOLUÇÃO No 76 - REINO - DE CONSULTA DA MESA DO DESEMBARGO O PAÇO DE 17 DE JULHO DE 1822.

Manda suspender a concessão de sesmarias futuras até a convocação da Assembléia Geral Constituinte.
}

Foi ouvida a Mesa do Desembargo do Paço sobre o requerimento em que Manoel José dos Reis pede ser conservado na posse de terras em que vive há mais de 20 anos com a sua numerosa família de filhos e netos, não sendo jamais as ditas terras compreendidas na medição de algumas sesmarias que se tenham concedido posteriormente.

Responde o Procurador da Coroa e Fazenda: não é competente este meio. Deve portanto instaurar o suplicante novo requerimento pedindo por sesmaria as terras de que trata, e de que se acha de posse; e assim se deve consultar.

Parece à Mesa o mesmo que ao Desembargador Procurador da Coroa e Fazenda, com que se conforma. Mas a $V^{a}$ Real Resolverá o que houver por bem.

Rio de Janeiro, 8 de julho de 1822.

Resolução 
Fique o suplicante na posse das terras que tem cultivado e suspendam-se todas as sesmarias futuras até a convocação da Assembléia Geral, Constituinte e Legislativa.

Paço, 17 de julho de 1822.

Com a rubrica de S. A. Real o Príncipe Regente.

José Bonifácio de Andrada e Silva (BRASIL, 1822).

Destaca Varela (2005) o caos do cenário da distribuição territorial que a nova legislação agrária pretenderia organizar, na segunda metade do século XIX. "Tratava-se de um grande número de sesmarias não demarcadas, nem registradas, nem confirmadas; igualmente significativa era a quantidade de simples 'posses', prática comum que se firmou paralelamente aos trâmites burocráticos exigidos para as doações de sesmarias" (VARELA, 2005, p. 108).

Vale mencionar que a extinção do regime de sesmarias ocorre em um cenário de início da expansão da economia cafeeira e do movimento de independência, contexto que, juntamente com a crise do trabalho escravo, estimulou a valorização da terra e o processo de organização da propriedade privada (VARELA, 2005, p. 111).

Por sua vez, com o fim do regime das sesmarias, instaurou-se o que Lima (1990) denomina de "regime das posses", período em que se legitimou o costume jurídico, passando a posse com cultura efetiva a ser reconhecida como um modo legítimo de aquisição do domínio: "em lugar dos favores do poder público, a terra passa a ser adquirida pela herança, pela doação, pela compra e, sobretudo, pela ocupação - a posse, transmissível por sucessão e alienável pela compra e venda" (FAORO, 2009, p. 465).

\footnotetext{
Apoderar-se de terras devolutas e cultivá-las tornou-se cousa corrente entre nossos colonizadores, e tais proporções essa prática atingiu que pôde, com o correr dos anos, vir a ser considerada como modo legítimo de aquisição do domínio, paralelamente a princípio, e, após, em substituição ao nosso tão desvirtuado regime das sesmarias (LIMA, 1990, p. 51).
}

É possível observar que o reconhecimento e a tutela da situação fática da ocupação aproxima o direito da realidade e do interesse social, democratizando, pela primeira vez, na história territorial brasileira, o acesso à propriedade, o que, até então, pertencia ao Estado.

Entretanto, em pouco tempo, a ideia da posse humilde com cultura efetiva passou a se impregnar do espírito latifundiário que a própria legislação das sesmarias havia difundido e fomentado (LIMA, 1990, p. 58). "Os dois meios - a sesmaria e a posse - depois de coexistirem, se concentram na ocupação, o início forma de pressão nos latifúndios do lavrador 
humilde, grande e pequena propriedade, depois o processo de constituir latifúndio" (FAORO, 2009, p. 465).

Assim, não obstante a cultura efetiva figurasse como o requisito do reconhecimento da posse, segundo o novo regime, o posseiro, a partir da sua lavoura, estendia a terra até o ponto em que a resistência de terceiros não obstasse suas pretensões territoriais. "De um modo ou de outro, a grande propriedade era o objetivo já fixado na imaginação social" (FAORO, 2009, p. 465).

Por seu turno, com a Constituição Imperial de 1824 (BRASIL, 1824), o direito de propriedade passa a ser garantido em sua plenitude, trazendo, como única exceção a esse caráter absoluto, o uso em prol do "bem público legalmente verificado". Importa-se, assim, para o ordenamento pátrio, a concepção da propriedade moderna, marcada pelo individualismo, que, como já ressaltado, por muito tempo integrou a cultura jurídica brasileira.

\begin{abstract}
Art. 179. A inviolabilidade dos Direitos Civis, e Politicos dos Cidadãos Brazileiros, que tem por base a liberdade, a segurança individual, e a propriedade, é garantida pela Constituição do Imperio, pela maneira seguinte. [...] XXII. E'garantido o Direito de Propriedade em toda a sua plenitude. Se o bem publico legalmente verificado exigir o uso, e emprego da Propriedade do Cidadão, será elle préviamente indemnisado do valor della. A Lei marcará os casos, em que terá logar esta unica excepção, e dará as regras para se determinar a indemnisação (BRASIL, 1824).
\end{abstract}

A Constituição de 1824 (BRASIL, 1824) traz, ainda, a previsão quanto à promulgação de uma lei regulamentando a ocupação de terras no Brasil, que veio a ser a Lei $\mathrm{n}^{\circ} 601$, de 18 de setembro de 1850, a chamada Lei de Terras (BRASIL, 1850).

Percebe-se, assim, que a extinção do regime sesmarial e a instituição do chamado regime de posses é um passo importante no processo de organização da propriedade privada da terra, que se consolida com a Lei de 1850 e, posteriormente, com o Código Civil de 1916 (VARELA, 2005, p. 111).

\title{
3.1.3 A Lei de Terras e a legitimação de posse
}

A Lei de Terras, Lei ${ }^{\circ}$ 601, de 1850 (BRASIL, 1850), é conhecida como a primeira lei a abordar a regularização de terras públicas cultivadas que constituíssem a "morada habitual" do posseiro. 


\begin{abstract}
Art. $5^{\circ}$ Serão legitimadas as posses mansas e pacificas, adquiridas por occupação primaria, ou havidas do primeiro occupante, que se acharem cultivadas, ou com principio de cultura, e morada, habitual do respectivo posseiro, ou de quem o represente, guardadas as regras seguintes: $\S 1^{\circ}$ Cada posse em terras de cultura, ou em campos de criação, comprehenderá, além do terreno aproveitado ou do necessario para pastagem dos animaes que tiver o posseiro, outrotanto mais de terreno devoluto que houver contiguo, comtanto que em nenhum caso a extensão total da posse exceda a de uma sesmaria para cultura ou criação, igual ás ultimas concedidas na mesma comarca ou na mais vizinha. $\S 2^{\circ}$ As posses em circumstancias de serem legitimadas, que se acharem em sesmarias ou outras concessões do Governo, não incursas em commisso ou revalidadas por esta Lei, só darão direito á indemnização pelas bemfeitorias. Exceptua-se desta regra o caso do verificar-se a favor da posse qualquer das seguintes hypotheses: $1^{\mathrm{a}}$, o ter sido declarada boa por sentença passada em julgado entre os sesmeiros ou concessionarios e os posseiros; $2^{a}$, ter sido estabelecida antes da medição da sesmaria ou concessão, e não perturbada por cinco annos; $3^{\mathrm{a}}$, ter sido estabelecida depois da dita medição, e não perturbada por 10 annos. $\S 3^{\circ}$ Dada a excepção do paragrapho antecedente, os posseiros gozarão do favor que lhes assegura o $\S 1^{\circ}$, competindo ao respectivo sesmeiro ou concessionario ficar com o terreno que sobrar da divisão feita entre os ditos posseiros, ou considerar-se tambem posseiro para entrar em rateio igual com elles. $\S 4^{\circ}$ Os campos de uso commum dos moradores de uma ou mais freguezias, municipios ou comarcas serão conservados em toda a extensão de suas divisas, e continuarão a prestar o mesmo uso, conforme a pratica actual, emquanto por Lei não se dispuzer o contrario (BRASIL, 1850).
\end{abstract}

Varela (2005) assinala o contexto de transição no qual se insere a Lei de 1850, destacando a transição do trabalho escravo ao trabalho livre, bem como a transição de uma determinada organização jurídica da terra a outra. Assim, como verdadeiro divisor de águas, constata a autora que, de um lado, a Lei de 1850 procura legitimar as apropriações anteriores, a partir do critério do efetivo cultivo; e, de outro, instituir novas regras "para que o Estado tomasse as rédeas do desordenado processo de apropriação do território e controlasse a colonização" (VARELA, 2005, p. 139).

Conforme destaca Faoro (2009), não havia mais a possibilidade, ao dono da sesmaria, de expulsar os posseiros, considerando "os riscos da revolução social que isso geraria" (FAORO, 2009, p. 465). Assim, para o autor, a única solução "capaz de se impor, dada a importância do lavrador assentado sobre a ocupação, seria o reconhecimento da posse, com a extensão reduzida 'à de uma sesmaria para cultura ou criação igual às últimas concedidas na mesma comarca ou nas mais vizinhas", nos termos da previsão da Lei de Terras (FAORO, 2009, pp. 465-466). Para o futuro, assinala Faoro (2009), colocava-se fim ao regime das posses, admitida a transmissão da propriedade apenas pela sucessão e pela compra e venda, restando proibido, por sua vez, o reconhecimento de novas ocupações.

Graças à lei, a propriedade particular se extremou da terra devoluta, gozando a primeira, além de um título certo para a garantia de sua empresa, de um registro paroquial, embrião capaz de separar o senhor da terra do mero pretendente ao 
usucapião. Para o futuro as terras públicas só seriam adquiridas por meio da compra, com a extinção do regime anárquico das ocupações. Sobre esse estatuto se fixou a disciplina administrativa das terras, com a presença do poder público nas medições, completado com a reforma hipotecária de 1864. Uma inspiração mal esboçada continha ainda a Lei de 1850: a possibilidade de estimular, por seus preceitos, a colonização, com o imigrante adquirindo o chão de seu cultivo. Nesse campo, sombreado pela ineficiência de seus dispositivos, o estatuto territorial conserva, no regime da concessão, a velha energia sesmarial tradicional, que atribui ao Estado o objetivo do povoamento produtivo, com a propriedade particular comprometida a um fim, sem o cumprimento do qual reverte à sua origem (FAORO, 2009, p. 466).

Nesse sentido, observa Varela (2005) que, no processo de transição da forma concessionária à forma jurídica plena da propriedade territorial, "buscar-se-á, em aparente paradoxo, um mesmo e velho elemento: o cultivo" (VARELA, 2005, p. 154). O cultivo, portanto, passa a ser o critério para demarcar a distinção entre terras devolutas e aquelas que serão asseguradas aos seus senhores com o caráter de inviolabilidade (VARELA, 2005, p. 154).

Assim, com o regime criado pela Lei de Terras (BRASIL, 1850), surge a figura da legitimação da posse. Admitindo-se, como legítima e, por conseguinte, passível de proteção estatal, a posse daqueles que preenchessem os requisitos legais, os imóveis regularizados seriam, então, retirados do patrimônio público e reconhecidos como propriedade privada.

Entretanto, com a proibição da ocupação de terras pela Lei de 1850 (BRASIL, 1850), criminalizando o apossamento e definindo um preço mínimo para a compra da propriedade, o cultivo, que foi fundamento da instauração de uma nova ordem proprietária, deixa de ser elemento do direito nessa nova ordem estabelecida. Após a publicação da Lei, o critério da cultura efetiva não mais poderia ser utilizado para penalizar senhores de terras, conferindolhes, agora sim, uma propriedade absoluta e incondicionada, em consonância com o modelo jurídico abstrato e pleno da propriedade privada, inspirado no ideário jurídico liberal e arraigado, por muito tempo, à cultura jurídica brasileira (VARELA, 2005, p. 156-157).

Faoro (2009) ressalta, ainda, que, não obstante a "boa intenção" do legislador, inspirado pelo povoamento e colonização, a referida legislação surgiu de forma tardia, não logrando compensar, pela pequena propriedade, “o rumo expansionista do latifúndio" (p. 468). Os pequenos posseiros continuaram a ocupar uma posição de subordinação, na medida em que prevalecia a concentração de riqueza nas mãos dos grandes proprietários.

Em que pese as boas intenções, essa legislação veio tarde demais. Não obstante a resistência encarniçada e, às vezes, altiva dos pequenos posseiros, estes não podiam sustentar por muito tempo a luta com os poderosos adversários possuindo relações no Rio de Janeiro, recursos abundantes para pagar advogados, e os lazeres necessários para fazerem viagens à sede do município. Conquanto subsistissem ainda 
grande número de posseiros, de 1830 a 1850 e mesmo mais tarde, tornou-se sua posição gradativamente subalterna, na medida em que a riqueza do município se concentrava nas mãos dos proprietários de grande lavoura. Prensados entre as grandes fazendas, dedicaram os pequenos sitiantes suas atividades à produção de mantimentos (FAORO, 2009, p. 467).

De todo modo, ainda assim, a Lei de Terras (BRASIL, 1850) representa a inauguração, no ordenamento jurídico pátrio, da legitimação da posse, que, ao longo dos anos, foi tratada por inúmeros diplomas legais, de diferentes formas. O critério do cultivo, como observa Varela (2005), como diferenciador entre a propriedade pública e a privada implica, portanto, a atribuição de conteúdo à propriedade particular, "e de diversas graduações no interior desta: a propriedade do sesmeiro que de fato cultiva, a do sesmeiro que não cultiva, a do possuidor não-sesmeiro que cultiva etc" (VARELA, 2005, p. 162).

A partir dessa possibilidade de legitimação da posse, autorizada pela Lei de 1850 (BRASIL, 1850), observa-se, portanto, uma ideia de propriedade conectada à realidade vigente à época, servindo ao interesse social aliado à utilidade e à produção da terra, a partir da exigência legal de requisitos como o cultivo e a morada habitual. É possível vislumbrar aqui, pois, como muito bem pontuado por Varela (2005), indícios de uma visão preocupada com o conteúdo da propriedade, ou seja, com a substância da concepção, muito embora, posteriormente, o ordenamento passe a priorizar, exclusivamente, a forma do instituto.

Com base na Lei de Terras (BRASIL, 1850), reconhece-se, assim, a partir de uma situação de fato, um direito a ser assegurado pelo ordenamento, aproximando o modelo jurídico da sesmaria, até então frio e abstrato, à realidade social. Tal como a concepção ora defendida, da propriedade conectada à realidade e às reais necessidades da sociedade como um todo, é possível verificar que a referida legislação demonstra, de certa forma, uma preocupação com valores sociais, reconhecendo o importante papel social da propriedade.

Com o passar do tempo, verifica-se, porém, a consolidação da ruptura: "elemento de permanência o fundamento do cultivo é, aos poucos, na transição para o modelo de propriedade absoluta, deixado de lado" (VARELA, 2005, p. 162). Na estruturação de um modelo jurídico absoluto e pleno, o distanciamento do critério do cultivo apresenta-se como consequência lógica em consonância com a importada doutrina europeia e seu esforço máximo de abstração. "Alijado o cultivo das definições legais, aberto está o caminho para um conceito abstrato, unitário, do direito de propriedade" (VARELA, 2005, p. 163). Ao longo do tempo, pois, a concepção de propriedade, assumindo um viés individualista e potestativo, passou a priorizar a forma, em detrimento do conteúdo. 
A legitimação da posse representa, por sua vez, o caminho inverso, a retomada do cultivo e de outros elementos caracterizadores da propriedade como determinantes para que seja conferida a devida tutela estatal. Trata-se, assim, da proteção do conteúdo da propriedade, ou seja, do reconhecimento jurídico das relações de fato existentes a partir do vínculo entre o homem e a coisa, convergindo com os princípios e valores que inspiram a atual Constituição Federal, bem como com a visão proposta por Dagan (2011), que confere importância tanto à forma quanto à substância do instituto.

Nesse sentido, em consonância com a adoção pelo ordenamento jurídico pátrio _ após a Constituição Federal de 1988 (BRASIL, 1988), cujos princípios fornecem as bases das disposições do Código Civil de 2002 (BRASIL, 2002) _ de uma visão social e múltipla da propriedade, encontram-se diplomas legais ${ }^{51}$ que preveem a legitimação da posse, reconhecendo, nessa circunstância fática, valores humanos inerentes à noção de propriedade, merecedores, portanto, de proteção jurídica. A Lei $\mathrm{n}^{\mathrm{o}} 11.952$, de 25 de junho de 2009 (BRASIL, 2009d), insere-se dentre esses diplomas e, no âmbito da Amazônia Legal, cuida da legitimação das ocupações incidentes em terras públicas federais, em áreas rurais e urbanas.

O presente trabalho, por sua vez, aborda a análise da mencionada Lei, especificamente quanto à regularização das ocupações incidentes em terras da União situadas nas áreas rurais, no âmbito da Amazônia Legal. Procura-se demonstrar, a partir dessa análise, que o legislador conferiu um tratamento bastante específico e contextual a essa forma de propriedade, o que, a nosso ver, ajusta-se à visão proposta por Dagan (2011), acerca da necessidade de que a propriedade seja abordada a partir de categorias mais estreitas a fim de que atenda, efetivamente, a ideais de justiça e equidade. Conforme assinala o autor, a partir da consideração dessas categorias menores, permite-se que a propriedade, ou cada instituição que integra esse conceito, tenha como objetivo, no seu próprio modo e com relação a alguma

\footnotetext{
${ }^{51}$ Cita-se aqui, a título de ilustração: (i) o Estatuto da Terra (Lei n ${ }^{\circ} 4.504$, de 1964), que, em seu artigo 98, prevê que "[t]odo aquele que, não sendo proprietário rural nem urbano, ocupar por dez anos ininterruptos, sem oposição nem reconhecimento de domínio alheio, tornando-o produtivo por seu trabalho, e tendo nele sua morada, trecho de terra com área caracterizada como suficiente para, por seu cultivo direto pelo lavrador e sua família, garantir-lhe a subsistência, o progresso social e econômico, nas dimensões fixadas por esta Lei, para o módulo de propriedade, adquirir-lhe-á o domínio, mediante sentença declaratória devidamente transcrita" (BRASIL, 1964), (ii) a Lei n 6.383, de 1976, que prevê, em seu art. 29, que "[o] ocupante de terras públicas, que as tenha tornado produtivas com o seu trabalho e o de sua família, fará jus à legitimação da posse da área contínua até 100 (cem) hectares, desde que preencha os seguintes requisitos: [...]” (BRASIL, 1976); e (iii) a Lei $\mathrm{n}^{\circ}$ 11.977, de 2009, que dispõe, dentre outros pontos, sobre a regularização fundiária de assentamentos em área urbana e assim estabelece no art. 46: "A regularização fundiária consiste no conjunto de medidas jurídicas, urbanísticas, ambientais e sociais que visam à regularização de assentamentos irregulares e à titulação de seus ocupantes, de modo a garantir o direito social à moradia, o pleno desenvolvimento das funções sociais da propriedade urbana e o direito ao meio ambiente ecologicamente equilibrado" (BRASIL, 2009e).
} 
esfera de aplicação prevista, um conjunto de valores humanos que podem ser promovidos por regras constitutivas específicas (DAGAN, 2011).

Nesse sentido, a propriedade deve ser encarada como um conjunto de relações interpessoais, inseridas em contextos específicos e enquadráveis em formas previamente estabelecidas pelo ordenamento, visão essa que pode ser encontrada nas previsões contidas na Lei ${ }^{\circ}$ 11.952, de 2009 (BRASIL, 2009d), ao estabelecerem os requisitos e as condições para a conformação da propriedade resultante da regularização fundiária. Entende-se que, em consonância com a concepção ora defendida, a referida Lei, de certo modo, prevê uma moldura das interações provenientes das ocupações de terras públicas federais na Amazônia Legal, consolidando expectativas e expressando ideais normativos do direito para o centro das relações humanas.

Sob esses aspectos, passa-se, então, no presente capítulo, a analisar a regularização fundiária na Amazônia Legal, sua importância na sociedade e as características específicas que nos levam a crer na possibilidade de enquadrar o resultado desse processo como uma forma específica e contextualizada de propriedade.

\subsection{A regularização fundiária na Amazônia Legal}

Atualmente, o artigo 98 do Código Civil define bens públicos como "os bens do domínio nacional pertencentes às pessoas jurídicas de direito público interno" estabelecendo, ainda, que "todos os outros são particulares, seja qual for a pessoa a que pertencerem" (BRASIL, 2002). Quanto à alienação desses bens, o artigo 100 do diploma civilista dispõe que "[o]s bens públicos de uso comum do povo e os de uso especial são inalienáveis, enquanto conservarem a sua qualificação, na forma que a lei determinar" ${ }^{\prime 52}$ (BRASIL, 2002). Por sua vez, os bens denominados dominicais ${ }^{53}$, aqueles não destinados a uma finalidade comum ou

\footnotetext{
${ }^{52}$ Recorda-se, aqui, que os bens públicos de uso comum do povo são aqueles que se destinam à utilização geral pelos indivíduos, como os rios, os mares, as estradas, as ruas e as praças (artigo 99, I, do Código Civil (BRASIL, 2002)). Já os de uso especial são, por sua vez, aqueles voltados à execução dos serviços administrativos e dos serviços públicos em geral, como edifícios públicos, hospitais, universidades e quartéis (CARVALHO FILHO, 2006, pp. 943-944). Segundo Carvalho Filho (2006), "a denominação não é muito precisa, mas indica que tais bens [públicos de uso especial] constituem o aparelhamento material da Administração para atingir os seus fins" (2006, p. 944).

${ }^{53}$ A noção de bem dominical, conforme destaca Carvalho Filho (2006) é residual, "porque nessa categoria se situam todos os bens que não se caracterizem como de uso comum do povo ou de uso especial" (2006, p. 945). O autor complementa: "são bens dominicais as terras sem destinação pública específica (entre elas, as terras devolutas), os prédios públicos desativados, os bens móveis inservíveis e a dívida ativa" (CARVALHO FILHO, 2006, p. 945).
} 
especial, são passíveis de alienação ${ }^{54}$, o que, em regra, deve ocorrer mediante licitação prévia, nos termos da Lei $\mathrm{n}^{\circ}$ 8.666, de 1993 (BRASIL, 1993b). Vale lembrar, ainda, que bens públicos, afetados ou não, não são passíveis de serem adquiridos por usucapião, disposição contida no artigo $183, \S 3^{\circ}$, da Constituição Federal (BRASIL, 1988).

Assim, em linhas gerais, observa-se que a regra, no ordenamento jurídico brasileiro, é no sentido de que a alienação de bens imóveis da União ocorrerá apenas quanto àqueles não destinados e dependerá de autorização legislativa, avaliação prévia e licitação ${ }^{55}$. Diferentemente, a regularização fundiária de ocupações de terras públicas federais em áreas rurais na Amazônia Legal permite, se preenchidos os requisitos, a alienação do imóvel, de forma gratuita ou onerosa, dispensado o prévio procedimento licitatório. Trata-se, pois, de uma exceção à regra, que privilegia, conforme será visto, aquele que já ocupa e confere uma utilização apropriada ao imóvel, até então, público.

Como abordado anteriormente, no Brasil, a forma de distribuição da propriedade, vinculada, em sua origem, à combinação entre propriedade da Coroa Portuguesa e concessões de terras, levou à acumulação formal de terras em poder do Estado, gerando uma série de conflitos. Na região da Amazônia, esses conflitos foram agravados pela existência de diferentes comunidades locais, como, por exemplo, de índios, quilombolas e colonos, bem como pelo isolamento em que a área permaneceu durante muitos séculos.

\begin{abstract}
A Amazônia permaneceu durante muitos séculos uma região isolada do resto do Brasil, constituindo durante boa parte do período colonial uma unidade jurídica diretamente vinculada a Portugal. Desde o começo sua identidade oscilou entre realidades contrastantes chegando a ser denominada de inferno verde, pela dificuldade de se ter acesso à mesma e pelas condições de vida que não favoreciam os colonizadores (TRECCANI, 2001, p. 18).
\end{abstract}

Conforme destaca Treccani (2001), desde o início da ocupação na Amazônia, os grupos sociais que se instalaram na região assumiram posturas diversas: os índios e caboclos, que, segundo o autor, preocupavam-se com a conservação da flora e da fauna, assumiram, na prática, um projeto de desenvolvimento considerando a biodiversidade da região; e os

\footnotetext{
${ }^{54}$ Art. 101 do Código Civil. Os bens públicos dominicais podem ser alienados, observadas as exigências da lei (BRASIL, 2002).

${ }^{55}$ Art. 17, I, da Lei n ${ }^{\circ}$ 8.666, de 1993. A alienação de bens da Administração Pública, subordinada à existência de interesse público devidamente justificado, será precedida de avaliação e obedecerá às seguintes normas: I quando imóveis, dependerá de autorização legislativa para órgãos da administração direta e entidades autárquicas e fundacionais, e, para todos, inclusive as entidades paraestatais, dependerá de avaliação prévia e de licitação na modalidade de concorrência, dispensada esta nos seguintes casos: [...] (BRASIL, 1993b).
} 
colonizadores, "os de ontem e de hoje, saquearam suas riquezas e transformaram suas terras em butim" (TRECCANI, 2001, p. 18).

Atualmente, juntamente com as peculiaridades da região, constata-se que a indefinição dos direitos fundiários na Amazônia representa mais um entrave ao avanço de políticas de desenvolvimento sustentável na região. Essa situação foi verificada por Alston, Libecap e Mueller (2000), que relataram o clima de tensão e incerteza no ambiente institucional da Amazônia Legal.

\begin{abstract}
Na Amazônia Legal, o ambiente institucional que surgiu resulta em confusão, incentivos conflitantes e perdas de bem-estar. Apesar de não ter os dados para medir as perdas de bem-estar com base nos ferimentos, nas mortes, nos danos à propriedade, no desmatamento acelerado e no decréscimo do valor da terra decorrente dos direitos de propriedade incertos, parece haver ganhos importantes a partir do redesenho das políticas de reforma agrária para interromper o ciclo vicioso da invasão e expulsão $\left(2000\right.$, pp. 36-37) ${ }^{56}$.
\end{abstract}

Nesse mesmo sentido, reconheceu a exposição de motivos da Medida Provisória $\mathrm{n}^{\mathrm{o}}$ 458, de 2009, que "desde os anos oitenta as ações de destinação de terras pelo governo federal na Amazônia Legal foram interrompidas, intensificando um ambiente de instabilidade jurídica” (BRASIL, 2009a).

Assim, com vistas a reduzir os conflitos existentes na área e garantir aos posseiros a propriedade da terra em que exercem o cultivo, transferindo-lhes, juntamente com o domínio, responsabilidade socioambiental, foi editada, em 10 de fevereiro de 2009, a Medida Provisória $\mathrm{n}^{\mathrm{o}}$ 458, de 2009 (BRASIL, 2009b), posteriormente convertida na Lei $\mathrm{n}^{\mathbf{0}} 11.952$, de 2009 (BRASIL, 2009d).

Conforme será abordado a seguir, o referido diploma legal, reconhecendo a especificidade da região, marcada pela "instabilidade jurídica, propiciando a grilagem de terras, o acirramento dos conflitos agrários e o desmatamento" (BRASIL, 2009a), estabeleceu dispositivos para simplificar e permitir, de forma ampla, a legitimação da posse no âmbito da Amazônia Legal, regularizando as ocupações incidentes em terras públicas federais, desde que observados determinados requisitos.

\footnotetext{
${ }^{56}$ Tradução livre de: "As illustrated in the Brazilian Amazon, the institutional environment that has emerged results in confusion, conflicting incentives, and welfare losses. Although we do not have the data to measure the losses in welfare from injuries, deaths, property damage, accelerated deforestation, and lower land values due to uncertain property rights, there appear to be important gains from the redesign of land-reform policies that halt the damaging cycle of invasion and eviction" (ALSTON; LIBECAP; MUELLER, 2000, p. 36-37).
} 
Assim, para que se possa iniciar o estudo a respeito da legislação da regularização fundiária, propriamente, faz-se necessário, em primeiro lugar, esclarecer em que consiste a Amazônia Legal e as características que fazem dessa região um contexto tão peculiar.

\subsubsection{A Amazônia Legal}

Em 1953, por meio da Lei $\mathrm{n}^{\mathrm{o}} 1.806$, de 1953 (BRASIL, 1953), que cria a Superintendência do Plano de Valorização Econômica da Amazônia - SPVEA, foram incorporados à Amazônia Brasileira, o Estado do Maranhão (oeste do meridiano $44^{\circ}$ ), o Estado de Goiás (norte do paralelo $13^{\circ}$ de latitude sul, constituindo, atualmente, o Estado de Tocantins) e Mato Grosso (norte do paralelo $16^{\circ}$ latitude Sul).

Art. $2^{\circ}$ A Amazônia brasileira, para efeito de planejamento econômico e execução do Plano definido nesta lei, abrange a região compreendida pelos Estados do Pará e do Amazonas, pelos territórios federais do Acre, Amapá, Guaporé e Rio Branco e ainda, a parte do Estado de Mato Grosso a norte do paralelo de $16^{\circ}$, a do Estado de Goiás a norte do paralelo de $13^{\circ}$ e a do Maranhão a oeste do meridiano de $44^{\circ}$ (BRASIL, 1953).

A partir do referido dispositivo, a Amazônia Brasileira passou a ser chamada de Amazônia Legal, fruto de um conceito político e não apenas geográfico, assinalando sua importância no contexto nacional e considerando a necessidade de planejar e promover o desenvolvimento da região.

Com a edição da Lei $\mathrm{n}^{\circ}$ 5.173, de 1966 (BRASIL, 1966), que extingue a mencionada SPVEA e cria a Superintendência do Desenvolvimento da Amazônia (SUDAM), o conceito de Amazônia Legal é reinventado para fins de planejamento, sendo, ainda, estendido com a previsão contida na Lei Complementar n 31, de 11 de outubro de 1977 (BRASIL, 1977).

Lei $\mathrm{n}^{\circ}$ 5.173, de 1966 Art. $2^{\circ}$ A Amazônia, para os efeitos desta lei, abrange a região compreendida pelos Estados do Acre, Pará e Amazonas, pelos Territórios Federais do Amapá, Roraima e Rondônia, e ainda pelas áreas do Estado de Mato Grosso a norte do paralelo de $16^{\circ}$, do Estado de Goiás a norte do paralelo de $13^{\circ}$ e do Estado do Maranhão a oeste do meridiano de $44^{\circ}$ (BRASIL, 1966).

Lei Complementar $n^{\circ}$ 31, de 1977 Art. 45 - A Amazônia, a que se refere o art. $2^{\circ}$ da Lei $n^{\circ} 5.173$, de 27 de outubro de 1966, compreenderá também toda a área do Estado de Mato Grosso (BRASIL, 1977).

Por sua vez, com a Constituição Federal de 1988, é criado o Estado do Tocantins, e os territórios federais de Roraima e do Amapá são transformados em Estados Federados, 
conforme as previsões contidas nos Atos Disposições Constitucionais Transitórias, artigos $13^{57}$ e $14^{58}$.

Atualmente, nos termos do artigo $2^{\circ}$ da Lei Complementar $n^{\circ}$ 124, de 2007 (BRASIL, 2007a), a Amazônia Legal é uma área que engloba nove estados brasileiros pertencentes à Bacia Amazônica, correspondendo à totalidade dos estados do Acre, Amapá, Amazonas, Mato Grosso, Pará, Rondônia, Roraima e Tocantins, e parte do estado do Maranhão (porção a oeste do Meridiano $44^{\circ}$ ).

Trata-se de uma área de $5.217 .423 \mathrm{~km}^{2}$, que corresponde, aproximadamente, a $61 \%$ do território brasileiro. Sua população, entretanto, equivale a 21.056 .532 habitantes, $12,4 \%$ do total da população do Brasil, o que lhe confere a menor densidade demográfica do país (SUDAM, [2010]).

O baixo índice de povoamento, a grande extensão territorial, a enorme biodiversidade e a existência de inúmeras comunidades tradicionais, como indígenas e quilombolas ${ }^{59}$, revelam, assim, o caráter particular dessa região. Vale ressaltar, em relação à Floresta Amazônica brasileira, o reconhecimento internacional de sua relevância transcendental para as gerações presentes e futuras de todo o planeta, havendo, ainda, expressa alusão no texto constitucional a esse importantíssimo patrimônio nacional (art. $225, \S 4^{\circ}, \mathrm{CF}^{60}$ ). Soma-se a isso a indefinição dos direitos fundiários na Amazônia e, por conseguinte, a grilagem de terra, o acirramento dos conflitos agrários e o avanço do desmatamento, os quais representam grande entrave ao avanço das políticas regionais de desenvolvimento sustentável.

Registra-se que, até 2010, 50\% das terras na região estavam distribuídas em áreas protegidas, assentamentos da reforma agrária e terras militares. O restante se dividia em terras públicas sem destinação ou devolutas, terras públicas ocupadas informalmente e títulos de terras privadas. Importa dizer, segundo noticiado pelo instituto de pesquisa Imazon - Instituto do Homem e Meio Ambiente da Amazônia ${ }^{61}$, que a ausência de dados confiáveis não permitia

\footnotetext{
${ }^{57}$ Art. 13. É criado o Estado do Tocantins, pelo desmembramento da área descrita neste artigo, dando-se sua instalação no quadragésimo sexto dia após a eleição prevista no $\S 3^{\circ}$, mas não antes de $1^{\circ}$ de janeiro de 1989 (BRASIL, 1988).

${ }^{58}$ Art. 14. Os Territórios Federais de Roraima e do Amapá são transformados em Estados Federados, mantidos seus atuais limites geográficos (BRASIL, 1988).

${ }^{59}$ Registra-se que a região é a segunda do país em registros de remanescentes de quilombos, bem como é onde se concentra a maior parte da população indígena, representando 49\% do total (UNICEF, [2010]).

${ }^{60}$ Art. 225, § 4 ${ }^{\circ}$. A Floresta Amazônica brasileira, a Mata Atlântica, a Serra do Mar, o Pantanal Mato-Grossense e a Zona Costeira são patrimônio nacional, e sua utilização far-se-á, na forma da lei, dentro de condições que assegurem a preservação do meio ambiente, inclusive quanto ao uso dos recursos naturais (BRASIL,1988).

${ }^{61} \mathrm{O}$ Imazon é uma associação sem fins lucrativos, cujos objetos sociais são voltados à pesquisa e à promoção do desenvolvimento sustentável na Amazônia, qualificada, juridicamente, como uma Organização da Sociedade Civil de Interesse Público (OSCIP) (IMAZON, [2010]).
} 
afirmar com certeza qual a proporção ocupada por cada uma dessas categorias (BRITO; BARRETO, 2011).

Conforme informações do Governo Federal, entre os anos de 2004 e 2009, foram destinados 81 milhões de hectares de terras federais na Amazônia Legal, constituindo projetos de assentamentos da reforma agrária, unidades de conservação ambiental e terras indígenas. Entretanto, reconheceu-se, oficialmente, em fevereiro de 2009, que a União ainda detinha 67 milhões de hectares não destinados, o que representa, aproximadamente, 13,42\% da área total da região (BRASIL, 2009a).

Desse modo, considerando as peculiaridades da região e com o escopo de alcançar uma solução para os complexos problemas relacionados às ocupações irregulares na Amazônia Legal, foi editada a Medida Provisória no 458, de 2009 (BRASIL, 2009b), posteriormente convertida na Lei $\mathrm{n}^{\circ}$ 11.952, de 2009 (BRASIL, 2009d). A referida lei dispõe, justamente, sobre a regularização fundiária das ocupações incidentes em terras públicas federais, no âmbito da Amazônia Legal. Trata-se, portanto, da criação de um importante instrumento de legitimação de posse na região, que confere a uma situação fática de ocupação o status de direito e, por conseguinte, proteção pelo Estado. O critério de cultivo, ou do aproveitamento racional, como veremos, volta a ser um dos elementos diferenciadores para que a propriedade então pública passe à esfera do domínio privado. Confere-se, assim, importância ao contexto da Amazônia Legal e ao conteúdo da propriedade, reconhecendo-se a presença de valores que lhe são inerentes na ocupação da terra pública, situação essa, até então, juridicamente irregular.

Tal como Dagan (2011), entendemos que apenas uma concepção que reconhece a multiplicidade dos valores da propriedade e celebra a pluralidade de suas instituições estará apta a atender as reais necessidades tanto dos indivíduos quanto da sociedade como um todo. Observa-se, nesse sentido, que, conforme será visto no próximo capítulo, a legislação em apreço parece sugerir esse entendimento, de que a propriedade pode assumir nuances diversas em contextos diferentes, revelando a adoção de uma perspectiva institucional mais ampla, o que se ajusta ao pensamento de Dagan (2011) acerca de uma concepção séria e comprometida de propriedade. Desse modo, para que se possa, posteriormente, examinar essa possível aproximação entre a noção proposta por Dagan (2011) e a visão de propriedade adotada pelo diploma legal, passa-se, então, a abordar a Lei no 11.952, de 2009 (BRASIL, 2009d) e a política pública por ela instituída, analisando-se os dispositivos que disciplinam a 
regularização fundiária da ocupações incidentes em terras públicas federais, em área rurais, no âmbito da Amazônia Legal.

\subsubsection{A Lei nº 11.952, de 2009 e a política pública de regularização fundiária na Amazônia Legal}

Conforme destacado, a Lei $\mathrm{n}^{\circ}$ 11.952, de 2009 (BRASIL, 2009d) trata, dentre outras disposições, da regularização fundiária das ocupações incidentes em terras situadas em áreas rurais, pertencentes à União, no âmbito da Amazônia Legal, objeto do presente estudo.

A partir da promulgação da Lei $n^{\circ}$ 11.952, de 2009 (BRASIL, 2009d), regulada, posteriormente, pelo Decreto $\mathrm{n}^{\circ}$ 6.992, de 28 de outubro de 2009 (BRASIL, 2009f), o Governo Federal deu, então, início ao chamado Programa Terra Legal Amazônia. Trata-se de um programa de política pública voltado à regularização fundiária no âmbito da Amazônia Legal, coordenado pelo Ministério do Desenvolvimento Agrário (MDA), por força do artigo 33, do referido diploma legal ${ }^{62}$.

De acordo com sua própria descrição, o programa tem como objetivo entregar títulos de propriedade aos posseiros que, preenchendo determinados requisitos, ocupam terras públicas federais não destinadas, ou seja, que não sejam reservas indígenas, florestas públicas, unidades de conservação, terrenos de marinha ou áreas reservadas à administração militar ${ }^{63}$.

Consignou-se, ainda, que "o objetivo, com a segurança jurídica, é impulsionar a criação e o desenvolvimento de modelos de produção sustentável na Amazônia Legal” (BRASIL, [2010]a). Assim, conforme destacado pela própria Pasta, a intenção do Programa Terra Legal Amazônia é regularizar as ocupações legítimas, priorizando a tutela dos pequenos produtores e das comunidades locais (BRASIL, [2010]a).

\footnotetext{
${ }^{62}$ Art. 33. Ficam transferidas do Incra para o Ministério do Desenvolvimento Agrário, pelo prazo de 5 (cinco) anos renovável por igual período, nos termos de regulamento, em caráter extraordinário, as competências para coordenar, normatizar e supervisionar o processo de regularização fundiária de áreas rurais na Amazônia Legal, expedir os títulos de domínio correspondentes e efetivar a doação prevista no $\S 1^{0}$ do art. 21 , mantendo-se as atribuições do Ministério do Planejamento, Orçamento e Gestão previstas por esta Lei (BRASIL, 2009d).

${ }^{63}$ Art. 4ํㅜ Não serão passíveis de alienação ou concessão de direito real de uso, nos termos desta Lei, as ocupações que recaiam sobre áreas: I - reservadas à administração militar federal e a outras finalidades de utilidade pública ou de interesse social a cargo da União; II - tradicionalmente ocupadas por população indígena; III - de florestas públicas, nos termos da Lei no 11.284, de 2 de março de 2006, de unidades de conservação ou que sejam objeto de processo administrativo voltado à criação de unidades de conservação, conforme regulamento; ou IV - que contenham acessões ou benfeitorias federais. §1o As áreas ocupadas que abranjam parte ou a totalidade de terrenos de marinha, terrenos marginais ou reservados, seus acrescidos ou outras áreas insuscetíveis de alienação nos termos do art. 20 da Constituição Federal, poderão ser regularizadas mediante outorga de título de concessão de direito real de uso. $\S 2^{\underline{\underline{o}}}$ As terras ocupadas por comunidades quilombolas ou tradicionais que façam uso coletivo da área serão regularizadas de acordo com as normas específicas, aplicando-se-lhes, no que couber, os dispositivos desta Lei (BRASIL, 2009d).
} 
Desse modo, a partir da Lei $\mathrm{n}^{\circ}$ 11.952, de 2009, constata-se que, hoje, a Amazônia Legal passa por um dos maiores processos de regularização fundiária das últimas décadas, por meio do referido programa, implementado e acompanhado pelo Ministério do Desenvolvimento Agrário (MDA), com a participação do Instituto Nacional de Colonização e Reforma Agrária (INCRA).

Segundo as informações do Ministério do Desenvolvimento Agrário (MDA), as áreas públicas passíveis de regularização chegam a 67,4 milhões de hectares, distribuídos em 463 municípios nos nove Estados pertencentes à Amazônia Legal. O foco do programa, de acordo com o que estabelece a legislação, é regularizar ocupações legítimas, de até 15 módulos fiscais ou até 1.500 ha (mil e quinhentos hectares), conferindo ao ocupante que comprovar os requisitos legais o título de propriedade do imóvel (BRASIL, 2009g).

A previsão legal implementada pelo programa reconhece, portanto, a importância da propriedade para os ocupantes de terras naquela região, enxergando nessas situações de fato valores relacionados a esse direito e, por conseguinte, a necessidade de que seja conferida a devida tutela estatal. Percebe-se, pois, como já mencionado, a preocupação do ordenamento com o conteúdo da propriedade, ou seja, com os valores que lhe são inerentes, os quais, uma vez reconhecidos em determinadas relações, legitimam a situação de fato e ensejam sua proteção jurídica.

Ao considerar a substância da concepção e assinalar a importância das relações efetivamente existentes, a regularização apresenta-se, ainda, como uma medida de combate à apropriação ilegal e falsificação de títulos de terra (fenômeno conhecido como grilagem), de atribuição de responsabilidade ambiental e de inserção do agricultor familiar no âmbito do interesse público e da tutela estatal. Isso porque o agricultor não apenas tem garantida sua moradia e a terra para exercer seu cultivo, mas passa, após a regularização, a figurar como destinatário de outras políticas públicas, como de assistência técnica e extensão rural, de regularização ambiental da propriedade, de comercialização de seus produtos e, sobretudo, de concessão de crédito rural.

Sem o título de propriedade, o ocupante, que não tem sua situação juridicamente regularizada, não pode se beneficiar de políticas de financiamento como o Programa Nacional de Fortalecimento da Agricultura Familiar (PRONAF) ${ }^{64}$, reconhecido, atualmente, como um dos programas públicos mais importantes para o desenvolvimento do pequeno agricultor.

\footnotetext{
${ }^{64}$ Nesse sentido, observa-se a matéria veiculada no jornal virtual Newsrondonônia, de que a falta do título da terra impediu o acesso ao crédito na região no ano de 2013 (FALTA, 2013).
} 
A respeito do PRONAF, haja vista sua importância no meio rural, fazem-se oportunas algumas considerações, que demonstram que, de fato, o reconhecimento da propriedade a partir da regularização é também um meio para a inclusão social do agricultor, que passa a fazer parte do âmbito de proteção estatal. O PRONAF visa o fortalecimento da agricultura familiar, mediante apoio técnico e financeiro para promover o desenvolvimento rural sustentável. Seu objetivo geral consiste em fortalecer a capacidade produtiva da agricultura familiar, contribuir para a geração de emprego e renda nas áreas rurais e melhorar a qualidade de vida dos agricultores familiares. Reconhece-se, inclusive, sua importância para que o agricultor familiar permaneça no campo e dê continuidade a diferentes culturas, atividade imprescindível para o desenvolvimento do país social e economicamente.

É possível arrolar várias razões pelas quais o fortalecimento da agricultura familiar
contribui para o desenvolvimento do país. Ela pode propiciar a inserção produtiva do
elevado contingente de famílias em situação de pobreza no meio rural, sendo, nesse
aspecto, um meio de torná-las menos dependentes de programas de transferência de
renda. Segundo o Ministério do Desenvolvimento Social, 54\% da População
Economicamente Ativa (PEA) inscrita no Cadastro Unico para Programas Sociais
em outubro de 2008 eram trabalhadores rurais. Ademais, o crescimento da
agricultura familiar tende a gerar o desenvolvimento regional, ajudando a dinamizar
municípios do meio rural caracterizados pelo êxodo de sua população. Além disso, a
agricultura familiar contribui para a segurança alimentar do país. Por sua vez, o
aumento da oferta de alimentos tem efeitos positivos para a estabilidade de preços e
a preservação do salário real (CONTI; ROITMAN, 2011, p. 134).

Sem o reconhecimento da propriedade ${ }^{65}$, portanto, não pode o agricultor familiar figurar como destinatário de outras políticas públicas de incentivo à agricultura e ao desenvolvimento de sua atividade, sendo, por conseguinte, também a inclusão social um valor implícito ao direito de propriedade concedido aos ocupantes de terras públicas federais no âmbito da Amazônia Legal.

Entende-se, assim, que o valor inclusão social integra o equilíbrio de valores expressado pela propriedade resultante da regularização fundiária. Tal como outras formas de propriedade, portanto, essa propriedade específica expressa um equilíbrio próprio de valores humanos, o qual leva em consideração o tipo de relação social existente de fato e o contexto bastante peculiar da Amazônia Legal. Vale mencionar, como já visto, que a heterogeneidade prescrita pelo pluralismo de valores implica, justamente, a ideia de que diferentes valores ou diferentes equilíbrios devem orientar diferentes áreas do direito e da vida. Tipos diferentes de

${ }^{65}$ Ressalta-se, aqui, que o PRONAF exige do agricultor, para o acesso a políticas públicas, a chamada Declaração de Aptidão ao PRONAF (DAP) só emitida com a comprovação de regularidade de sua ocupação. (BANCO CENTRAL DO BRASIL, 2014). 
interação humana exigem, por conseguinte, equilíbrios diversos a respeito dos compromissos normativos gerais, entendimento esse que revela a importância de se conferir um tratamento específico e contextual à propriedade resultante da regularização fundiária na Amazônia Legal (DAGAN, 2011).

A realidade da população, sobretudo dos pequenos agricultores, economicamente fragilizados, que vivem na zona rural no âmbito da Amazônia Legal, reflete a incapacidade de inserção de seus interesses na esfera pública e de organização política. Em geral, o que se constata é a alienação desses trabalhadores quanto a seus direitos fundamentais e a ausência de uma assistência do Poder Público que permita a formação de uma cultura político-cidadã.

Assim, a regularização fundiária das ocupações existentes no âmbito da Amazônia Legal, ao conferir o título de propriedade ao ocupante da terra pública, desempenha um papel fundamental naquela região. Permite o desenvolvimento da Amazônia Legal, com a atribuição de direitos e responsabilidades ao novo proprietário, garantindo, ainda, sua inclusão social a partir do acesso a políticas públicas e à tutela do Estado. A propriedade tutelada por essa política, portanto, muito mais do que o atributo da exclusividade, considerado por autores como Blackstone (2011) como o principal elemento da propriedade, envolve a inclusão do ocupante de terras nas demais políticas públicas do Estado, a responsabilidade socioambiental do novo proprietário e o próprio desenvolvimento econômico e sustentável da região, conforme será posteriormente abordado a partir da análise específica dos requisitos e das condições que se relacionam com essa forma de propriedade.

É possível observar, com essas considerações, que a Lei, ao instituir uma política pública de regularização fundiária na Amazônia Legal, reconhece o papel-chave da propriedade na sociedade e, de certo modo, implementa uma abordagem social e economicamente estratégica ao estabelecer uma forma específica da propriedade submetida a requisitos e a condições determinados. Percebe-se, assim, que o legislador, em convergência com o pensamento de Waldron (2012) e de Dagan (2011), admite, de certo modo, que questões sobre propriedade implicam questões sobre justiça, reconhecendo que "certas instituições da propriedade podem ser melhores do que outras para a justiça"66 (WALDRON, 2012, p. 7).

Nesse sentido, ao evidenciar a importância da regularização na Amazônia Legal e, por conseguinte, da propriedade que se forma a partir desse processo de regularização, entende-se

\footnotetext{
${ }^{66}$ Tradução livre de: "Certain property institutions may be better than others for justice" (WALDRON, 2012, p. 7).
} 
que é possível afirmar que a Lei da regularização fundiária da Amazônia Legal, em consonância com os princípios e valores que inspiram a Constituição Federal de 1988 (BRASIL, 1988), transparece uma visão múltipla da propriedade. Tal constatação, por sua vez, conforme será visto no capítulo seguinte, leva-nos a crer que o legislador aborda uma forma específica do instituto que privilegia o contexto e reconhece, por conseguinte, o direito enquanto fenômeno social.

Assim, entende-se que a visão revelada pela legislação ora analisada aproxima-se da premissa realista sobre a qual Dagan (2011) constrói sua concepção de propriedade, do direito enquanto fenômeno social, uma instituição em movimento. Essa aproximação, entre a visão do legislador e o conceito de propriedade de Dagan (2011), será, por sua vez, objeto de análise do Capítulo 4 do presente estudo. Porém, desde já, recorda-se, a esse respeito, que o direito, segundo a premissa realista, não pode ser encarado como algo acabado, mas em constante aperfeiçoamento, a ser considerado em conjunto com as demais dimensões sociais. Deve-se, pois, nas palavras de Dewey (1941) pensar o direito a partir da condição social na qual ele surge, bem como dos propósitos para os quais foi criado. O direito, assim, não representa apenas um instrumento de intervenção no complexo de outras atividades, mas o próprio processo social, diretamente relacionado às outras dimensões que compõem a sociedade (DEWEY, 1941, p. 117).

Nesse sentido, percebe-se que a Lei $\mathrm{n}^{\mathrm{o}}$ 11.952, de 2009 (BRASIL, 2009d), implementada pelo Programa Terra Legal Amazônia, afasta-se de uma visão reducionista da propriedade, enxergando a multiplicidade do conceito e, como mencionado, a importância do contexto da Amazônia Legal e do papel desempenhado por essa instituição dentro da sociedade. Reconhecer a pluralidade da propriedade de acordo com o contexto em que se insere significa, pois, admitir a heterogeneidade de suas manifestações na vida real, tal como o faz o referido diploma legal, conforme se passa a abordar.

\subsubsection{A Lei ${ }^{\circ} 11.952$, de 2009 e as diferentes instituições da propriedade}

Como mencionado, a Lei $\mathrm{n}^{\mathrm{o}}$ 11.952, de 2009 (BRASIL, 2009d), fruto da conversão da Medida Provisória n 458, de 2009 (BRASIL, 2009b), dispõe, dentre outras providências, sobre a regularização fundiária das ocupações incidentes em terras situadas em áreas rurais, pertencentes à União, no âmbito da Amazônia Legal. 
A Amazônia Legal, como vimos, é uma área que apresenta uma configuração bastante própria, seja pelos conflitos existentes, pela sua imensa biodiversidade, pelas comunidades tradicionais que ali vivem ou pelas diversas formas de intervenções na região, como, por exemplo, políticas de colonização e reforma agrária. Essas especificidades acarretaram, por sua vez, a existência de distintas formas _ ou, utilizando a denominação de Dagan (2011), instituições _ de propriedade, reconhecidas pela Lei ${ }^{\circ} 11.952$, de 2009:

\begin{abstract}
Art. $3^{\circ}$. São passíveis de regularização fundiária nos termos desta Lei as ocupações incidentes em terras: I - discriminadas, arrecadadas e registradas em nome da União com base no art. $1^{\circ}$ do Decreto-Lei $n^{\circ} 1.164$, de $1^{\circ}$ de abril de 1971 ; II - abrangidas pelas exceções dispostas no parágrafo único do art. $1^{\circ}$ do Decreto-Lei $n^{\circ} 2.375$, de 24 de novembro de 1987; III - remanescentes de núcleos de colonização ou de projetos de reforma agrária que tiverem perdido vocação agrícola e se destinem à utilização urbana; IV - devolutas localizadas em faixa de fronteira; ou V - registradas em nome do Instituto Nacional de Colonização e Reforma Agrária - Incra ou por ele administradas. Parágrafo único. Esta lei aplica-se subsidiariamente a outras áreas sob domínio da União, na Amazônia Legal, sem prejuízo da utilização dos instrumentos previstos na legislação patrimonial (BRASIL, 2009d).
\end{abstract}

As cinco figuras de terras públicas previstas no dispositivo acima colacionado cuidam de situações distintas criadas por diversas normas e, vale ressaltar, em contextos políticos pouco semelhantes.

O inciso I refere-se às terras devolutas situadas em faixas de cem quilômetros de largura em cada lado do eixo de determinadas rodovias na região da Amazônia Legal, antes declaradas indispensáveis à segurança e desenvolvimento nacional.

O inciso II refere-se a propriedades bastante específicas, consideradas como indispensáveis à segurança nacional: "I - incluídas, cumulativamente, na Faixa de Fronteiras"; e "II - contidas nos Municípios de Humaitá (AM), São Gabriel da Cachoeira (AM), Caracaraí (RR), Porto Velho (RO), Ji-Paraná (RO), Vilhena (RO), Altamira (PA), Itaituba (PA), Marabá (PA) e Imperatriz (MA)"67.

O inciso III aborda especificamente a regularização fundiária em área urbana e permite a regularização das ocupações em terras remanescentes de núcleos de colonização ou de projetos de reforma agrária que tiverem perdido vocação agrícola e se destinem à utilização urbana. Nessas hipóteses, a regularização submete-se a procedimento diverso daquele previsto para a regularização em área rural, ocorrendo mediante a doação da terra ao Município, que

\footnotetext{
${ }^{67}$ Parágrafo único do art. $1^{\text {o }}$ do Decreto-Lei no 2.375 , de 1987 (BRASIL, 1987).
} 
deve providenciar o ordenamento territorial urbano, com base no plano diretor ou em lei municipal (artigos 21 e 22, Lei no 11.952 , de $2009^{68}$ ).

$\mathrm{O}$ inciso IV permite a regularização fundiária de ocupações incidentes em terras devolutas localizadas em faixa de fronteira. Essa forma de propriedade integra o patrimônio da União e é considerada indispensável à defesa nacional, por situar-se na faixa até $150 \mathrm{~km}$ de largura "ao longo das fronteiras terrestres, considerada fundamental para a defesa do território nacional" $"$ 69.

E, por fim, o inciso $\mathrm{V}$ relaciona as terras que estão registradas em nome do Instituto Nacional de Colonização e Reforma Agrária (INCRA) ou por ele administradas, possibilitando a legitimação de posse das ocupações ali existentes, desde que presentes os requisitos legais.

A partir da redação do artigo $3^{\circ}$ acima colacionado, já é possível perceber que a Lei reconhece a diferença nas estruturas das propriedades ali elencadas, ao tempo em que as reúne em um mesmo dispositivo e permite que sejam transformadas em uma sexta forma _ou instituição_da propriedade: a propriedade fruto da regularização fundiária.

Vislumbra-se, assim, uma abordagem da propriedade a partir de categorias mais estreitas, o que, em consonância à proposição de Dagan (2011), destina-se a melhor representar a realidade e, por conseguinte, atender às necessidades ali existentes. A esse respeito vale destacar que, para uma adequada construção do conceito, é importante que se tenha em mente que, conforme já dito, a propriedade reflete a heterogeneidade de suas manifestações na vida real. Essa heterogeneidade implica, justamente, a necessidade de que sejam enfatizadas, como objeto de análise, categorias mais estreitas do que a propriedade

\footnotetext{
${ }^{68}$ Art. 21. São passíveis de regularização fundiária as ocupações incidentes em terras públicas da União, previstas no art. $3^{\circ}$ desta Lei, situadas em áreas urbanas, de expansão urbana ou de urbanização específica. § 1 o A regularização prevista no caput deste artigo será efetivada mediante doação aos Municípios interessados, para a qual fica o Poder Executivo autorizado, sob a condição de que sejam realizados pelas administrações locais os atos necessários à regularização das áreas ocupadas, nos termos desta Lei. § 20 Nas hipóteses previstas no § $1^{\circ}$ do art. $4^{\circ}$ desta Lei, será aplicada concessão de direito real de uso das terras. Art. 22 . Constitui requisito para que o Município seja beneficiário da doação ou da concessão de direito real de uso previstas no art. 21 desta Lei ordenamento territorial urbano que abranja a área a ser regularizada, observados os elementos exigidos no inciso VII do art. $2^{\circ}$ desta Lei. $\quad \S 1^{\circ}$ Os elementos do ordenamento territorial das áreas urbanas, de expansão urbana ou de urbanização específica constarão no plano diretor, em lei municipal específica para a área ou áreas objeto de regularização ou em outra lei municipal. $\S 2^{\underline{0}}$ Em áreas com ocupações para fins urbanos já consolidadas, nos termos do regulamento, a transferência da União para o Município poderá ser feita independentemente da existência da lei municipal referida no $\S 1^{\circ}$ deste artigo. $\S 3^{\circ}$ Para transferência de áreas de expansão urbana, os municípios deverão apresentar justificativa que demonstre a necessidade da área solicitada, considerando a capacidade de atendimento dos serviços públicos em função do crescimento populacional previsto, o déficit habitacional, a aptidão física para a urbanização e outros aspectos definidos em regulamento (BRASIL, 2009d).

${ }^{69}$ Art. $20, \S 2^{\circ}$. A faixa de até cento e cinquienta quilômetros de largura, ao longo das fronteiras terrestres, designada como faixa de fronteira, é considerada fundamental para defesa do território nacional, e sua ocupação e utilização serão reguladas em lei (BRASIL, 1988).
} 
genericamente considerada, cuja conformação pode corresponder mais adequadamente às características tanto dos recursos quanto das relações humanas envolvidas.

Por sua vez, o artigo $4^{\circ}$, corroborando com essa visão múltipla da propriedade, estabelece quais as terras não são passíveis de regularização ou que recebem um tratamento diverso daquele disposto na Lei. $\mathrm{O}$ dispositivo ressalva direitos relacionados à propriedade estatal e à propriedade coletiva. Na primeira categoria, encontram-se as terras destinadas ao uso militar e as áreas de reserva ambiental; na segunda, as terras tradicionalmente ocupadas por populações indígenas, as terras das comunidades quilombolas e as terras das demais comunidades tradicionais.

Nos termos do referido artigo, proíbe-se a alienação ou a concessão de direito real de uso às ocupações que recaiam sobre as áreas: I - reservadas à administração militar federal e outras finalidades de utilidade pública ou de interesse social a cargo da União; II tradicionalmente ocupadas por população indígena; III - de florestas públicas, nos termos da Lei $\mathrm{n}^{\circ} 11.284$, de 2 de março de 2006, de unidades de conservação ou que sejam objeto de processo administrativo voltado à criação de unidades de conservação, conforme regulamento; ou IV - que contenham acessões ou benfeitorias federais. Quanto às comunidades quilombolas, o parágrafo $2^{\circ}$ do artigo dispõe que as terras por elas ocupadas serão regularizadas de acordo com as normas específicas, aplicando-se, subsidiariamente, os dispositivos da Lei ${ }^{\circ}$ 11.952, de 2009 (BRASIL, 2009d).

Assim, das terras devolutas às terras entregues para a colonização, das florestas públicas às terras ocupadas por comunidades tradicionais, cada um desses modelos possui um regime próprio, definido por normas específicas e, muitas vezes, bastante complexas. Tal como defendido por Dagan (2011), observa-se, aqui, o reconhecimento de que cada forma da propriedade tem como objetivo, no seu próprio modo e com relação a alguma esfera de aplicação prevista, um conjunto de valores humanos que pode ser promovido por suas regras constitutivas específicas.

Desse modo, ao relacionar separadamente cada tipo de propriedade, a Lei $\mathrm{n}^{\circ} 11.952$, de 2009 (BRASIL, 2009d), transparece sua visão pluralista, reconhecendo a existência de diferentes estruturas abarcadas pelo conceito de propriedade, ou seja, a existência de formas, ou instituições, da propriedade, com conteúdos diversos, a serem analisados contextualmente. Assim, ao considerar a propriedade a partir de categorias mais estreitas, como mencionado, entende-se que a norma reconhece que tanto a forma quanto a substância da propriedade possuem grande importância para a estruturação da concepção. 
Nesse sentido, recorda-se o pensamento de Dagan (2011), que, em sua concepção realista, assinala que, ao se desenvolver as regras acerca de cada forma da propriedade, devese raciocinar a partir do propósito social daquela instituição específica. O direito, para o realismo jurídico, deve, portanto, ser abordado em consideração aos seus propósitos, por tratar-se, justamente, de um meio para atingir determinados fins. Assim, considerando que os requisitos exigidos pela legislação para que seja possível a regularização caracterizam essa forma de propriedade e sinalizam quais seriam os propósitos e os valores a que devem servir a norma ora analisada, passa-se a tratá-los de maneira mais detalhada a seguir.

\subsubsection{Os requisitos para a regularização fundiária: da situação fática tutelada}

Conforme já exposto, a regra, no ordenamento jurídico brasileiro, é no sentido de que a alienação de bens imóveis da União dependerá de autorização legislativa, avaliação prévia e licitação ${ }^{70}$. A regularização fundiária de ocupações de terras públicas federais em áreas rurais na Amazônia Legal permite, contudo, a alienação do imóvel, de forma gratuita ou onerosa, sem o prévio procedimento licitatório. Trata-se, pois, de uma exceção à regra, que privilegia o indivíduo que já ocupa e confere uma utilização apropriada ao imóvel, até então, público.

A implementação da Lei no 11.952, de 2009 (BRASIL, 2009d), ocorre por meio do já mencionado Programa Terra Legal Amazônia, que prevê emitir títulos de terra por meio de cinco fases principais: cadastramento de posses, georreferenciamento, vistoria, titulação e monitoramento pós-titulação ${ }^{71}$.

No que tange ao objeto da regularização fundiária nas áreas rurais, oportuno ressaltar que se trata do chamado "imóvel rural", no qual a atividade econômica é preponderante para sua caracterização, em detrimento de sua localização. Embora a Lei n ${ }^{\circ} 11.952$, de 2009

\footnotetext{
${ }^{70}$ Art. 17, I, da Lei no 8.666, de 1993. A alienação de bens da Administração Pública, subordinada à existência de interesse público devidamente justificado, será precedida de avaliação e obedecerá às seguintes normas: I quando imóveis, dependerá de autorização legislativa para órgãos da administração direta e entidades autárquicas e fundacionais, e, para todos, inclusive as entidades paraestatais, dependerá de avaliação prévia e de licitação na modalidade de concorrência, dispensada esta nos seguintes casos: [...] (BRASIL, 1993b).

${ }^{71}$ Artigo $3^{\circ}$ do Decreto ${ }^{\circ}$ 6.992, de 2009: A regularização fundiária de ocupações incidentes em terras públicas rurais da União ocorrerá de acordo com o seguinte procedimento:I - cadastramento das ocupações e identificação ocupacional por Município ou por gleba, conforme procedimento a ser definido pelo Ministério do Desenvolvimento Agrário; II - elaboração de memorial descritivo dos perímetros das ocupações, com a devida Anotação de Responsabilidade Técnica - ART, por profissional habilitado e credenciado no Instituto Nacional de Colonização e Reforma Agrária - INCRA, contendo as coordenadas dos vértices definidores dos limites do imóvel rural, georreferenciadas ao Sistema Geodésico Brasileiro; e III - formalização de processo administrativo previamente à titulação, instruído com os documentos e peças técnicas descritos nos incisos I e II e aprovado pelo Ministério do Desenvolvimento Agrário, a partir dos critérios previstos na Lei $\mathrm{n}^{\circ} 11.952$, de 2009 , e nas demais normas aplicáveis a cada caso (BRASIL, 2009f).
} 
(BRASIL, 2009c), não preveja essa definição, tanto o Estatuto da Terra (Lei $n^{\circ} 4.504$, de $1964^{72}$ ), quanto a Lei $n^{\circ} 8.629$, de $1993^{73}$ (BRASIL, 1993a), que regulamenta os dispositivos constitucionais sobre a reforma agrária, dispõem nesse sentido.

Assim, permite-se a regularização de ocupações de áreas de até quinze módulos fiscais e não superiores a 1.500 ha (mil e quinhentos hectares), respeitada a fração mínima de parcelamento. Vale dizer que o limite máximo permitido para a regularização, contestável por favorecer não apenas os pequenos agricultores, inova por usar o direito de propriedade como um instrumento para que também os demais proprietários passem a assumir ampla responsabilidade na utilização de terras amazônicas ${ }^{74}$.

Para que seja beneficiado com a regularização, o ocupante do imóvel deve atender a determinados requisitos previstos na Lei, sobretudo no artigo $5^{\circ}$. Assim, os ocupantes, tanto o requerente quanto seu cônjuge ou companheiro, que pretendem ser legitimados como proprietários da terra: (i) devem ser brasileiros, natos ou naturalizados; (ii) não podem ser proprietários de imóvel rural em qualquer parte do território nacional; (iii) devem praticar cultura efetiva; (iv) devem comprovar o exercício de ocupação e exploração direta, mansa e pacífica, por si ou seus antecessores, anterior a $1^{\circ}$ de dezembro de 2004; e (v) não podem ter sido beneficiados por programa de reforma agrária ou regularização fundiária de área rural, ressalvadas as situações admitidas pelo Ministério do Desenvolvimento Agrário (MDA).

A cultura efetiva encontra definição no artigo $2^{\circ}, V$, da Lei, que dispõe tratar-se da “exploração agropecuária, agroindustrial, extrativa, florestal, pesqueira ou outra atividade similar, mantida no imóvel e com o objetivo de subsistência dos ocupantes, por meio da produção e da geração de renda" (BRASIL, 2009d). Cuida-se, pois, de uma concepção bastante aberta, comportando um rol meramente exemplificativo das atividades que podem ser consideradas como cultura efetiva. Observa-se, assim, que é conferida ampla liberdade para que, na prática, se afira se esse requisito da cultura efetiva está ou não presente.

Ao privilegiar o cultivo, permite-se, portanto, a democratização da propriedade nas terras amazônicas, servindo essa, em consonância com o que defende Dagan (2011), à

\footnotetext{
${ }^{72} \mathrm{O}$ Estatuto da Terra define o imóvel rural em seu artigo $4^{\circ}$, I: “'Imóvel Rural', o prédio rústico, a área contínua qualquer que seja a sua localização que se destina à exploração extrativa agrícola, pecuária ou agroindustrial, quer através de planos públicos de valorização, quer através da iniciativa privada" (BRASIL, 1964).

${ }^{73}$ A Lei $\mathrm{n}^{\circ}$ 8.629, de 1993, estabelece, em seu art. 4, I: "Imóvel Rural - o prédio rústico de área contínua, qualquer que seja a sua localização, que se destine ou possa se destinar à exploração agrícola, pecuária, extrativa vegetal, florestal ou agro-industrial" (BRASIL, 1993a).

${ }^{74}$ A respeito do limite máximo permitido para a área a ser regularizada, vale dizer que essa disposição foi objeto de inúmeras manifestações contrárias, que chegaram a denominar a Medida Provisória n ${ }^{\circ} 458$, de 2009, de "MP da Grilagem" (SOB PROTESTO, 2008).
} 
realidade daquele contexto e a valores individuais e sociais que lhe são inerentes. As exigências da cultura efetiva, da morada habitual e da posse aliada ao trabalho revelam a preocupação do legislador com o conteúdo das relações ali presentes, privilegiando quem, de fato, habita e produz na terra. Nesse sentido, verificado o devido aproveitamento da área, garante-se ao agricultor e à sua família, a partir da regularização, não apenas autonomia para promoverem seu autossustento, mas, como vimos, também a sua inclusão social, a partir da possibilidade de virem a ser destinatários de demais políticas públicas ${ }^{75}$. Por conseguinte, a propriedade resultante da regularização revela, a partir desse requisito, a preocupação da norma com o conteúdo dessa forma especifica de propriedade, que tutela valores, portanto, tanto ligados à autonomia e ao desenvolvimento do próprio indivíduo, quanto à comunidade $\mathrm{e}$ ao desenvolvimento _ sustentável _ da região amazônica, exigindo que seja conferida uma destinação adequada ao imóvel, que, vale dizer, não fora efetivada pelo até então proprietário, o Poder Público.

Também entre os requisitos subjetivos para a regularização, não pode o ocupante, seu cônjuge ou companheiro exercer cargo ou emprego público no Incra, no Ministério do Desenvolvimento Agrário (MDA), na Secretaria do Patrimônio da União do Ministério do Planejamento, Orçamento e Gestão (MPOG) ou nos órgãos estaduais de terras. Nos casos em que o ocupante, seu cônjuge ou companheiro exerçam outros cargos ou empregos públicos que não os mencionados deverão ser observados requisitos específicos previstos no artigo $3^{\circ}$, incisos II, III e IV, da Lei $\mathrm{n}^{\circ}$ 11.326, de 24 de julho de 2006 (BRASIL, 2006b). Assim, para que seja possível a regularização nessas hipóteses, além dos requisitos gerais, os ocupantes deverão comprovar que utilizam predominantemente mão-de-obra própria da família nas atividades econômicas do seu estabelecimento ou do seu empreendimento; tenham percentual mínimo da renda familiar originada de atividades econômicas de seu estabelecimento ou empreendimento, na forma definida pelo Poder Executivo; e dirijam seu estabelecimento ou empreendimento com sua família.

Quanto à comprovação dos requisitos, vale ressaltar que, nos termos do art. 13, da Lei n ${ }^{\circ}$ 11.952, de 2009 (BRASIL, 2009d), para áreas de até quatro módulos fiscais, estes serão verificados por meio de declaração do ocupante, sujeita à responsabilização nas esferas penal, administrativa e civil, estando dispensada a vistoria prévia. Já para áreas superiores a quatro e até quinze módulos fiscais, não superiores a mil e quinhentos hectares, além das declarações, é

\footnotetext{
${ }^{75}$ Recorda-se aqui o Programa Nacional de Fortalecimento da Agricultura Familiar - PRONAF, mencionado no item antecedente.
} 
obrigatória a vistoria prévia no local por profissional regularmente habilitado do Poder Executivo Federal ou por outro profissional habilitado em razão de convênio, com a elaboração de laudo em que seja devidamente atestado o cumprimento dos requisitos, verificando-se, sobretudo, a prática da cultura efetiva no local ${ }^{76}$.

Nos termos da Lei, disposição essa, como se verá, bastante questionável, a vistoria é, portanto, exigida apenas para imóveis objetos de regularização com áreas superiores a quatro módulos fiscais. Por sua vez, o art. 5º do Decreto n 6.992, de 2009 (BRASIL, 2009f), traz exceções à regra mencionada, estabelecendo que será obrigatória a vistoria prévia à regularização também dos imóveis com área de até quatro módulos fiscais nos casos em que:

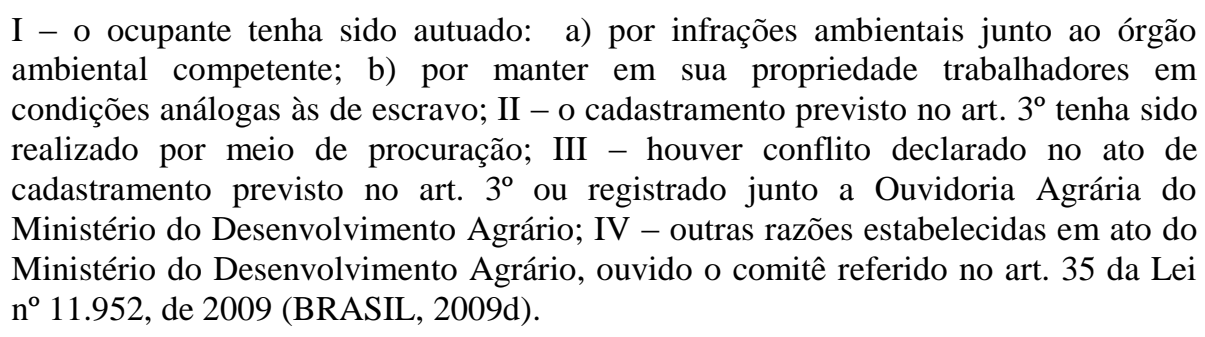

Assim, uma vez preenchidos os requisitos, as áreas serão regularizadas pelo Ministério do Desenvolvimento Agrário (MDA) ou pelo Ministério do Planejamento, Orçamento e Gestão (MPOG), nesse último caso se se tratar de "terras ocupadas que abranjam parte ou a totalidade de terrenos de marinha, terrenos marginais ou reservados, seus acrescidos ou outras áreas insuscetíveis de alienação nos termos do art. 20 da Constituição Federal",77, os quais serão regularizados mediante a concessão de direito real de uso e não, exatamente, do título de propriedade.

Percebe-se, mais uma vez, a partir dos dispositivos colacionados, a importância conferida pela Lei ao conteúdo da relação a ser tutelada, estabelecendo, inclusive, instrumentos, como a vistoria prévia, para que haja a fiscalização a respeito do cumprimento dos requisitos, sobretudo quanto ao cultivo da terra. Conforme será abordado no capítulo seguinte, apesar da questionável dispensa da vistoria prévia referente a imóveis com dimensões inferiores ou equivalentes a quatro módulos fiscais, é possível observar uma aproximação do direito à realidade local, buscando o legislador promover uma organização na

\footnotetext{
${ }^{76}$ Assinala-se que a Portaria no 23, do Ministério do Desenvolvimento Agrário, de 30 de abril de 2010, dispõe sobre os procedimentos para a regularização fundiária de ocupações incidentes em terras situadas nas áreas rurais no âmbito da Amazônia Legal e disciplina a forma de comprovação dos requisitos, para que o ocupante demonstre o preenchimento dos requisitos estabelecidos pela legislação (BRASIL, 2010b).

${ }^{77}$ Art. $4^{\circ}, \S 1^{\circ}$ da Lei $n^{\circ} 11.952$, de 2009 (BRASIL, 2009d).
} 
distribuição de terras e evitando, em certa medida, o risco de que sejam favorecidos meros especuladores e grileiros, o que agravaria os conflitos fundiários, bem como prejudicaria não só os verdadeiros agricultores, como o próprio desenvolvimento da região.

Embora abarque agricultores não considerados como de pequeno porte, alcançando imóveis de até 1.500 ha (mil e quinhentos hectares), a legislação procura favorecer os pequenos agricultores ao estabelecer que a regularização de áreas até um módulo fiscal ocorrerá mediante a alienação gratuita do imóvel ${ }^{78}$. Por sua vez, nos termos do artigo 12 do diploma legal em estudo, nas ocupações de áreas acima de um módulo fiscal, dentro do limite da regularização (até quinze módulos fiscais ou 1.500 ha (mil e quinhentos hectares)), "a alienação e, no caso previsto no $\S^{\circ}$ do art. $6^{\circ}$ desta Lei, a concessão do direito real de uso darse-ão de forma onerosa, dispensada a licitação" (BRASIL, 2009d).

Nesse ponto, ainda demonstrando certa preocupação com os pequenos agricultores, assinala-se a previsão do artigo $12, \S 4^{\circ}$, no sentido de que "o ocupante de área até 4 (quatro) módulos fiscais terá direito aos benefícios do Programa Nossa Terra-Nossa Escola",79 . O referido programa, como forma de estimular a educação na área rural e, por conseguinte, a integração social da família que exerce o cultivo, prevê incentivo financeiro, sob a forma de redução de $50 \%$ do valor da parcela do imóvel alienado, às famílias dos trabalhadores rurais que mantenham todos os seus filhos com idade entre sete e quatorze anos na escola ${ }^{80}$.

Como será visto posteriormente, ao buscar dar prioridade aos pequenos agricultores, é possível perceber, entre os propósitos da norma que rege a matéria, a preocupação com a realidade amazônica e, de certa forma, com a distribuição de riqueza e a inclusão, revelando o reconhecimento de que esses valores sociais são inerentes à propriedade fruto desse tipo de regularização. Como mencionado, a realidade dos pequenos agricultores, economicamente fragilizados, que vivem na zona rural no âmbito da Amazônia Legal, é, sobretudo, de incapacidade de inserção de seus interesses na esfera pública e de ausência de organização política, evidenciando a necessidade de que haja, de fato, uma tutela estatal adequada e efetiva, conferindo-lhes reais oportunidades de subsistência e desenvolvimento.

De acordo com as regras estabelecidas para a regularização, tanto na hipótese de alienação gratuita como na de alienação onerosa, permite-se que a Administração dispense o

\footnotetext{
${ }^{78}$ Art. 11. Na ocupação de área contínua de até 1 (um) módulo fiscal, a alienação e, no caso previsto no $§ 4^{\mathrm{o}}$ do art. $6^{\circ}$ desta Lei, a concessão de direito real de uso dar-se-ão de forma gratuita, dispensada a licitação, ressalvado o disposto no art. $7^{\mathrm{o}}$ desta Lei (BRASIL, 2009d).

${ }^{79}$ Art. $12, \S 4^{\circ}$ da Lei $\mathrm{n}^{\circ} 11.952$, de 2009 (BRASIL, 2009d).

${ }^{80}$ Art. 5º $^{\circ}$ Medida Provisória no 2.183-56, de 2001 (BRASIL, 2001).
} 
procedimento licitatório. A referida dispensa, por sua vez, corrobora a ideia de que a regularização fundiária na Amazônia Legal pretende legitimar situações de fato, como um instrumento a serviço da realidade local, na tentativa de que aos agricultores que já habitam e promovem o adequado cultivo das terras da região sejam garantidos todos os valores relacionados à propriedade, como autonomia, liberdade, igualdade, inclusão e responsabilidade social.

Em relação a imóveis acima de 1.500 ha (mil e quinhentos hectares), vale ressaltar que, de acordo com os termos da Lei em estudo, os ocupantes poderão regularizar apenas o limite previsto na norma. Assim, a regularização de áreas que ultrapassam 1.500 ha (mil e quinhentos hectares) só poderá ocorrer mediante processo licitatório ${ }^{81}$. Para áreas acima de 2.500 ha (dois mil e quinhentos hectares), continua prevalecendo a exigência constitucional de autorização prévia do Congresso Nacional, a teor do disposto no art. 49, XVII da Constituição Federal de 1988 (BRASIL, 1988).

Como se vê, é possível vislumbrar, a partir dos requisitos estabelecidos para a regularização, que a Lei enxerga a importância do papel que a propriedade desempenha na sociedade e a necessidade de uma análise contextual e normativa a respeito das diferentes formas do instituto. Entende-se, portanto, que a norma reconhece que a propriedade é um conceito jurídico de extrema relevância para a garantia de valores individuais, mas, ao mesmo tempo, um instrumento na busca de outros objetivos igualmente valiosos, como justiça distributiva e responsabilidade social. Como será abordado no próximo capítulo, vislumbra-se que a norma ora analisada, convergindo com a visão proposta por Dagan (2011), disciplina uma forma específica da propriedade, transparecendo a compreensão de que a propriedade somente é capaz de atender ao pluralismo de valores e à individualidade na multiplicidade, se, de fato, facilitar as diversas formas de interação humana nos mais variados contextos, reconhecendo, ainda, o direito como um fenômeno social.

Além dos requisitos estabelecidos para que seja possível o reconhecimento da propriedade a partir da regularização fundiária, a Lei prevê condições para que esse direito permaneça nas mãos do novo proprietário. Conforme se passa a expor, entende-se que esses

\footnotetext{
81 A Lei no 8.666, de 1993, em seu art. 17, I, “i” prevê o seguinte: “Art. 17. A alienação de bens da Administração Pública, subordinada à existência de interesse público devidamente justificado, será precedida de avaliação e obedecerá às seguintes normas: I - quando imóveis, dependerá de autorização legislativa para órgãos da administração direta e entidades autárquicas e fundacionais, e, para todos, inclusive as entidades paraestatais, dependerá de avaliação prévia e de licitação na modalidade de concorrência, dispensada esta nos seguintes casos: (...) i) alienação e concessão de direito real de uso, gratuita ou onerosa, de terras públicas rurais da União na Amazônia Legal onde incidam ocupações até o limite de 15 (quinze) módulos fiscais ou 1.500ha (mil e quinhentos hectares), para fins de regularização fundiária, atendidos os requisitos legais" (BRASIL, 1993b).
} 
condicionamentos também dão forma a esse tipo determinado de propriedade, corroborando com a ideia de que se trata de uma instituição específica, contextualizada às peculiaridades da Amazônia Legal.

3.2.5 A concessão do título de domínio: das condições para a manutenção da propriedade

Por sua vez, uma vez realizado o procedimento de regularização, com o cadastramento, o georreferenciamento da área, a comprovação do preenchimento dos requisitos e a vistoria, nas hipóteses em que a Lei a exige, é expedido o que denomina de título de domínio, conferindo a propriedade do imóvel ao ocupante. Vale ressaltar que, na ocupação de área contínua de até um módulo fiscal, o registro será realizado de ofício pelo Registro de Imóveis competente, independentemente de custas e emolumentos ${ }^{82}$.

Nos termos do art. 15, da Lei de Regularização, o referido título é expedido sob condição resolutiva pelo prazo de dez anos ${ }^{83}$, período em que o agora proprietário deverá comprovar: (i) o aproveitamento racional e adequado da área; (ii) a averbação da reserva legal, incluída a possibilidade de compensação na forma da legislação ambiental; (iii) a identificação das áreas de preservação permanente e, quando couber, o compromisso para sua recuperação na forma da legislação vigente; (iv) a observância das disposições que regulam as relações de trabalho; e (v) as condições e forma de pagamento.

Ademais das condições destacadas, por força de disposição legal, o desmatamento que vier a ser considerado irregular em áreas de preservação permanente ou de reserva legal, durante os dez anos assinalados para a vigência das cláusulas resolutivas, implica a rescisão do título de domínio com a consequente reversão da área em favor da União.

A legislação restringe, também, o direito de alienação do proprietário, estabelecendo para aqueles cuja regularização se deu em área de até quatro módulos fiscais o prazo de dez anos para que seja possível a transferência do bem ${ }^{84}$. Para os títulos referentes a áreas superiores a quatro módulos fiscais, o prazo para que se permita a transferência é de três anos,

\footnotetext{
${ }^{82}$ Artigo 11, parágrafo único. O registro decorrente da alienação ou concessão de direito real de uso de que trata este artigo será realizado de ofício pelo Registro de Imóveis competente, independentemente de custas e emolumentos (BRASIL, 2009d).

${ }^{83}$ De acordo com o $\S 1^{\circ}$ do art. 15 , "na hipótese de pagamento por prazo superior a 10 (dez) anos, a eficácia da cláusula resolutiva prevista no inciso V do caput deste artigo, estender-se-á até a integral quitação" (BRASIL, 2009d).

${ }^{84}$ Art. $15, \S 3^{\circ}$. Os títulos referentes às áreas de até 4 (quatro) módulos fiscais serão intransferíveis e inegociáveis por ato inter vivos pelo prazo previsto no caput (BRASIL, 2009d).
} 
“desde que o beneficiário originário esteja cumprindo as cláusulas resolutivas" ${ }^{\text {" }}$. Exige-se, ainda, que o terceiro adquirente cumpra os requisitos previstos em regulamento. Nesses casos, a transferência do título, após a carência de três anos, será efetivada somente mediante a anuência dos órgãos expedidores.

É possível observar, a partir das características acima relacionadas, que a propriedade resultante da regularização fundiária das ocupações em áreas rurais em terras da União, no âmbito da Amazônia Legal, submete-se a um regramento específico, em que há uma série de condicionamentos, atribuindo-se não apenas direitos, mas, em grande parte, responsabilidades ao novo proprietário. Como visto, deve ele atender às cláusulas estabelecidas no título durante o prazo determinado, caso contrário, perde sua propriedade e o bem retorna ao patrimônio da União.

A propriedade proveniente da regularização, portanto, além de exigir requisitos específicos, que revelam um reconhecimento quanto à importância do conteúdo das relações existentes de fato, submete-se, ainda, a condicionamentos, transparecendo a preocupação da norma com o contexto da Amazônia Legal, juntamente com uma visão do direito enquanto fenômeno social. Assim, conforme será visto mais detalhadamente no capítulo seguinte, entende-se que, por possuir características bastante próprias, que refletem as peculiaridades da região amazônica e os valores a que a propriedade deve servir naquele contexto, a propriedade resultante da regularização fundiária em áreas rurais da Amazônia Legal constitui uma instituição específica da propriedade.

Nesse sentido, considerando que a configuração da propriedade a partir de instituições possibilita que se efetive a proteção de várias categorias de interação humana, observa-se que a Lei em estudo aproxima-se da promoção de importantes valores humanos, permitindo, ao mesmo tempo, estabilidade e previsibilidade. É possível perceber que a norma opta por uma abordagem a partir de categorias mais estreitas, seguindo, por conseguinte, o compromisso de que o direito deve servir à vida, bem como permitindo aos atores jurídicos uma proximidade com a realidade existente naquele contexto específico, de sorte a conformar a lei e sua aplicação às reais necessidades humanas. Reconhece-se a importância dessa abordagem e dessa aproximação, justamente, para que o direito não se restrinja a, nas palavras de Dewey (1941), “pedaços de papéis ou vozes no ar” (DEWEY, 1941, p. 118).

\footnotetext{
${ }^{85}$ Art. $15, \S 4^{\circ}$. Desde que o beneficiário originário esteja cumprindo as cláusulas resolutivas, decorridos 3 (três) anos da titulação, poderão ser transferidos títulos referentes a áreas superiores a 4 (quatro) módulos fiscais, se a transferência for a terceiro que preencha os requisitos previstos em regulamento (BRASIL, 2009d).
} 
A esse respeito, recorda-se, novamente, o pensamento de Dagan (2011) acerca da importância de se raciocinar as formas da propriedade a partir do propósito social daquela instituição específica. Uma vez que a propriedade _ assim como o direito, em geral _ consiste em um meio para se alcançar determinados fins, como um mecanismo coercitivo apoiado pelo poder do Estado, suas prescrições devem ser justificadas em termos de promover valores humanos.

Assim, com base nessa premissa orientadora da construção de um conceito contemporâneo de propriedade, no que tange ao ordenamento jurídico brasileiro, é possível identificar que a Lei da Regularização procurou alcançar, entre seus objetivos principais, a promoção da inclusão e da justiça social, conferindo amparo a posseiros de boa-fé que retiram da terra seu sustento; e conferir responsabilidade socioambiental, aperfeiçoando o controle e a fiscalização do desmatamento e permitindo uma melhor definição dos responsáveis pelos prejuízos eventualmente causados ao meio ambiente nas áreas regularizadas. A garantia e a efetivação desses valores inspiram, por conseguinte, os propósitos normativos que se relacionam com a regularização fundiária das terras públicas federais na Amazônia Legal.

Diante dessas considerações, passa-se, assim, no último capítulo, a abordar a já sinalizada convergência entre a visão realista da propriedade e a Lei $\mathrm{n}^{\mathrm{o}} 11.952$, de 2009 (BRASIL, 2009d), o que se reflete nos propósitos normativos subjacentes ao diploma legal. Como mencionado e veremos de forma mais detalhada a seguir, estudar os propósitos da norma revela-se extremamente importante para a orientação de decisões racionais a respeito da matéria, bem como na busca por um constante aperfeiçoamento do direito de propriedade resultante da regularização fundiária, permitindo que seja alcançada, de forma efetiva, a tutela dos valores a ela inerentes. 


\section{OS PROPÓSITOS NORMATIVOS DA LEI $\mathbf{N}^{\circ}$ 11.952, DE 2009 E RECONHECIMENTO DE UMA NOVA INSTITUIÇÃO DA PROPRIEDADE: A PROPRIEDADE AMAZÔNICA}

\subsection{Os propósitos normativos subjacentes à regularização fundiária na Amazônia Legal}

Como visto ao longo dos capítulos anteriores, entende-se que, atualmente, não há espaço para uma visão reducionista da propriedade, sendo essa denominação a roupagem de um complexo bastante distinto e independente de relações, no qual estão presentes inúmeros valores, equilibrados de formas diversas e conectados ao contexto em que estão inseridos.

A visão realista, que inspira a concepção de propriedade proposta por Dagan (2011), parte da premissa do direito enquanto uma instituição em movimento, um fenômeno social, que, portanto, não pode ser encarado como algo acabado, mas em constante aperfeiçoamento. Conforme visto, como fenômeno social, o direito não pode, ainda, ser tratado como se fosse algo separado das demais dimensões da sociedade, devendo ser discutido em termos da condição social na qual ele surge e dos propósitos para os quais foi criado (DEWEY, 1941, p. 117).

A partir dessa visão realista do direito, percebe-se que a análise jurídica precisa tanto de dados empíricos quanto de juízos normativos. O direito, portanto, como algo mutável, não possui um significado totalmente preestabelecido, reconhecendo-se que os tribunais possuem um importante papel na sua criação, ao lhe atribuir significado nos casos concretos. Se a propriedade, como vimos, é entendida como um conjunto de instituições, o apelo a essas formas não pode ser tido como a parte final da análise jurídica. Ao contrário, Dagan (2011) defende que essa abordagem demanda um constante e cauteloso processo de identificação dos valores humanos subjacentes às formas existentes de propriedade e à concepção do regime de governança a fim de promovê-los adequadamente.

Entende-se, nesse sentido, que a aplicação das normas integra a estrutura da própria concepção de direito, tratando-se de uma parte necessária do termo para que não se trate apenas de "pedaços de papéis ou vozes no ar" (DEWEY, 1941, p. 118). "Um determinado dispositivo jurídico consiste no que ele faz, e o que ele faz remete ao campo de modificação e/ou manutenção de atividades humanas" ${ }^{\nexists 6}$ (DEWEY, 1941, p. 118).

\footnotetext{
${ }^{86}$ Tradução livre de: "A given legal arrangement is what it does, and what it does lies in the field of modifying and/or maintaining human activities as going concerns" (DEWEY, 1941, p. 118).
} 
Dewey (1941), portanto, enfatiza a importância das consequências, em função do que se passa socialmente. Segundo o autor, para o constante aprimoramento do direito, é necessário investigar, em termos de contexto de situações reais, as consequências das regras jurídicas, das decisões jurídicas propostas e dos atos legislativos (DEWEY, 1941, p. 121).

Por sua vez, nesse ponto, importa assinalar, novamente, que o direito é também lugar da razão, elemento que coloca verdadeiras restrições às escolhas dos tomadores de decisão judicial e, portanto, ao exercício concomitante do poder do Estado (DAGAN, 2011, p. XIX). Conforme já dito, o direito deve servir à vida e só se justifica enquanto facilitar e promover os valores humanos, em sua pluralidade, o que deve ser observado por todos os atores jurídicos.

A heterogeneidade prescrita por esse pluralismo de valores significa, na verdade, que diferentes valores ou diferentes equilíbrios devem orientar as diversas áreas do direito, bem como os diferentes atores jurídicos. Há que se ter em mente, contudo, que essa ideia não pode ser equiparada a um convite à aplicação de preferências subjetivas, ou seja, a teoria da propriedade não deve implicar a problemática abordagem da regra sensitiva do particularismo, que permite que os juízes afastem-se das regras de acordo com o resultado. Não se deve focar, portanto, em ações ou no senso de cada caso, de forma particular, mas, antes, buscar-se uma visão de sentido e razão em algum tipo significativo de situação da vida (LLEWELLYN, 1962, p. 215). Recorda-se, aqui, a interessante observação de Dagan (2011) de que as normas existentes representam um acúmulo de experiência judicial e legislativa digno de respeito, devendo ser o ponto de partida de uma análise normativa. Assim, para uma aplicação adequada do direito, faz-se necessário considerar tanto os valores substanciais, quanto o valor de preservar a integridade da norma, o que deve inspirar, por conseguinte, uma visão voltada ao aperfeiçoamento normativo (DAGAN, 2011, pp. XXIII-XXIV).

Nesse sentido, conforme destaca Dagan (2011), observa-se que uma concepção adequada de propriedade confere importância tanto à forma quanto à substância do conceito. As formas da propriedade, como já mencionado, não podem ser irrefletidamente descartadas, porquanto representam as molduras das interações existentes entre as pessoas. A propriedade, assim, deve ser vista como um conjunto de relações interpessoais, enquadráveis, por sua vez, em formas previamente estabelecidas. Enquanto forma, portanto, corresponde a molduras das interações interpessoais que consolidam as expectativas das pessoas e expressam os ideais normativos do direito para o centro das relações humanas. Enquanto substância, cada instituição da propriedade tem como objetivo, no seu próprio modo e com relação a alguma esfera de aplicação prevista, um conjunto de valores humanos que pode ser promovido por 
suas regras constitutivas. Desse modo, a configuração existente da forma da propriedade deve ser analisada a partir de uma perspectiva normativa e contextual voltada para que cada tipo específico de propriedade, efetivamente, sirva àqueles importantes valores, individuais e sociais, que, por sua vez, inspiraram os propósitos para os quais essa instituição da propriedade fora criada.

Nessa linha de raciocínio, tem-se que juízes e tribunais devem orientar suas decisões também com base nos propósitos das normas, voltando-se, assim, aos valores tutelados pelas formas existentes no ordenamento. Entende-se, pois, que cabe aos julgadores, empregando a razão em suas escolhas, guiar-se não apenas pelas regras expressamente estabelecidas, mas, ainda, pelos propósitos subjacentes às previsões legislativas, de modo a proporcionar uma efetiva proteção _ e fruição _ dos direitos presentes em cada caso.

Assim, a análise da regularização fundiária das ocupações incidentes em terras públicas federais, nas áreas rurais, no âmbito da Amazônia Legal deve levar em consideração também os propósitos que inspiraram a legislação. Busca-se, então, a partir de uma análise normativa e contextual, revelar quais seriam os propósitos subjacentes à normatização dessa modalidade de regularização fundiária e, por conseguinte, os valores humanos a que serve a propriedade fruto desse processo. Como dito, esse estudo encontra sua relevância na medida em que possa orientar as ações dos atores jurídicos, sobretudo magistrados, a respeito da matéria, permitindo, assim, uma previsibilidade quanto às suas decisões acerca da regularização fundiária nas áreas rurais da Amazônia Legal.

Em primeiro lugar, diante das considerações já levantadas no presente estudo, sobretudo no que tange aos requisitos e às condições relacionados à propriedade fruto da regularização fundiária na região amazônica, constata-se um ponto bastante importante a respeito da edição da Medida Provisória n ${ }^{\circ} 458$, de 2009 (BRASIL, 2009b), posteriormente convertida na Lei n 11.952, de 2009 (BRASIL, 2009d): o legislador reconheceu a pluralidade da concepção de propriedade, admitindo conteúdos diversos sob o amparo do mesmo "invólucro aberto e disponível que convencionalmente identificamos como propriedade” (GROSSI, 2006, p. 5).

Enxerga-se, assim, a adoção pela legislação de uma visão múltipla da propriedade, o que, por sua vez, revela-se como o resultado, nas palavras de Grossi (2006), de uma instância relativizadora, "recuperação ao devir das coisas mortais daquilo que uma refinada ideologia havia projetado sobre o pináculo mais alto de um templo sacro [a propriedade moderna]" (GROSSI, 2006, p. 6). Essa visão múltipla reflete, como já abordado, a heterogeneidade das manifestações da propriedade da vida real, o que implica, por sua vez, que a análise acerca da 
concepção ocorra com base em categorias mais estreitas, tal como o faz a legislação em estudo. Essa abordagem, portanto, corresponde, de maneira mais adequada, às características relevantes dos recursos, ao contexto em que estão inseridos e às relações humanas envolvidas.

A esse respeito, como visto anteriormente, já nos artigos $3^{\circ}$ e $4^{\circ}$ da Lei de Regularização (BRASIL, 2009d), que estabelecem cada tipo de propriedade de forma separada, subdividindo-as entre categorias que podem e que não podem se submeter à regularização, percebe-se a diferenciação, pelo legislador, dos conteúdos das propriedades, fazendo transparecer sua concepção pluralista, distante, portanto, da noção genérica e abstrata de propriedade. Observa-se, assim, desde os seus primeiros artigos, que a Lei reconheceu que a propriedade deve ser abordada a partir de categorias mais estreitas, admitindo, por conseguinte, que o instituto pode assumir formas diversas, com regramentos específicos, de acordo com o contexto e com as relações interpessoais que representa.

Por sua vez, ao estabelecer requisitos e condições determinados para que seja possível a regularização fundiária na Amazônia Legal, a Lei confere à propriedade fruto desse processo um tratamento específico, confirmando a adoção de uma visão contextualizada da propriedade, que, uma vez inserida no cenário rural amazônico, reflete uma forma peculiar de realidade fundiária, com características diversas das demais regiões do Brasil.

Nesse sentido, recorda-se que, para que seja beneficiado com a regularização, o ocupante do imóvel deve atender aos requisitos previstos no artigo $5^{\circ}$ da Lei: (i) ser brasileiro, nato ou naturalizado; (ii) não ser proprietário de imóvel rural em qualquer parte do território nacional; (iii) praticar cultura efetiva; (iv) comprovar o exercício de ocupação e exploração direta, mansa e pacífica, por si ou seus antecessores, anterior a $1^{\circ}$ de dezembro de 2004; e (v) não ter sido beneficiado por programa de reforma agrária ou regularização fundiária de área rural, ressalvadas as situações admitidas pelo Ministério do Desenvolvimento Agrário (BRASIL, 2009d). Por sua vez, para as ocupações com áreas contínuas de até um módulo fiscal, a alienação ocorrerá gratuitamente, enquanto para aquelas superiores a um módulo e dentro do limite permitido (até 15 (quinze) módulos fiscais, desde que inferior a 1.500ha (mil e quinhentos hectares)), a alienação será feita de forma onerosa, dispensada a licitação em ambos os casos. Lembra-se, nesse ponto, que a avaliação do imóvel, nos casos de alienação onerosa, terá como base o valor mínimo estabelecido em planilha referencial de preços, sobre o qual incidirão índices que considerem os critérios de ancianidade da ocupação, especificidades de cada região em que se situar a respectiva ocupação e dimensão da área (BRASIL, 2009d). 
Assim, ao exigir a cultura efetiva, a morada habitual, a posse aliada ao trabalho, proibindo, ainda, que o ocupante seja proprietário de outro imóvel, o legislador revela sua preocupação com o conteúdo das relações ali presentes. Privilegia, pois, quem não é proprietário de outros imóveis no território nacional, em atenção à distribuição de riqueza, e quem, de fato, promove o cultivo da terra e, consequentemente, contribui para o desenvolvimento, sustentável e racional, daquela região. Verificado o devido aproveitamento da área, garante-se ao agricultor e à sua família, a partir da regularização, não apenas autonomia para promoverem seu autossustento, mas, como já abordado, sua inclusão social, a partir da possibilidade de virem a ser destinatários de demais políticas públicas, como o mencionado PRONAF, importante programa de financiamento para o pequeno agricultor, que permite o desenvolvimento econômico do indivíduo e, por conseguinte, da região.

Observa-se, assim, que a intenção de conferir um tratamento particular à propriedade resultante da regularização e essa visão relativizada do conceito, atribuindo importância à sua substância, evidenciam a relevância, para a regularização fundiária, do contexto da Amazônia Legal e da realidade dos agricultores que cultivam as terras. Enfatizando, pois, os valores presentes nas relações interpessoais existentes de fato, a Lei nos permite perceber uma maior proteção à pequena propriedade, a ser alienada, como ressaltado, de forma gratuita até um módulo fiscal, bem como com condições de pagamento favoráveis quando se tratar de áreas de um a quatro módulos fiscais (artigos 11 e 12 da Lei no 11.952, de 2009 (BRASIL, 2009d)).

A propriedade resultante da regularização revela, portanto, a partir dos requisitos exigidos pela Lei e das disposições destacadas, a preocupação da norma com a tutela de valores tanto ligados à utilidade, à autonomia e ao desenvolvimento do próprio indivíduo, quanto à distribuição de riqueza, à comunidade e ao desenvolvimento sustentável da região amazônica. Converge, assim, conforme já assinalado, com a ideia de propriedade como um conjunto de instituições, em que cada instituição é designada para enquadrar o equilíbrio específico entre os valores relevantes da propriedade que melhor se encaixa ao complexo de características sociais daquele contexto.

Por seu turno, evidenciando que também a organização coletiva e a tutela de comunidades tradicionais encontram-se entre os valores inerentes à propriedade fruto da regularização, inspirando, assim, os propósitos da norma, a Lei impede a legitimação de ocupações sobre terras pertencentes a comunidades indígenas e quilombolas. Referida disposição transparece, portanto, mais uma vez, a preocupação com o contexto amazônico, levando em consideração que a região é a segunda do país em registros de remanescentes de 
quilombos e onde se concentra a maior parte da população indígena ${ }^{87}$. Assim, embora se esteja ainda distante de resolver esses tipos de conflitos naquela região, a Lei transparece a necessidade de que os direitos das comunidades tradicionais sejam priorizados e tutelados de forma adequada e específica, no âmbito da Amazônia Legal. Nesse mesmo sentido, assinalase o teor do artigo $8^{\circ}$, da Lei de Regularização, que estabelece que, em caso de conflito nas regularizações em áreas rurais, a União priorizará a regularização em benefício das comunidades locais, definidas no inciso X do artigo $3^{\circ}$ da Lei no 11.284, de 2006 (BRASIL, 2006a), se o conflito for entre essas comunidades e um particular. Tutelam-se, assim, os direitos das "populações tradicionais e outros grupos humanos, organizados por gerações sucessivas, com estilo de vida relevante à conservação e à utilização sustentável da diversidade biológica" ${ }^{98}$.

Desse modo, percebe-se que, além de priorizar o conteúdo das diversas estruturas das propriedades dentro do contexto em que se inserem, os referidos dispositivos evidenciam a importância da organização coletiva e da tutela de comunidades tradicionais, reconhecendo a incidência desses valores naquele tipo específico de propriedade e a importância das relações _e das expectativas_estabelecidas por grupos sociais.

Do mesmo modo, corroborando com o entendimento de que a Lei $\mathrm{n}^{\circ} 11.952$, de 2009 (BRASIL, 2009d) adotou uma visão contextualizada e relativizada da propriedade, verificamse os termos da Exposição de Motivos da Medida Provisória n 458, de 2009 (BRASIL, 2009a).

Como já destacado, entre os fatores presentes naquela região, que delineiam seus contornos de forma bastante particular, estão a biodiversidade amazônica e os conflitos fundiários de grandes proporções, causados, sobretudo, pela imprecisão acerca do pertencimento das terras. Esse fato, que introduz a mencionada Exposição de Motivos (BRASIL, 2009a), foi, ainda, ratificado pela informação, também presente naquele documento, de que, desde a década de 1980, as ações de destinação de terras pelo Governo Federal na Amazônia Legal foram interrompidas. A falta de políticas públicas, portanto, agravou ainda mais a situação, dada a pressão pela terra e a imprecisão de sua posse, alimentando os conflitos fundiários, além do desmatamento que, em diversas situações, está ligado à tomada de poder sobre determinada terra.

\footnotetext{
${ }^{87}$ Recorda- aqui, conforme destacado na nota de rodapé 59 supra, que a região é a segunda do país em registros de remanescentes de quilombos, bem como é onde se concentra a maior parte da população indígena, representando 49\% do total (UNICEF, [2010]).

${ }^{88}$ Definição trazida pelo inciso X do art. 30 da Lei no 11.284, de 2 de março de 2006 (BRASIL, 2006a).
} 
2. Desde os anos oitenta as ações de destinação de terras pelo governo federal na Amazônia Legal foram interrompidas intensificando um ambiente de instabilidade jurídica, propiciando a grilagem de terras, o acirramento dos conflitos agrários e o avanço do desmatamento (BRASIL, 2009a).

O item terceiro da referida exposição de motivos reconhece, ainda, que "a União detém 67 milhões de hectares não destinados, ou seja, 13,42\% da área total da região”, terras onde seria possível implantar uma política de regularização fundiária, "reduzindo os conflitos e permitindo segurança jurídica, inserção produtiva e acesso às políticas públicas para aqueles que hoje a ocupam" (BRASIL, 2009a).

Como explicitado dentre as razões para a proposição da norma, os requisitos estabelecidos para a regularização das posses demonstram a preocupação com a realidade local e com a necessidade de se evitar "riscos de reconcentração fundiária, de especulação imobiliária e de abertura desordenada da fronteira agrícola" (BRASIL, 2009a), exigindo a ocupação direta, mansa e pacífica anterior a $1^{\circ}$ de dezembro de 2004 e a existência de cultura efetiva na área a ser regularizada.

9. Os títulos resultantes desse processo conterão cláusulas resolutivas com prazo de 10 anos que prevêem entre outras, a inalienabilidade das terras, a utilização adequada dos recursos naturais e preservação do meio ambiente. Com essas medidas entendemos que serão preservados os riscos de reconcentração fundiária, de especulação imobiliária e abertura desordenada da fronteira agrícola, contribuindo para o controle do desmatamento na Amazônia Legal.

10. Com base nos dados do Cadastro existente no INCRA estimamos um público alvo de aproximadamente trezentas mil famílias em todos os Estados da Amazônia Legal que poderão se beneficiar das medidas ora propostas.

11. A urgência da medida justifica-se pela necessidade de superar o obstáculo que ausência de regularidade das ocupações existentes na região representa para o desenvolvimento econômico local e para implementação de políticas de desenvolvimento urbano condizentes com as diretrizes estabelecidas legalmente (BRASIL, 2009a).

Tais passagens constantes da Exposição de Motivos (BRASIL, 2009a), juntamente com os dispositivos legais mencionados, portanto, revelam a preocupação do legislador com o contexto em que aquele tipo de propriedade está inserido, bem como com o conteúdo das relações passíveis de regularização fundiária na Amazônia Legal.

Desse modo, entende-se, conforme já sinalizado, que é possível afirmar que a norma, ao tratar da propriedade, opta por uma abordagem a partir de categorias mais estreitas, o que, como sugere Dagan (2011), segue o compromisso de garantia que o direito sirva à vida, ao tempo em que preserva certa estabilidade e previsibilidade, necessárias ao bom 
desenvolvimento da sociedade. Recorda-se, aqui, a pontuação do autor no sentido de que esse tipo de abordagem permite, inclusive, que os juristas desenvolvam uma distinção necessária para um tratamento de intimidade, mantendo-se perto da real "transação da vida" e amoldando a lei às necessidades humanas ali existentes (DAGAN, 2011, p. XXIII).

Com base na referida abordagem, permite-se, então, que, em determinadas hipóteses, prevaleça a situação de fato consolidada, reconhecendo-se determinados valores inerentes ao direito de propriedade na ocupação do posseiro. Privilegiando o trabalho, a autonomia e a distribuição de riqueza, confere-se, portanto, prioridade à proteção das relações ali presentes. Em outros casos, por sua vez, impede-se a regularização de determinada ocupação, fazendo prevalecer, nessas hipóteses, outros valores, também inerentes à propriedade, como, por exemplo, a proteção ambiental, a defesa do território nacional e a tutela das comunidades tradicionais existentes. Em ambos os casos, vale dizer, verifica-se que a Lei revela uma preocupação com o conteúdo das relações provenientes do vínculo que liga o homem à coisa.

Dessa sorte, a partir da análise da Lei no 11.952, de 2009 (BRASIL, 2009d), é possível perceber que diversas formas de propriedade, ainda hoje, convivem na região amazônica brasileira, sendo que aquela que decorre da regularização pode ser vista também uma forma particular de propriedade, submetendo-se a regramentos próprios e servindo a valores específicos presentes na relação ali existente. A garantia e a efetivação desses valores inspiram, por conseguinte, os propósitos normativos que se relacionam com a regularização fundiária das terras públicas federais na Amazônia Legal.

Diante dessas considerações, entre os propósitos da norma, constatam-se, assim, sobretudo, os de assegurar os direitos das comunidades tradicionais, promover a inclusão e a justiça social, bem como atribuir responsabilidade socioambiental e aperfeiçoar o controle e a fiscalização ambiental na Amazônia, permitindo-se uma melhor definição dos responsáveis pelas lesões ao meio ambiente nas áreas regularizadas. Cabe aos atores do direito, portanto, ao tratar da regularização fundiária na Amazônia Legal, orientar suas decisões com base nesses propósitos, promovendo, concretamente, os valores inerentes à normatização da matéria.

Ademais, ainda em consonância com a visão de propriedade sustentada por Dagan (2011), de inspiração realista, outro ponto chama atenção, nas disposições legais, a respeito dos propósitos da norma incidente na regularização fundiária amazônica. De acordo com a previsão contida no artigo 35 da Lei, a implementação de suas disposições "será avaliada de forma sistemática por comitê instituído especificamente para esse fim, assegurada a 
participação de representantes da sociedade civil organizada que atue na região amazônica $[\ldots]^{, 89}$.

Com base no referido dispositivo foi estabelecido, pelo Decreto de 27 de abril de 2009 (BRASIL, 2009c), o Grupo Executivo Intergovernamental - GEI, “com a finalidade de definir diretrizes e monitorar as ações de regularização fundiária nas terras da União localizadas na Amazônia Legal" (BRASIL, 2009c). Dentre as atribuições do referido Grupo, assinala-se a de aprovar diretrizes e estratégias para a ação governamental, estabelecer metas de regularização, acompanhar a execução das ações e avaliar seus resultados ${ }^{90}$.

Percebe-se, analisando o teor da referida previsão, a preocupação do legislador com as consequências fáticas da norma. Essa visão se coaduna, a nosso ver, com o raciocínio recomendado pela abordagem realista, no sentido de que a análise normativa deve recorrer aos efeitos materiais do direito de propriedade _no caso, da propriedade resultante da regularização fundiária amazônica_ sobre o comportamento das pessoas, analisando seu impacto expressivo e constitutivo, bem como a interdependência desses dois efeitos (DAGAN, 2011, p. 29).

A Lei, pois, considerou a relevância e a necessidade de que suas consequências sejam verificadas empiricamente, permitindo que, a partir da análise de seus resultados, seja aferido se as formas previstas atendem aos valores que se pretende alcançar com a normatização. É possível, assim, detectar, na visão do legislador, uma concepção do direito enquanto fenômeno social, submetido, pois, a uma análise constante voltada ao seu aprimoramento. Desse modo, abre-se espaço para a compreensão de que o direito de propriedade que, assim como o direito em geral, consiste em um mecanismo coercitivo apoiado pelo poder do Estado, deve ser justificado em termos de promoção de valores humanos. Isso porque, como visto, a legislação reconhece e permite a reavaliação daquela forma específica da propriedade quanto à sua efetividade em promover os valores aceitos e, ainda, quanto à manutenção da validade e da conveniência desses valores.

\footnotetext{
${ }^{89}$ Art. 35, Lei n ${ }^{\circ} 11.952$, de 2009. A implementação das disposições desta Lei será avaliada de forma sistemática por comitê instituído especificamente para esse fim, assegurada a participação de representantes da sociedade civil organizada que atue na região amazônica, segundo composição e normas de funcionamento definidas em regulamento (BRASIL, 2009d).

${ }^{90}$ Art. $3^{\circ}$ do Decreto de 27 de abril de 2009. Compete ao Grupo Executivo Intergovernamental: I - aprovar diretrizes e estratégias para a ação governamental relativa à regularização fundiária na Amazônia Legal; II estabelecer metas de regularização fundiária na Amazônia Legal e o cronograma para o seu cumprimento; III promover as articulações necessárias, inclusive com estados e municípios, para a eficaz implementação das ações de que trata o inciso I; IV - coordenar a atuação dos órgãos e entidades envolvidos na implementação das ações de regularização fundiária na Amazônia Legal; V - acompanhar a execução das ações e avaliar os seus resultados; e VI - dirimir os conflitos de interesse entre o Ministérios ou órgãos públicos federais que tenham como objeto áreas ocupadas a serem regularizadas na Amazônia Legal (BRASIL, 2009c).
} 
Portanto, considerando os propósitos da normatização da regularização fundiária, é possível vislumbrar no diploma legal, em convergência com a visão realista aqui abordada, a percepção da propriedade a partir de um espírito que Dagan (2011) traduz como antifundametalista: pluralista e múltiplo, dinâmico e mutável, hipotético e não autoevidente, mais problemático do que determinante (DAGAN, 2011, p. 29).

Logicamente, reconhecemos que a Lei não corresponde à solução de todos os problemas fundiários da Amazônia Legal, estando-se, ainda, muito distante desse ideal. A própria norma apresenta incoerências com os propósitos revelados a partir de uma análise conjunta e contextual. Conforme será visto, os direitos das comunidades tradicionais, a promoção da inclusão, a justiça social, o controle e a fiscalização do desmatamento na Amazônia em determinados momentos não recebem o devido tratamento para que sejam, efetivamente, assegurados.

Ademais, como qualquer objeto regrado pelo direito, é necessário permanente aperfeiçoamento, bem como uma implementação prática efetiva, tanto dos meios para a delimitação das áreas e acesso à política, quanto de uma fiscalização comprometida, honesta e constante. Um primeiro questionamento a respeito da Lei, por exemplo, já começa pelo limite máximo permitido para a regularização, de até 1.500 ha (mil e quinhentos hectares), uma área extremamente extensa. Ainda que a disposição inove por atribuir também aos médios proprietários ampla responsabilidade na utilização de terras amazônicas ${ }^{91}$, na medida em que se constatar eventual prejuízo à população local, ao desenvolvimento sustentável da região ou mesmo um possível favorecimento à grilagem, considerando a dispensa de licitação, esse dispositivo deverá ser objeto de alteração. Nesse sentido, vale dizer que, conforme sugere a abordagem realista da propriedade, a partir do momento em que qualquer disposição não garantir os valores para cuja promoção a norma foi estabelecida, impõe-se sua alteração, em atenção à mencionada necessidade de constante aperfeiçoamento do direito.

Todavia, ainda que de forma deficiente, percebe-se na Lei em estudo uma demonstração de que o contexto tão peculiar da Amazônia Legal foi levado em consideração pelo legislador, tratando-se de um passo na direção do maior propósito do direito: a vida.

Assim, com base nessas observações, é possível afirmar que, por possuir características bastante próprias, que refletem as peculiaridades da região amazônica e dos valores a que a propriedade deve servir naquele contexto, a propriedade resultante da regularização fundiária

\footnotetext{
${ }^{91}$ Conforme destacado na nota de rodapé 74 supra, importa recordar que, a respeito do limite máximo permitido para a área a ser regularizada, essa disposição foi objeto de inúmeras manifestações contrárias, que chegaram a denominar a Medida Provisória n 458, de 2009, de "MP da Grilagem” (SOB PROTESTO, 2008).
} 
em áreas rurais da Amazônia Legal constitui uma instituição específica da propriedade. Diante da consideração das características da região, associadas ao reconhecimento da existência de formas diversas de propriedade, ao que nos parece, a Lei n 11.952, de 2009 (BRASIL, 2009d) aproxima-se da ideia de Dagan (2011), assimilando a premissa realista do direito enquanto fenômeno social e conferindo as bases para a concepção de uma forma específica da propriedade. Entende-se, nesse sentido, que a legislação propõe, de certo modo, uma inovação institucional, baseada na realidade daquela região, reestruturando a propriedade sob a forma de uma instituição relacionada aos valores humanos existentes nas relações presentes naquele contexto, como a defesa do meio ambiente e das comunidades tradicionais, o desenvolvimento econômico sustentável, a inclusão social, a distribuição de riqueza, a autonomia e a valorização do trabalho.

Desse modo, considerando a abertura que a lei confere à propriedade, coerente com a visão realista do direito enquanto fenômeno social, é possível observar, como já sinalizado, um esforço legislativo na construção de uma nova instituição de propriedade, com contornos próprios e um regramento específico: a propriedade amazônica.

\subsection{Uma nova instituição da propriedade: a propriedade amazônica}

Como já mencionado, mais do que um tema acessório, a ser abordado de forma exclusivamente pragmática, a propriedade pode e deve ser enxergada como uma questão filosófica, com a abstração suficiente para que abarque uma abordagem social e economicamente estratégica, reconhecendo-se seu papel-chave na sociedade enquanto poderoso instrumento de justiça social. Para isso, sem que se afaste da realidade social e, por conseguinte, dos propósitos para os quais o direito foi criado, entende-se que a concepção deve ser abordada a partir de categorias mais estreitas, propondo-se, aqui, a adoção da definição de Dagan (2011) de propriedade enquanto um "guarda-chuva de um conjunto de instituições - instituições da propriedade - que carregam semelhanças entre si",92 (DAGAN, 2011, p. 42).

Entende-se, como já visto, que optar por categorias relativamente menores segue diretamente o compromisso de garantia que o direito sirva à vida, ao tempo em que preserva certa estabilidade e previsibilidade, fundamentais na organização da sociedade. Acrescenta-se

\footnotetext{
92 Tradução livre de: "Property is an umbrella for a set of institutions - property institutions - bearing family resemblances" (DAGAN, 2011, p. 42).
} 
que tais categorias permitem que os juristas desenvolvam uma distinção necessária para um tratamento de intimidade, mantendo-os perto da real "transação da vida" e conformando a lei a partir dos problemas humanos com os quais estejam lidando (DAGAN, 2011, p. XXIII). Assim, vale repetir a observação de Dagan (2011) de que, quando as categorias do direito estão em sintonia com as categorias da vida, "de modo que um senso de alerta acusa nossos devaneios teóricos, os juristas desfrutam de uma iluminação que só uma proximidade imediata fornece e de uma sensatez que só a realidade pode induzir"93 (OLIPHANT apud DAGAN, 2011, p. XXIII).

Nesse mesmo sentido, recorda-se as lições de Dewey (1941) de que, como fenômeno social, o direito não pode ser tratado como se fosse algo separado das demais dimensões da sociedade, devendo ser discutido com base na condição social na qual ele surge e nos propósitos para os quais foi criado (DEWEY, 1941, p. 117). Assim, a propriedade, como um meio para se alcançar determinados fins, deve ser justificada em termos de promoção de valores humanos.

A propriedade, portanto, normativamente, serve a um conjunto de valores sociais e individuais, incluindo-se, dentre eles, tanto utilidade e autonomia, quanto comunidade, trabalho, responsabilidade social e justiça distributiva. Conforme já dito, a pluralidade da propriedade reflete, justamente, a heterogeneidade de suas manifestações na vida real, o que não pode ser desconsiderado pelo ordenamento jurídico _ seja pelo legislador, pela doutrina, ou pelos magistrados ao tratarem do instituto nas mais diversas situações.

Com efeito, na abordagem da propriedade enquanto um conjunto de instituições, entende-se que as formas da propriedade possuem, ao lado da substância, grande importância para a estruturação da concepção. Trata-se, como vimos, de importantes molduras-padrão das relações interpessoais que surgem a partir do vínculo entre o homem e a coisa. Essa visão, pois, permite a consolidação das expectativas das pessoas, por ser dotada de relativa estabilidade, ao tempo em que expressa ideais normativos do direito para o centro das relações humanas.

Cada instituição é, desse modo, designada para enquadrar o equilíbrio específico entre os valores relevantes da propriedade que melhor se encaixa ao seu conjunto de características sociais. Por conseguinte, diferentes instituições vindicam diferentes pesos entre esses valores, dependendo do contexto, da relação social ali presente e da natureza do recurso. $\mathrm{O}$ direito de

\footnotetext{
${ }^{93}$ Tradução livre de: "When law's categories are in tune with those of life, so that a 'alert sense of actually checks our reveries in theory', lawyers uniquely enjoy 'the illumination which only immediacy affords and judiciousness which reality alone can induce"” (OLIPHANT apud DAGAN, 2011, p. XXIII).
} 
propriedade deve, assim, moldar e remoldar as instituições que irão otimizar a promoção dos valores humanos, sendo essa uma decorrência natural da visão realista do direito como um "grande laboratório humano em uma busca constante de aperfeiçoamento" (DAGAN, 2011, p. XXI).

Diante dessas considerações e com base na análise da norma, observa-se que a Lei $\mathrm{n}^{\circ}$ 11.952, de 2009 (BRASIL, 2009d) aproxima-se da ideia de Dagan (2011), assimilando a premissa realista do direito enquanto fenômeno social e fornecendo os contornos para a criação de uma forma específica da propriedade. Entende-se, como já salientado, que, de certo modo, a legislação propõe uma inovação institucional, conferindo importância à realidade daquela região e reestruturando a propriedade a partir dos valores humanos existentes nas relações presentes naquele contexto. Nesse sentido, arrisca-se a afirmar que a Lei $\mathrm{n}^{\circ} 11.952$, de 2009 (BRASIL, 2009d), evidenciando a adoção de uma visão múltipla da propriedade, estabelece as bases para a estruturação de uma nova instituição, a qual denominamos, aqui, de propriedade amazônica: a propriedade resultante da regularização fundiária de ocupações de terras públicas federais em áreas rurais no âmbito da Amazônia Legal.

Como vimos, a Lei $n^{\circ}$ 11.952, de 2009 (BRASIL, 2009d), confere importância ao conteúdo da propriedade, reconhecendo-o em determinadas situações de fato e atribuindo direitos e responsabilidades ao ocupante conforme as características daquela região. Traça, assim, a nosso ver, as linhas de uma instituição da propriedade com um equilíbrio bastante específico de valores, em que se revelam presentes, por exemplo, a responsabilidade ambiental, a tutela das comunidades tradicionais, o desenvolvimento sustentável da região, a inclusão social, o trabalho e a distribuição de riqueza.

A partir das disposições estabelecidas pela Lei, tratadas no capítulo anterior, é possível observar que a propriedade amazônica, por expressar valores relacionados ao contexto em que se insere, é construída de forma gradual.

Primeiramente, são definidas quais as terras não são passíveis de regularização ou que recebem um tratamento diverso daquele disposto na Lei. O dispositivo ressalva, assim, terras destinadas ao uso militar, áreas de reserva ambiental, as terras tradicionalmente ocupadas por populações indígenas, as terras das comunidades quilombolas e as terras das demais comunidades tradicionais (art. $4^{\circ}$, da Lei ${ }^{\circ}$ 11.952, de 2009 (BRASIL, 2009d)). Nesses casos, impede-se a regularização de determinada ocupação, fazendo prevalecer valores relacionados à proteção ambiental, à defesa do território nacional e à tutela das comunidades tradicionais. Ademais, a respeito da estruturação dessa instituição da propriedade e dos valores que a 
integram, recorda-se que a Lei, além de impedir a legitimação de ocupações sobre terras pertencentes a comunidades indígenas e quilombolas, estabelece que, em caso de conflito com o particular, a União priorizará a regularização em benefício das "populações tradicionais e outros grupos humanos, organizados por gerações sucessivas, com estilo de vida relevante à conservação e à utilização sustentável da diversidade biológica"94 (artigo $8^{\circ}$ da Lei $\mathrm{n}^{\circ}$ 11.952, de 2009 (BRASIL, 2009d)). Assim, além de conferir importância ao conteúdo das diversas estruturas das propriedades dentro do contexto em que se inserem, entende-se que a legislação assinala a importância da organização coletiva, reconhecendo a incidência da comunidade e da tutela das populações tradicionais como valores humanos presentes na propriedade amazônica.

Por seu turno, quanto à estruturação gradual dessa forma da propriedade, tem-se que, uma vez verificada a possibilidade de regularização, no primeiro momento, são estabelecidos os requisitos para que a ocupação seja regularizada. Já num segundo momento, com a expedição do título, são firmadas as condições para que a propriedade seja mantida nas mãos do novo proprietário.

Assim, num primeiro estágio, exige-se o cumprimento de determinados requisitos para que se reconheça a regularização, ou seja, para que seja conferido ao ocupante o status de proprietário, garantindo-lhe, a partir de então, uma maior proteção jurídica quanto à área em que exerce o cultivo e sua morada, devidamente delimitada, bem como, sua inclusão social, permitindo-lhe que passe a figurar como destinatário de outras políticas públicas, em virtude de ter tido sua situação regularizada.

Nessa etapa, portanto, deve ser comprovada, dentre outros elementos, a prática da cultura efetiva (artigo $5^{\circ}$, inciso III (BRASIL, 2009d)), privilegiando o conteúdo da relação proveniente do vínculo entre o homem e a coisa e evidenciando o trabalho como um importante valor relacionado à propriedade. Por esse requisito, só receberá o status de propriedade amazônica aquela relação que, efetivamente, proporcionar a cultura da terra.

Ao lado do cultivo, a legislação prevê, como requisito negativo, não ser proprietário de imóvel rural em qualquer parte do território nacional e não poder ter sido beneficiado por programa de reforma agrária ou regularização fundiária de área rural (artigo $5^{\circ}$, incisos II e V (BRASIL, 2009d)). Esse segundo requisito, de certa forma, sinaliza o reconhecimento da distribuição de riqueza como um valor presente na propriedade: aquele que já é proprietário, não pode ser beneficiado pela propriedade amazônica.

\footnotetext{
${ }^{94}$ Definição trazida pelo inciso X do art. 3o da Lei no 11.284, de 2 de março de 2006 (BRASIL, 2006a).
} 
Ademais, o ocupante, seu cônjuge ou companheiro, devem comprovar o exercício de ocupação e exploração direta, mansa e pacífica, por si ou seus antecessores, anterior a $1^{\circ}$ de dezembro de 2004 (artigo 5º inciso IV (BRASIL, 2009d)). Por esse requisito, vislumbra-se a preocupação da Lei com o contexto em que a propriedade está inserida, valorizando situações fáticas reais e consolidadas, bem como com o desenvolvimento social e econômico da região, utilizando o decurso do tempo como meio para evitar que sejam beneficiados meros especuladores e grileiros, esses, em geral, aproveitadores e predadores da terra.

\begin{abstract}
Esses predadores [os grileiros] são velhos conhecidos da Amazônia. Enviam seus pistoleiros carregados de armas e licença para matar. Empunham títulos de terra forjados numa rede de corrupção que começa nos cartórios e chafurda em intermináveis caminhos da justiça. Apregoam-se donos de milhares, milhões de hectares de floresta. Poucos aparecem como o que são. A maioria vive nas grandes cidades do Sul, Sudeste e Centro-Oeste, usam testas-de-ferro para cometer seus crimes, enquanto sentam-se com as unhas polidas para assistir a concertos de música clássica (BRUM, 2008, p. 160).
\end{abstract}

Por seu turno, no segundo momento da construção da propriedade amazônica, verificase a exigência de que sejam cumpridas determinadas condições a fim de que a propriedade se mantenha nas mãos do ocupante e não retorne ao patrimônio da União. Nesse segundo momento, percebe-se que outros valores também são evidenciados como inerentes à propriedade amazônica.

Conforme visto no capítulo anterior, nos termos do artigo 15, da Lei $\mathrm{n}^{\circ} 11.952$, de 2009 (BRASIL, 2009d), o referido título é expedido sob condição resolutiva pelo prazo de dez anos, sendo que, na hipótese de pagamento por prazo superior, a eficácia da cláusula resolutiva será estendida até a integral quitação.

Durante esse prazo, o já proprietário da terra deve comprovar, dentre outros requisitos, o aproveitamento racional e adequado da área (artigo 15, inciso I (BRASIL, 2009d)). Trata-se, aqui, da ratificação do reconhecimento pelo legislador do valor do trabalho como inerente à propriedade amazônica, evidenciando, assim como na expedição do título de domínio, a importância do conteúdo da relação amparada por essa instituição da propriedade.

Por sua vez, exige-se, durante o prazo referido, a averbação da reserva legal, a identificação das áreas de preservação permanente, devendo ser estabelecido, quando couber, o compromisso para sua recuperação, sendo definido, ainda, como causa de rescisão do título, o desmatamento que vier a ser considerado irregular em áreas de preservação permanente ou de reserva legal (artigo 15, incisos II e III e $\S 2^{\circ}$ (BRASIL, 2009d)). Entende-se que, por essas 
exigências, a propriedade amazônica transparece seus contornos específicos como uma nova instituição da propriedade. Nesse ponto, o legislador atribui ao proprietário responsabilidade ambiental, aperfeiçoando, assim, o controle e a fiscalização na Amazônia e permitindo a identificação dos responsáveis por eventuais lesões ao meio ambiente.

Nesse mesmo sentido, de atribuir e evidenciar a responsabilidade social enquanto valor inerente à propriedade, exige-se, do novo proprietário, a observância das disposições que regulam as relações de trabalho, também sob pena de que o bem retorne ao patrimônio público (artigo 15, inciso IV (BRASIL, 2009d)).

Por fim, dentre as condições firmadas no título, encontra-se o cumprimento quanto à forma de pagamento. Também a esse respeito, é possível observar a importância que assume o conteúdo das relações amparadas pela noção de propriedade. Isso porque a Lei reconhece diferentes nuances nas relações entre o proprietário e a terra e estabelece tratamentos distintos no que tange à precificação das alienações. Em primeiro lugar, até um módulo fiscal, conforme já visto, a alienação se dá de forma gratuita (artigo 11 (BRASIL, 2009d)), privilegiando os pequenos agricultores, que, em geral, são responsáveis pela agricultura familiar e vivem em condições de pobreza e alienação quanto a seus direitos fundamentais. Por sua vez. para os proprietários de áreas superiores a um até quatro módulos fiscais, a Lei prevê a possibilidade de redução de $50 \%$ dos valores das parcelas com base no programa Nossa Terra - Nossa Escola ${ }^{95}$ (artigo 12, $4^{\circ}$, (BRASIL, 2009d)). Corroborando com a adoção de tratamentos diferenciados, a disposição contida no parágrafo $1^{\circ}$ do artigo 12 prevê que a avaliação do imóvel terá como base o valor mínimo estabelecido em planilha referencial de preços, sobre o qual incidirão índices que considerem os critérios de ancianidade da ocupação, especificidades de cada região em que se situar a respectiva ocupação e dimensão da área. Nesse ponto, verifica-se o reconhecimento da necessidade de que seja priorizada a tutela dos pequenos proprietários, bem como da diversidade dentro da própria Amazônia Legal, elementos que irão incidir no preço da alienação de cada área.

No segundo momento de estruturação dessa instituição da propriedade, constata-se que a legislação restringe, também, o direito de alienação do proprietário. A propriedade amazônica, portanto, demonstrando aproximar-se de uma visão do direito enquanto fenômeno social, caracteriza-se por uma natureza condicional e relativa. Como visto, em áreas de até quatro módulos fiscais, o indivíduo só poderá alienar sua propriedade após o prazo de dez anos (artigo 12, $3^{\circ}$, (BRASIL, 2009d)). Para as propriedades com áreas superiores a quatro

\footnotetext{
${ }^{95}$ Art. 5 , Medida Provisória no 2.183-56, de 2001 (BRASIL, 2001).
} 
módulos fiscais, por sua vez, o prazo para que seja possível a transferência é de três anos, sendo condicionado, inclusive, para quem a propriedade será transferida, uma vez que o beneficiário originário deve cumprir as cláusulas resolutivas, e a alienação apenas será

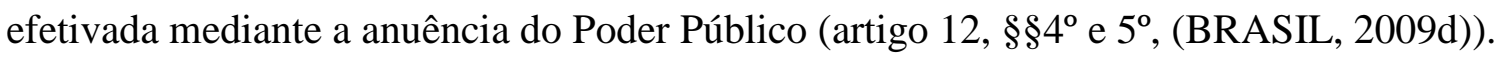

Diante dessas considerações, entende-se, conforme já dito, que a Lei nº 11.952, de 2009, adotando uma concepção múltipla de propriedade, admite a estrutura própria e contextual da propriedade resultante da regularização fundiária de terras públicas em áreas rurais na Amazônia Legal. A importância conferida ao conteúdo da propriedade, bem como a prevalência de valores específicos na sua formação nos levam a crer, portanto, na propriedade amazônica como uma instituição da propriedade, na forma como concebida por Dagan (2011).

Verifica-se, assim, que a propriedade fruto da regularização fundiária contém em sua definição a transformação da realidade fática em realidade jurídica, conferindo direitos e responsabilidades ao proprietário que, até então, encontrava-se em uma situação de ocupação juridicamente irregular. A propriedade amazônica, portanto, pode ser vista como um importante instrumento na busca de objetivos valiosos, como a agregação de bem-estar, a responsabilidade socioambiental e a justiça distributiva.

Assim, a configuração da propriedade amazônica apresenta-se como uma moldura para as interações entre pessoas e coisas, considerando o contexto da Amazônia Legal, as categorias das relações existentes e dos recursos que serão juridicamente tutelados. Tem como objetivo, tal como as demais instituições da propriedade, no seu próprio modo e com relação a uma esfera de aplicação prevista, um conjunto de valores humanos que podem ser promovidos por suas regras constitutivas, consolidando, portanto, as expectativas das pessoas que, então, podem prever as consequências de contingências futuras relacionadas à regularização e, assim, planejar e estruturar suas vidas.

Obviamente, tal como qualquer instituição da propriedade, a propriedade amazônica demanda um constante processo de identificação dos valores humanos que lhe são subjacentes, o que só vem a ratificar a importância de um estudo comprometido acerca do instituto. Em consonância à visão de Dagan (2011), a análise normativa da propriedade amazônica deve, portanto, recorrer aos efeitos materiais desse direito no comportamento das pessoas, considerando seu impacto expressivo e constitutivo. A propriedade amazônica, como as outras formas de propriedade _ assim como o direito em geral_, é, como já mencionado, um mecanismo coercitivo apoiado pelo poder do Estado e, portanto, suas prescrições devem ser justificadas em termos de promover valores humanos. Consequentemente, há que se reavaliar 
essa instituição da propriedade em termos de efetividade em promover os valores que lhe são relacionados e de sua continuidade e conveniência. A identificação dos valores e do equilíbrio entre eles presentes na estrutura da propriedade amazônica deve, portanto, aconselhar os atores jurídicos a revisitar as regras existentes e reexaminar a categorização jurídica que as organiza.

Ademais, é possível cogitar que a construção dessa instituição específica da propriedade aproximará o julgador dos problemas humanos existentes, conferindo-lhe a intimidade necessária para que proceda a suas decisões de forma contextual e normativa e afaste-se de deduções internas com base em formas totalmente abstratas e congeladas. Ao contrário de obscurecer as motivações subjacentes às escolhas dos julgadores, portanto, essa instituição da propriedade, que reflete os propósitos normativos implícitos nas regras jurídicas que a disciplinam, permitirá que os inevitáveis juízos de valor sejam realizados, porém, de forma racional, convergindo com os valores humanos que se pretende promover com a regularização fundiária na Amazônia Legal.

Por sua vez, considerando que a aplicação das normas integra a estrutura da própria concepção do direito, passa-se a abordar exemplos de consequências práticas possíveis a partir da adoção da visão ora defendida. Trata-se, como será visto, de algumas situações hipotéticas em que se entende que é possível antever quais seriam as decisões jurídicas adequadas, tomando-se como base os propósitos normativos coerentes à visão realista do direito, bem como a estruturação de uma instituição específica da propriedade pela legislação em estudo.

\subsection{Divagando: situações hipotéticas, como decidir?}

Muito embora já tenham se passado mais de cinco anos da edição da Lei no 11.952 , de 2009 (BRASIL, 2009d) e da implementação da política pública de regularização fundiária na Amazônia Legal, são raras as decisões dos tribunais sobre a matéria.

Em uma única manifestação do Tribunal Regional Federal da $1^{\mathrm{a}}$ Região, indagado sobre a ilegalidade de a Administração não ter concedido certidões de propriedade que possibilitassem ao impetrante receber o licenciamento ambiental da área regularizada, a Corte restringiu-se a analisar a inadequação processual, considerando a ilegitimidade passiva do Instituto Nacional de Colonização e Reforma Agrária (INCRA) ${ }^{96}$.

${ }^{96}$ Apelação em Mandado de Segurança $n^{\circ}$ 0002222277-26.2011.4.01.3600/MT, julgamento em 17/03/2014 (BRASIL, 2014). 
Por seu turno, entre as Cortes Superiores também não se encontra nenhuma manifestação acerca da matéria. Vale dizer que foi ajuizada Ação Direta de Inconstitucionalidade pela Procuradoria Geral da República, questionando alguns dispositivos da Lei no 11.952, de 2009 (BRASIL, 2009). Todavia, não houve, até a presente data, qualquer manifestação de mérito por parte do Supremo Tribunal Federal ${ }^{97}$.

Desse modo, até o momento, não havendo jurisprudência a respeito, não é possível aferir qual seria o posicionamento predominante entre os julgadores sobre a regularização fundiária na Amazônia Legal e os valores tutelados pela norma que trata da matéria.

Entretanto, a partir dos propósitos normativos evidenciados, com base nos quais se identifica a conformação de uma instituição específica da propriedade, com regramentos próprios, é possível desenvolver, a partir de situações hipotéticas, raciocínios sobre como seria uma decisão adequada a respeito de determinada situação de regularização fundiária em área rural, no âmbito da Amazônia Legal.

Entende-se que o referido exercício hipotético encontra sua importância na medida em que a aplicação das normas integra a estrutura da própria concepção de direito. Conforme destaca Dewey (1941), para o constante aprimoramento do direito, é necessário investigar, em termos de contexto de situações reais, as consequências de regras legais, das decisões jurídicas propostas e dos atos legislativos (DEWEY, 1941, p. 121).

\subsubsection{Fragmentação da propriedade rural}

Uma primeira questão que se pode cogitar refere-se à extensão do imóvel rural a ser regularizado, indagando-se sobre a importância da continuidade da exploração econômica ali desenvolvida. Entende-se por relevante o questionamento na medida em que cumpre aferir se a exploração econômica e, por conseguinte, o pedido de regularização, pode ser validamente objeto de fragmentações.

Em primeiro lugar, ainda que não se trate de uma decisão específica sobre a regularização fundiária na Amazônia Legal, revela-se pertinente observar decisões judiciais anteriores a respeito do que seriam, efetivamente, os imóveis rurais. Essa primeira investigação revela-se importante para que se possa definir qual a orientação dos Tribunais a respeito da concepção desse imóvel, seja para adotá-la seja para refutá-la diante das especificidades do contexto amazônico.

\footnotetext{
${ }^{97}$ Trata-se da ADI 4269, protocolada em 09 de julho de 2009 (BRASIL, 2009i).
} 
Pois bem. Acerca da caracterização do imóvel rural, o Supremo Tribunal Federal pronunciou-se no sentido de que consiste em uma "unidade da exploração econômica do prédio rústico"98.

É que, segundo consignei na decisão agravada, está "provado nos autos, documentalmente, que a gleba de domínio dos impetrantes é plenamente individualizada, a despeito da comunhão de matrícula de registro imobiliário, conforme certidão expedida pelo Cartório Imobiliário da Comarca de Crateús/CE (fl. 15)". Em outras palavras, embora a titular do cartório não tenha aberto um novo número de matrícula para cada quinhão - o que deveria ter feito, reconheça-se -, os registros imobiliários, devidamente averbados, separaram, geograficamente, as partes de cada qual dos antigos condôminos da fazenda "Serrote". [...] Tem razão a agravante quando afirma que, para fins de desapropriação para reforma agrária, importa mais a situação do imóvel em seu "âmbito material" do que do "ponto de vista jurídico". Essa é a ideia subjacente ao acórdão do MS 24.573, redigido pelo Ministro Eros Grau. Nesse julgado, o Supremo Tribunal Federal, reformulando sua antiga jurisprudência, desconsiderou a regra da saisine e passou a entender o imóvel rural como "a unidade da exploração econômica do prédio rústico"99 (BRASIL, 2013).

Em muitos dos casos tratados pela Corte Constitucional ${ }^{100}$, entendeu-se que o fracionamento teve por finalidade burlar o processo de desapropriação, frustrando, assim, sua destinação à reforma agrária, a despeito da realidade fática em que a propriedade era apenas uma. Observa-se, pois, que aquele Tribunal Superior, também para imóveis rurais situados em outras regiões, confere prevalência à situação real do imóvel em detrimento da abstração fictícia registral, o que condiz com os propósitos da propriedade amazônica, tratando-se, assim, de uma visão coerente com aquela revelada pela legislação ao tratar da regularização no âmbito da Amazônia Legal.

Por seu turno, transportando a ideia para o contexto da regularização fundiária, pode-se indagar sobre a eventual pretensão de ocupantes de terra pública federal conseguirem, mediante o regramento da Lei $\mathrm{n}^{\mathrm{o}}$ 11.952, de 2009 (BRASIL, 2009d), diversos registros imobiliários. Tratar-se-ia de uma situação em que diversas pessoas se apresentariam como pretensos ocupantes em áreas, que, na realidade, não se encontrariam individualizadas. Vale dizer que a situação é perfeitamente possível na medida em que imóveis até um módulo fiscal,

\footnotetext{
${ }^{98}$ Agravo Regimental no Mandado de Segurança no 22.138, julgado em 04 de março de 2013 (BRASIL, 2013).

99 Vale ressaltar que foi negado provimento ao Agravo Regimental no Mandado de Segurança $\mathrm{n}^{\circ} 22.138$ (BRASIL, 2013), tendo o Ministro Relator, Dias Toffoli, entendido que, "nesse caso concreto, porém, não se tem um único imóvel rural, de propriedade de vários herdeiros, à espera da partilha, nem partes ideais de um condomínio averbadas "no registro imobiliário de forma abstrata"'. Assim, o julgamento ora trazido demonstra o entendimento atual do Supremo Tribunal Federal a respeito, embora a agravante não tenha conseguido comprovar seus argumentos.

${ }^{100}$ Cf. Mandados de Segurança nº 24.573 (BRASIL, 2006c) e 26.129 (BRASIL, 2007b).
} 
por exemplo, são alienados gratuitamente, dispensadas, ainda, as custas e emolumentos registrais.

Conforme visto acima, a regularização fundiária pressupõe a atribuição de efeitos jurídicos e, por conseguinte, de proteção estatal a situações de fato, alcançando as relações que se formam a partir do vínculo entre o homem e a terra. Verificou-se, assim, como um dos propósitos da norma, privilegiar as situações que se encontram consolidadas na vida real, de modo a tutelar os agricultores que, de fato, conferem uma destinação adequada e produtiva à terra e, por conseguinte, promovem o desenvolvimento sustentável da região.

Nesse sentido, diante da situação em tela, é possível concluir que, se a área não está faticamente dividida e ocupada, não sendo explorada por pessoas diversas ou apresentando uma estrutura produtiva própria, terá que ser objeto de uma regularização fundiária única, conformando, por conseguinte, uma única propriedade. De outro turno, se, na área, pode se verificar a individualização, na prática, dessas ocupações, em razão, por exemplo, da diversificação da estrutura produtiva ou da ausência de qualquer relação entre os ocupantes, ela será titulada de acordo com as ocupações existentes, abrindo-se correspondentes matrículas e registros próprios.

Tal raciocínio é possível, portanto, a partir de decisões anteriores a respeito do que seria o imóvel rural, bem como da consideração dos propósitos normativos da Lei de Regularização, que revelam a importância do contexto fático da Amazônia Legal e pressupõem a exploração econômica como aquela efetiva e contínua, executada e exteriorizada no mundo fático pelo ocupante, carregando, em si, os valores a que servem a propriedade amazônica.

Recorda-se aqui, tal como já ressaltado, que essa instituição da propriedade expressa um equilíbrio específico de valores humanos em conformidade com o tipo de relação social efetivamente existente e com a natureza do recurso no contexto da Amazônia Legal. Cabe, portanto, ao direito, diante da controversa convivência de diferentes valores dentro da propriedade, oferecer os princípios e as regras para a acomodação do que Dagan (2011) denomina de "feliz pluralidade" (DAGAN, 2011, p. XVIII). 


\subsubsection{Titulação coletiva}

Dando continuidade à análise de algumas situações hipotéticas que permitam construir raciocínios com base nos propósitos da norma, evidenciando como seria decidida de forma adequada uma determinada situação de regularização, no âmbito da Amazônia Legal, questiona-se se os beneficiários dessa regularização fundiária podem ser titulados coletivamente.

A resposta a essa questão decorre também da finalidade a que serve a propriedade amazônica e dos propósitos da norma na tutela de valores humanos.

À primeira vista, considerando a titulação coletiva como sendo aquela a ser efetivada em nome de mais de uma pessoa, a solução a essa questão pode ser encontrada também a partir do raciocínio feito acima, abarcando a definição do imóvel rural pelo Supremo Tribunal Federal (imóvel rural como unidade de exploração econômica) como uma concepção apropriada para o objeto da regularização fundiária amazônica. Nesse sentido, basta que se verifique, em cada caso concreto, quem é, de fato, o sujeito que exerce a exploração econômica na respectiva unidade física de forma contínua. Vale dizer, se a exploração econômica do imóvel rural se efetivar por uma pessoa, ela será a beneficiária, singularmente. De outro turno, se a unidade econômica for explorada por várias pessoas, elas serão, de fato, os ocupantes do imóvel singular, devendo ser expedido o título coletivo de propriedade, em seus respectivos nomes. Assim, haveria compatibilidade do objeto da regularização com o sujeito que explora o imóvel, transformando a realidade fática em jurídica, de acordo com a situação tutelada.

Todavia, sobre esse questionamento, mostram-se oportunas algumas ponderações. Também aqui uma análise comprometida com os propósitos da Lei n ${ }^{\circ} 11.952$, de 2009 (BRASIL, 2009d) revela-se importante para se aferir se é permitido que várias pessoas sejam tituladas de forma coletiva em um único imóvel rural. Isso porque o artigo $5^{\circ}$, caput, da Lei ${ }^{\circ}$ 11.952, de 2009 (BRASIL, 2009d), sugere que haveria um limite subjetivo para a titulação condominial, uma vez que se refere restritiva e especificamente ao "ocupante e seu cônjuge ou companheiro". Assim, da literalidade de tal dispositivo, se extrai que somente uma pessoa, se solteira (“o ocupante”), ou no máximo duas (“o ocupante e seu cônjuge” ou "o ocupante e seu companheiro"), poderiam ser beneficiados com a regularização fundiária.

Também o Decreto $\mathrm{n}^{\circ}$ 6.992, de 2009 (BRASIL, 2009f), que regulamenta a mencionada lei, não esclarece expressamente a situação, embora inove ao possibilitar a 
titulação coletiva aos conviventes em regime de união homoafetiva ${ }^{101}$. Nesse ponto, vale destacar que o próprio regulamento da regularização fundiária em área rural sinaliza a importância dos propósitos da norma, corroborando a ideia de que a propriedade amazônica deve servir aos valores humanos presentes nas relações interpessoais.

Por sua vez, a partir de uma análise contextual e normativa, percebe-se a viabilidade da titulação coletiva, ainda que se tratando de mais de duas pessoas, em detrimento do que a literalidade da lei, num primeiro momento, pareça sugerir. A esse respeito, conforme já visto, recorda-se que valores relacionados ao trabalho e à comunidade integram a propriedade amazônica, o que acarreta a proteção de situações em que vários indivíduos, coletivamente, conferem à terra o cultivo e o aproveitamento adequado, com responsabilidade social e ambiental.

Tal entendimento é evidenciado, ainda, a partir da previsão de que o Ministério do Desenvolvimento Agrário (MDA) possui competência plena para regularizar as ocupações nas áreas federais das comunidades tradicionais na Amazônia Legal, ressalvada a regularização fundiária de populações tradicionais em unidades de conservação e em projetos de assentamento agroextrativista. Nos termos do artigo $4^{\circ}$, $2^{\circ}$, da Lei $\mathrm{n}^{\circ} 11.952$, de 2009 (BRASIL, 2009d), as comunidades quilombolas submetem-se a regramento específico e serão regularizadas com base no Decreto $\mathrm{n}^{\circ}$ 4.887, de 20 de novembro de 2003 (BRASIL, 2003). Com efeito, quando não houver legislação específica dispondo sobre as áreas ocupadas por comunidades tradicionais aplica-se plenamente a Lei $\mathrm{n}^{\circ}$ 11.952, de 2009 (BRASIL, 2009d), conferindo-se, ainda, prioridade a essas comunidades, quando houver conflito com particulares, na forma do artigo $8^{\circ}$, inciso I, da Lei $\mathrm{n}^{\circ}$ 11.952, de 2009 (BRASIL, 2009d).

Desse modo, percebe-se que, além de se priorizar o conteúdo das diversas estruturas das propriedades dentro do contexto em que se inserem, a legislação assinala a importância da organização coletiva, reconhecendo a incidência da comunidade como um valor humano presente na propriedade, sendo possível, assim, entender que é plenamente viável a titulação coletiva quando presentes os requisitos para tanto.

\footnotetext{
${ }^{101}$ Artigo 14 do Decreto ${ }^{\circ}$ 6.992, de 2009. Os títulos de domínio e de concessão de direito real de uso serão expedidos: I - em nome da mulher e do homem, obrigatoriamente, quando casados ou convivendo em regime de união estável; II - em nome dos conviventes, havendo união homoafetiva; e III - preferencialmente em nome da mulher, nos demais casos (BRASIL, 2009f).
} 


\subsubsection{A titulação de terras quilombolas por terceiros}

Ainda a respeito da titulação de terras pertencentes a comunidades tradicionais, é possível se levantar outra hipótese em que se verifica um conflito aparente, a ser objeto de questionamento. Conforme já visto, a Lei $\mathrm{n}^{\circ} 11.952$, de 2009, em seu artigo $4^{\circ}$, caput, prevê que não são passíveis de regularização as terras ocupadas por comunidades indígenas (BRASIL, 2009d). Por sua vez, às terras ocupadas por comunidades quilombolas é destinado um tratamento diverso, previsto não no caput, mas no $\S 2^{\circ}$ do referido artigo, que dispõe que "[a]s terras ocupadas por comunidades quilombolas ou tradicionais que façam uso coletivo da área serão regularizadas de acordo com as normas específicas, aplicando-se-lhes, no que couber, os dispositivos dessa Lei” (BRASIL, 2009d).

Uma primeira leitura do dispositivo, de forma isolada, poderia nos levar a pensar que as terras ocupadas por comunidades quilombolas são passíveis de regularização, o que, por seu turno, poderia ocorrer por qualquer pessoa que, de algum modo, ocupe parte da área que, a princípio, pertenceria àquela comunidade tradicional.

Todavia, uma leitura contextualizada da propriedade, coerente com os propósitos da norma e o equilíbrio de valores presente nessa situação, não permite tal interpretação. Isso porque, como visto, a tutela das comunidades tradicionais integra a estrutura da propriedade amazônica, que reconhece a prevalência dos direitos de ocupação por esse grupos sociais. Assim, embora possa se submeter a um regime formal diverso do conferido às comunidades indígenas, para as quais é previsto um procedimento administrativo de demarcação ${ }^{102}$, o fato é que não é possível concluir, com base em uma análise normativa e contextual, que a regularização fundiária não tutela os direitos das comunidades quilombolas na mesma medida em que protege os direitos indígenas. Desse modo, considerando os propósitos normativos da Lei $n^{\circ}$ 11.952, de 2009 (BRASIL, 2009d), a aplicação do artigo $4^{\circ} \S^{\circ}$ deve orientar-se no sentido de que, se as terras pertencem às comunidades quilombolas, a regularização pode ocorrer tão somente em benefício delas próprias.

Assim, com base nesse singelo exercício hipotético, é possível se pensar em como seriam decisões coerentes, fundadas na razão, a respeito da regularização fundiária de ocupações em áreas rurais na Amazônia Legal. Verifica-se, nesse sentido, a necessidade de um raciocínio contextual e conectado aos propósitos da norma e aos valores presentes na propriedade amazônica, a fim de que o direito atinja, de fato, os fins para os quais foi criado.

\footnotetext{
${ }^{102}$ O referido procedimento é previsto no Decreto no 1775, de 1996 (BRASIL, 1996).
} 
Entretanto, como se verá a seguir, a própria norma apresenta, em alguns dispositivos, incoerências com os seus propósitos, afastando-se dos valores a que, a princípio, foi estabelecida para promover. Entende-se que esse distanciamento também deve ser considerado pelos julgadores quando da apreciação de situações no caso concreto, servindo de ponto de partida para o necessário aperfeiçoamento constante do direito.

\subsection{Incoerências: propósitos normativos versus dispositivos legais}

Como mencionado, é possível observar que a Lei $\mathrm{n}^{\circ} 11.952$, de 2009 (BRASIL, 2009d), em determinados pontos, conflita com os propósitos revelados a partir de uma análise contextual e conjunta da norma. Trata-se de previsões que se distanciam dos valores subjacentes à propriedade amazônica, já se vislumbrando, aqui, a necessidade de um aperfeiçoamento normativo.

A esse respeito, importa mencionar que a Ação Direta de Inconstitucionalidade $\mathrm{n}^{\circ}$ 4269 evidencia algumas dessas incongruências, amparando, todavia, suas razões em inobservâncias a princípios amplamente abstratos ${ }^{103}$. Conforme se verifica no teor da peça inicial da referida ação, alega-se, sobretudo, a não observância ao princípio da razoabilidade, da proporcionalidade e da isonomia para se justificar a necessidade de revisão da Lei quanto a determinados dispositivos (BRASIL, 2009h).

Entretanto, conforme será abordado a seguir, entende-se que, na verdade, o que existe são incoerências entre a lei e seus propósitos, uma vez que os dispositivos que ora se passa a abordar não traduzem os valores que a norma pretendeu tutelar. Cuida-se, pois, a nosso ver, de incoerências internas, não havendo a necessidade de se buscar, em princípios amplamente abstratos, argumentos para se defender a existência de uma contradição revelada a partir de uma análise contextual e normativa da própria legislação.

Assim, é possível perceber que os direitos das comunidades tradicionais, a promoção da inclusão, a justiça social, o controle e a fiscalização do desmatamento na Amazônia em determinados momentos não recebem o tratamento devido para que os valores humanos expressados pela propriedade amazônica sejam, efetivamente, assegurados.

\footnotetext{
103 Questiona-se, por meio da ADI n 4269 , a constitucionalidade dos artigos $4^{\circ}, \S 2^{\circ}$ (interpretação conforme a Constituição); 13; $15 \S 1^{\circ}$ (interpretação conforme a Constituição); e $15 \S \S 4^{\circ}$ e $5^{\circ}$, da Lei n $^{\circ} 11.952$, de 25 de junho de 2009 (BRASIL, 2009h).
} 
4.4.1 Artigo 13: dispensa de vistoria prévia

Uma primeira incongruência perceptível na legislação da regularização fundiária da Amazônia Legal pode ser vista no artigo 13, da Lei n 11.952 , de 2009, que estabelece:

\begin{abstract}
Art. 13. Os requisitos para a regularização fundiária dos imóveis de até 4 (quatro) módulos fiscais serão averiguados por meio de declaração do ocupante, sujeita a responsabilização nas esferas penal, administrativa e civil, dispensada a vistoria prévia. Parágrafo único. É facultado ao Ministério do Desenvolvimento Agrário ou, se for o caso, ao Ministério do Planejamento, Orçamento e Gestão determinar a realização de vistoria de fiscalização do imóvel rural na hipótese prevista no caput deste artigo (BRASIL, 2009d).
\end{abstract}

Entende-se que a referida previsão, ao dispensar a vistoria prévia nos imóveis rurais, distancia-se dos propósitos subjacentes à proteção da propriedade amazônica. Como já abordado, a regularização fundiária confere tutela estatal a situações de fato, ao conteúdo da propriedade, alcançando as relações que se formam a partir do vínculo entre o homem e a coisa. Entre os propósitos da norma, percebeu-se, portanto, o de privilegiar situações que se encontram consolidadas na vida real, atribuindo proteção àqueles pequenos e médios agricultores que, de fato, conferem uma destinação produtiva à terra e, assim, promovem o desenvolvimento sustentável da região.

Por sua vez, observou-se, ainda, a preocupação do legislador com as consequências fáticas da norma, estabelecendo, além da vistoria prévia como mecanismo de fiscalização, a criação do Grupo Executivo Intergovernamental - GEI, com a finalidade de, entre outras atribuições, acompanhar a execução das ações e avaliar seus resultados (artigo 35 da Lei no 11.952, de 2009 (BRASIL, 2009d) e Decreto de 27 de abril de 2009 (BRASIL, 2009c)). Como assinalado, essa visão converge com a abordagem realista, levando-nos a crer na inclinação legislativa no sentido de reconhecer a importância dos efeitos materiais da regularização fundiária amazônica, os quais integram uma análise normativa adequada e voltada à proteção dos valores inerentes às relações tuteladas e do contexto da Amazônia Legal.

Desse modo, entende-se que a dispensa de vistoria prévia nas áreas de até quatro módulos fiscais não atende aos propósitos da norma. Isso porque a referida previsão abre espaço para que títulos de propriedade ou concessões de direito real de uso sejam outorgados a pessoas que não ocupam diretamente as áreas reivindicadas de forma mansa e pacífica desde dezembro de 2004, ou que nelas não exerçam qualquer cultura. Privilegia, pois, a fraude, aumentando o risco de que sejam favorecidos meros especuladores e grileiros e prejudicando 
o desenvolvimento e a proteção adequada da Amazônia Legal, situação essa que, como vimos, é amplamente combatida pela própria norma, contextual e conjuntamente considerada.

A ausência de vistoria impede, ainda, que se verifique a existência, no local, de conflitos fundiários, em especial, situações envolvendo terras ocupadas por indígenas, quilombolas e populações tradicionais. Desse modo, tem-se que, a partir da previsão contida no artigo 13 da Lei de Regularização, surge a possibilidade de que essas comunidades venham a ser prejudicadas, perdendo suas terras tradicionais ou agravando os conflitos entre esses grupos e indivíduos.

Assim, considerando a realidade existente na Amazônia Legal, sobre a qual foram construídas as bases para uma proteção adequada dos valores humanos prevalecentes nas relações ali estabelecidas, é possível concluir que o referido dispositivo não conduz à finalidade objetivada, de proteção aos direitos de grupos étnicos e culturais, de realização de justiça social na distribuição de terras e de desenvolvimento sustentável da região. Ao contrário, entende-se que a medida ora questionada, ao dispensar a vistoria prévia, expõe a grave e desnecessário risco as relações amparadas pela propriedade amazônica, bem como o desenvolvimento da região amazônica.

4.4.2 Artigo $15, \S 2^{\circ}$ : a proteção do meio ambiente amazônico

O $2^{\circ}$ do artigo 15 da Lei $n^{\circ} 11.952$, de 2009, prevê:

\begin{abstract}
O desmatamento que vier a ser considerado irregular em áreas de preservação permanente ou de reserva legal durante a vigência das cláusulas resolutivas, após processo administrativo, em que tiver sido assegurada a ampla defesa e o contraditório, implica rescisão do título de domínio ou termo de concessão com a consequente reversão da área em favor da União (BRASI, 2009d).
\end{abstract}

A despeito do que dispõe o artigo acima colacionado, uma das principais finalidades da legislação é a de proteger o meio-ambiente, considerada a espetacular biodiversidade da região amazônica e sua importância ambiental para o planeta. A propriedade resultante da regularização fundiária naquela região reflete, como visto, valores ligados à responsabilidade social e, sobretudo, ao meio-ambiente, tutelando a necessária sustentabilidade do desenvolvimento econômico dos Estados integrantes da Amazônia Legal. A partir de uma 
análise contextual e normativa da legislação, portanto, vimos que a legislação confere um tratamento bastante próprio à propriedade resultante da regularização fundiária, fornecendo as bases para que se entenda que se trata, na verdade, de uma instituição específica da propriedade, intimamente ligada à peculiar realidade em que está inserida.

Todavia, da leitura do referido dispositivo, verifica-se que o legislador previu que apenas o desmatamento irregular realizado em área de preservação permanente ou de reserva legal daria ensejo à reversão da área em favor da União, não abordando o desmatamento irregular em geral.

Constata-se, assim, também quanto a esse dispositivo, o distanciamento do legislador de um dos grandes propósitos da norma: a tutela do meio ambiente. Na construção da propriedade amazônica, coerente com a proteção dos valores humanos presentes nas relações estabelecidas naquele contexto, não se pode admitir, portanto, a prática de qualquer tipo de desmatamento irregular, independentemente da área em que ocorra, devendo ser proibida todas as suas demais hipóteses, tal como se dá, a título meramente exemplificativo, com o desmatamento sem autorização competente, sem plano de manejo ou sem estudo de impacto ambiental.

No caso presente, vale dizer, que a referida previsão vai de encontro, inclusive, à exigência de aproveitamento racional e adequado presente na estrutura da propriedade amazônica e previsto como uma das condições para a manutenção da propriedade. Entende-se que essa exigência legal ratifica o dever do ocupante de não provocar o desmatamento irregular em qualquer parte da área regularizada, abrangendo, ainda, sua responsabilidade quanto à recuperação das lesões ambientais que tenha causado anteriormente.

Percebe-se, portanto, conforme já mencionado, que a própria Lei, em alguns pontos, distancia-se dos seus propósitos, exigindo-se uma análise contextual e normativa, a fim de que seja possível alcançar e tutelar, de forma apropriada, os valores humanos para os quais a propriedade amazônica fora criada. A esse respeito, assinala-se, mais uma vez, que a propriedade amazônica, como um mecanismo coercitivo sustentado pelo poder estatal, deve ser justificada enquanto facilitadora da promoção de valores humanos, devendo, por conseguinte, ser reavaliada em termos de sua efetividade na realização desses valores.

Nesse sentido, importa recordar as observações de Dagan (2011) acerca da necessidade de se abordar as formas, previamente estabelecidas, normativamente, mais que dedutivamente, uma vez que apenas o raciocínio normativo pode acentuar os benefícios das nossas instituições da propriedade. Vale dizer, ainda com base nas pontuações do autor, que essa 
forma de raciocínio não prejudica a relativa estabilidade das instituições da propriedade, porquanto as expectativas das pessoas relacionam-se mais com o "caráter" da instituição do que com suas regras pontuais (DAGAN, 2011, pp. 33-34). Esse caráter da instituição da propriedade, por sua vez, é estabelecido justamente a partir de seus propósitos e, consequentemente, dos valores, individuais e sociais, aos quais deve servir, devendo ser objeto de uma cuidadosa análise, com o objetivo de orientar as decisões dos julgadores e, desse modo, promover e permitir a efetiva fruição desses valores.

Assim, com base nas considerações aqui trazidas, é possível entender que a Lei $n^{\circ}$ 11.952, de 2009, ao aproximar-se da visão realista de propriedade proposta por Dagan (2011), nos permite cogitar na construção de uma instituição específica, a propriedade amazônica, que, refletindo os propósitos normativos implícitos nas regras jurídicas que a disciplinam, permitirá a aproximação do julgador dos reais problemas humanos existentes na Amazônia Legal. Esse raciocínio, por seu turno, possui importantes consequências práticas, uma vez que, ao contrário de obscurecer as motivações subjacentes às escolhas dos julgadores, possibilita que os inevitáveis juízos de valor sejam realizados de forma racional, convergindo com os propósitos da norma e, por conseguinte, com os valores humanos que se pretende promover com a regularização fundiária na região amazônica. 


\section{CONCLUSÃO}

O conceito de propriedade possui grande relevância para um regime jurídico que pretende assegurar importantes valores individuais, como autonomia e merecimento, apresentando-se como um escudo indispensável em face do Estado e da própria comunidade. Todavia, muito mais que apenas um meio a serviço do indivíduo, a propriedade é um instrumento na busca de outros objetivos extremamente valiosos na sociedade, como a responsabilidade social e a justiça distributiva. Assim, independentemente da teoria que se adote quanto às bases da fundamentação da propriedade e a organização da sociedade, percebe-se que a concepção carrega em si inúmeros valores, sociais e individuais. Na verdade, os diferentes posicionamentos a respeito da propriedade, conjuntamente considerados, levamnos a refletir que o conceito não se resume a uma ideia de pertencimento individual, marcado pela exclusão e exclusividade em favor do(s) proprietário(s). Liberdade, igualdade, responsabilidade e justiça são, portanto, noções diretamente relacionadas à propriedade.

Nesse sentido, entende-se que, mais do que um tema acessório, a ser tratado de forma pragmática e particularizada, a propriedade desempenha um papel-chave na sociedade e deve ser analisada abstratamente, como uma questão filosófica, permitindo que se pense a priori a respeito e que, por conseguinte, se possa adotar uma abordagem social e economicamente estratégica já na construção da concepção.

Entretanto, como assinala Waldron (2012), diante da já existente má distribuição e exploração da propriedade, são poucas as pesquisas sobre as tentativas presentes na história de trazer à tona quais seriam os verdadeiros princípios sobre os quais um sistema ideal de propriedade deve repousar. Desse modo, considerando que não se pode perder de vista os valores a que a propriedade deve servir, há que se pensar em um sistema comprometido com a sociedade como um todo, relacionado às mais variadas dimensões sociais, ao invés de um sistema de mercado puro da propriedade privada.

Entende-se, pois, que, atualmente, não há espaço para uma visão reducionista da propriedade, sendo essa denominação a roupagem de um complexo bastante distinto e independente de relações, no qual, como mencionado, estão presentes inúmeros valores, equilibrados de formas diversas e conectados ao contexto em que estão inseridos. A pluralidade da propriedade reflete, justamente, a heterogeneidade de suas manifestações na vida real, constatação essa que, a nosso ver, possui extrema relevância para a construção de uma concepção de propriedade comprometida socialmente. Do mesmo modo, percebe-se que 
também a diversidade própria do pluralismo de valores, presente em nossa sociedade e reconhecida por nosso ordenamento, implica a ideia de que diferentes valores ou diferentes equilíbrios devem orientar diferentes áreas do direito e da vida, influenciando, por conseguinte, a maneira como a propriedade deve ser enxergada. Frente a essas constatações e considerando a controversa convivência entre os diversos valores presentes na concepção de propriedade, entende-se que cabe ao direito oferecer os princípios e as regras para a acomodação do que Dagan (2011) denomina de "feliz pluralidade".

Nesse sentido, reconhecendo essa heterogeneidade das manifestações do instituto e a mencionada pluralidade de valores, Dagan (2011) constroi sua concepção contemporânea da propriedade. Inspirado em uma visão realista, o autor parte da premissa do direito enquanto uma instituição em movimento, um fenômeno social, que, portanto, não pode ser encarado como algo acabado, mas em constante aperfeiçoamento. Como fenômeno social, o direito não pode, ainda, ser tratado como se fosse algo separado das demais dimensões da sociedade, devendo ser discutido em termos da condição social na qual ele surge e dos propósitos para os quais foi criado (DEWEY, 1941, p. 117). Desse modo, haja vista que a propriedade _ tal como o direito, em geral _ representa um meio para se alcançar determinados fins, sendo um mecanismo coercitivo apoiado pelo poder do Estado, suas prescrições devem ser justificadas em termos de promoção de valores humanos. Seguindo essa linha de pensamento, a análise jurídica precisa tanto de dados empíricos quanto de juízos normativos. As formas já existentes possuem grande importância, porém, o direito, como algo mutável, não detém um significado totalmente preestabelecido, reconhecendo-se que juízes e tribunais possuem um importante papel na sua criação, ao lhe atribuir sentido nos casos concretos.

Assim, partindo dessas premissas, Dagan (2011) define a propriedade com base em categorias mais estreitas, conceituando o instituto como um "guarda-chuva de um conjunto de instituições - instituições da propriedade - que carregam semelhanças entre si" ${ }^{104}$ (DAGAN, 2011, p. 42). Entende-se que a proposta do autor permite o diálogo com os mais diversos posicionamentos a respeito da propriedade, na medida em que defende a importância tanto da forma quanto do conteúdo da concepção, ressaltando que cada uma dessas instituições apresenta um equilíbrio específico entre valores humanos, considerando a natureza das relações que surgem a partir do vínculo entre o homem e a coisa, o recurso em jogo e o contexto em que estão inseridos. Assinala, pois, a relevância da substância do conceito

104 Tradução livre de: "Property is an umbrella for a set of institutions - property institutions - bearing family resemblances" (DAGAN, 2011, p. 42). 
juntamente com a necessidade de se pensá-lo de maneira abstrata, enquanto formas previamente estabelecidas, permitindo que a concepção, desde a sua construção, comporte uma abordagem social e economicamente estratégica. Dessa maneira, enquanto forma, as instituições da propriedade correspondem a molduras padrão de interações interpessoais que consolidam as expectativas das pessoas e expressam os ideais normativos do direito para o centro das relações humanas; enquanto substância, cada instituição da propriedade tem como objetivo, no seu próprio modo e com relação a alguma esfera de aplicação prevista, um conjunto de valores humanos que podem ser promovidos por suas regras constitutivas.

Ao adotar esse posicionamento, o autor, portanto, reconhece a importância de uma análise contextual e normativa das diferentes formas da propriedade. Assim, se a propriedade é entendida como instituições, o apelo a essas formas não pode ser tido como a parte final da análise jurídica, mas demanda um constante e cauteloso processo de identificação dos valores humanos que lhes são subjacentes, a fim de promovê-los adequadamente.

Com base nas premissas firmadas e na concepção proposta, observa-se, como uma dessas manifestações da propriedade na vida real, a regularização fundiária das ocupações incidentes em terras da União, em áreas rurais, no âmbito da Amazônia Legal, prevista na Lei $\mathrm{n}^{\mathrm{o}}$ 11.952, de 2009. Entende-se que, ao considerar o contexto amazônico e os valores presentes nas relações de ocupação de terras públicas, o legislador aproxima-se da visão de inspiração realista ora abordada.

Como visto ao longo do presente estudo, já nos primeiros artigos da Lei, percebe-se a diferenciação, pelo legislador, dos conteúdos das propriedades, fazendo transparecer sua concepção pluralista, bem como uma abordagem da propriedade a partir de categorias mais estreitas. Reconhece-se, por conseguinte, que o instituto pode assumir formas diversas, com regramentos específicos, de acordo com o contexto e com as relações interpessoais que representa. Ademais, ao estabelecer requisitos e condições determinados para que seja possível a regularização fundiária na Amazônia Legal, o referido diploma legal confere à propriedade fruto desse processo um tratamento específico, confirmando, a nosso ver, a adoção de uma visão contextualizada da propriedade, que, uma vez inserida no cenário rural amazônico, reflete uma forma peculiar de realidade fundiária, com características diversas das demais regiões do Brasil. Por meio da referida regularização, pois, atribuem-se não apenas direitos, mas responsabilidades aos ocupantes de terras públicas federais, tratando-se de um importante instrumento de legitimação de posse, sobretudo, para os pequenos agricultores, 
cuja realidade é, em geral, de fragilidade econômica, baixa organização política e incapacidade de inserção de seus interesses na esfera pública.

Nesse sentido, entende-se que a referida legislação prevê, consoante a proposta de Dagan (2011), uma importante moldura-padrão das relações interpessoais que surgem a partir do vínculo entre o ocupante, que preenche os requisitos legais, e a terra pública federal no contexto amazônico. Seguindo essa linha de raciocínio, a partir de uma análise normativa e contextual e considerando a premissa realista quanto à fundamental importância da aferição dos propósitos do direito, verifica-se, entre as finalidades da norma, as de assegurar os direitos das comunidades tradicionais, promover a inclusão e a justiça social, bem como aperfeiçoar o controle e a fiscalização ambiental na Amazônia. A norma, assim, ao optar por uma abordagem a partir de categorias menores, preserva certa estabilidade e previsibilidade, expressa ideais normativos do direito para o centro das relações humanas, bem como permite que juristas mantenham-se próximos à real "transação da vida", amoldando a lei às necessidades humanas ali existentes. Cabe, assim, aos atores jurídicos, ao se depararem com uma situação relacionada à regularização fundiária na Amazônia Legal, orientar suas decisões em prol desses fins, promovendo, concretamente, os valores subjacentes à normatização da matéria.

Por sua vez, a partir da identificação dos propósitos da norma ao tratar da regularização fundiária na região amazônica, verificando-se que a Lei aproxima-se da ideia de Dagan (2011) e assimila a premissa realista do direito enquanto fenômeno social, entende-se, ainda, que o diploma legal confere as bases para a concepção de uma forma específica da propriedade. Observa-se, nesse sentido, que a legislação propõe, de certo modo, uma inovação institucional, baseada na realidade daquela região, reestruturando a propriedade sob a forma de uma instituição relacionada aos valores humanos existentes nas relações presentes naquele contexto. Dessa sorte, com apoio nessas observações, é possível afirmar que, por possuir características bastante próprias, a propriedade resultante da regularização fundiária de ocupações de terras públicas federais em áreas rurais da Amazônia Legal constitui uma instituição específica da propriedade, denominada, aqui, de propriedade amazônica.

Assim, entende-se que a construção dessa instituição específica da propriedade aproximará o julgador dos problemas humanos existentes naquela região, conferindo-lhe a intimidade necessária para que proceda a suas decisões de forma contextual e normativa e afaste-se de deduções internas com base em formas totalmente abstratas e congeladas. Esse raciocínio, vale dizer, possui importantes consequências práticas, uma vez que, ao contrário de 
obscurecer as motivações subjacentes às escolhas dos julgadores, permite que os inevitáveis juízos de valor sejam realizados de forma racional, convergindo com os propósitos da norma e, por conseguinte, com os valores humanos que se pretende promover com a regularização fundiária na região amazônica.

Por seu turno, tal como as outras formas da propriedade e o direito em geral, a propriedade amazônica, a ser justificada em termos de promoção de valores humanos, deve se submeter a constante reavaliação, de acordo com sua efetividade. Como qualquer instituição da propriedade, pois, demanda um processo permanente de identificação dos valores humanos que lhe são inerentes, havendo que se analisar, como sugere Dagan (2011), os efeitos materiais desse direito na sociedade e no comportamento das pessoas, buscando, sempre, seu aperfeiçoamento.

Diante dessas considerações, entende-se que é possível afirmar que a referida Lei reconhece o papel-chave da propriedade e, convergindo com o pensamento de Waldron (2012) e de Dagan (2011), admite, em alguma medida, que questões sobre propriedade implicam questões sobre justiça, aproximando-se de uma visão mais comprometida com a sociedade como um todo e fazendo transparecer que, de fato, "certas instituições da propriedade podem ser melhores do que outras para a justiça"105 (WALDRON, 2012).

Logicamente, reconhecemos que a Lei não corresponde à solução de todos os problemas fundiários da Amazônia Legal, estando-se, ainda, muito distante desse ideal. A própria norma apresenta incoerências com os propósitos revelados a partir de uma análise conjunta e contextual, tal como visto ao longo do presente estudo. Conforme mencionado, como qualquer objeto regrado pelo direito, é necessário permanente aperfeiçoamento, bem como uma implementação prática efetiva, tanto dos meios para a delimitação das áreas e acesso à política, quanto de uma fiscalização comprometida, honesta e constante. Todavia, ainda que de forma deficiente, percebe-se na Lei de Regularização uma aproximação da visão realista da propriedade e, por conseguinte, a demonstração de que o contexto tão peculiar da Amazônia Legal foi levado em consideração pelo legislador, tratando-se de um passo na direção do maior propósito do direito: a vida.

${ }^{105}$ Tradução livre de: "Certain property institutions may be better than others for justice" (WALDRON, 2012, p. 7). 


\section{REFERÊNCIAS}

ALSTON, Lee J.; LIBECAP, Gary D.; MUELLER, Bernardo. Land Reform Policies, The Sources of Violent Conflict and Implications for Deforestation in the Brazilian Amazon. 2000. Disponível em http://papers.ssrn.com/sol3/papers.cfm?abstract_id=286700. Acesso em 12 set. 2014.

AQUINO, Tomás de. Suma Teológica. São Paulo: Loyola, 2005.

ARISTÓTELES. Política. Tradução de Mário da Gana Kury. Brasília: Editora Universidade de Brasília, 1985.

BANCO CENTRAL DO BRASIL. Manual de Crédito Rural. 2014. Disponível em www.bcb.gov.br. Acesso em 23 nov. 2014.

BLACKSTONE, William (Sir). Commentaries on the Laws of England in Four Books. Notes selected from the editions of Archibold, Christian, Coleridge, Chitty, Stewart, Kerr, and others, Barron Field's Analysis, and Additional Notes, and a Life of the Author by George Sharswood. In Two Volumes. (Philadelphia: J.B. Lippincott Co., 1893). 2011. Disponível em https://archive.org/details/commentariesonl04blacgoog. 2011. Acesso em 13 set. 2014.

BRASIL. Resolução no 76 de 17 de julho de 1822. 1822. Disponível em http://www.quinto.com.br/leis_imperio/resolucao17071822.asp. Acesso em 18 nov. 2014.

Constituição de 1824. Registrada na Secretaria de Estado dos Negocios do Imperio do Brazil a fls. 17 do Liv. $4^{\circ}$ de Leis, Alvarás e Cartas Imperiaes. Rio de Janeiro, 22 de Abril de 1824. Disponível em

http://www.planalto.gov.br/ccivil_03/constituicao/constituicao24.htm. Acesso em 13 set. 2014.

Lei $\mathbf{n}^{\mathbf{0}}$ 601. Publicada na Secretaria de Estado dos Negocios do Imperio em 20 de setembro de 1850. Disponível em http://www.planalto.gov.br/ccivil_03/Leis/L0601-1850.htm. Acesso em 20 nov. 2014.

Lei $\mathbf{n}^{0}$ 1.806. Diário Oficial da União. Poder Legislativo, Rio de Janeiro, 7 de janeiro de 1953. Disponível em http://www2.camara.leg.br/legin/fed/lei/1950-1959/lei-18066-janeiro-1953-367342-publicacaooriginal-1-pl.html. Acesso em 28 nov. 2014.

Lei no 4.504. Diário Oficial da União. Poder Legislativo, Brasília, 30 de novembro de 1964. Disponível em http://www.planalto.gov.br/ccivil_03/leis/14504.htm. Acesso em 15 set. 2014.

Lei $n^{\circ}$ 5.173. Diário Oficial da União. Poder Legislativo, Brasília, 27 de outubro de 1966. Disponível em http://www.planalto.gov.br/ccivil_03/leis/L5173.htm. . Acesso em 16 set. 2014. 
Lei no 6.383. Diário Oficial da União. Poder Legislativo, Brasília, 7 de dezembro de 1976. Disponível em http://www.planalto.gov.br/ccivil_03/leis/16383.htm. Acesso em 10 out. 2014.

Lei Complementar no 31. Diário Oficial da União. Poder Legislativo, Brasília, 11 de outubro de 1977. Disponível em http://www.planalto.gov.br/ccivil_03/leis/lcp/Lcp31.htm. Acesso em 10 out. 2014.

Decreto-Lei no 2.375. Diário Oficial da União, Brasília, 24 de novembro de 1987. Disponível em http://www.planalto.gov.br/ccivil_03/decreto-lei/del2375.htm. Acesso em 10 out. 2014.

Constituição Federal. Diário Oficial da União. Poder Legislativo, Brasília, 5 de outubro de 1988. Disponível em http://www.planalto.gov.br/ccivil_03/constituicao/constituicao.htm. Acesso em 3 set. 2014.

Lei no 8.629. Diário Oficial da União. Poder Legislativo, Brasília, 25 de fevereiro de 1993a. Disponível em http://www.planalto.gov.br/ccivil_03/leis/18629.htm. Acesso em 14 set. 2014.

Lei no 8.666. Diário Oficial da União. Poder Legislativo, Brasília, 21 de junho de 1993b. Disponível em http://www.planalto.gov.br/ccivil_03/leis/18666cons.htm. Acesso em 15 set. 2014.

Decreto no 1775. Diário Oficial da União, Brasília, 8 de janeiro de 1996. Disponível em http://www.planalto.gov.br/ccivil_03/decreto/D1775.htm. Acesso em 2 jan. 2015.

Medida Provisória no 2.183-56. Diário Oficial da União, Brasília, 24 de agosto de 2001. Disponível em http://www.planalto.gov.br/ccivil_03/mpv/2183-56.htm . Acesso em 28 set. 2014.

Código Civil. Diário Oficial da União. Poder Legislativo, Brasília, 10 de janeiro de 2002. Disponível em http://www.planalto.gov.br/ccivil_03/leis/2002/110406.htm . Acesso em 2 set. 2014.

Decreto $\mathbf{n}^{\circ}$ 4.887. Diário Oficial da União, Brasília, 20 de novembro de 2003. Disponível em http://www.planalto.gov.br/ccivil_03/decreto/2003/d4887.htm. Acesso em 15 dez. 2014.

Lei no 11.284. Poder Legislativo, Brasília, 2 de março de 2006a. Disponível em http://www.planalto.gov.br/ccivil_03/_Ato2004-2006/2006/Lei/L11284.htm\#art3x. Acesso em 10 dez. 2014.

Lei no 11.326. Poder Legislativo, Brasília, 24 de julho de 2006b. Disponível em http://www.planalto.gov.br/ccivil_03/_ato2004-2006/2006/lei/111326.htm. Acesso em 2 set. 2014.

. Supremo Tribunal Federal. Mandado de Segurança n 24.753. 2006c. Disponível em 
http://stf.jus.br/portal/jurisprudencia/listarJurisprudencia.asp?s1=\%28MS\%24\%2ESCLA\%2E $+\mathrm{E}+24573 \% 2 \mathrm{ENUME} \% 2 \mathrm{E} \% 29+\mathrm{OU}+\% 28 \mathrm{MS} \% 2 \mathrm{EACMS} \% 2 \mathrm{E}+\mathrm{ADJ} 2+24573 \% 2 \mathrm{EACMS} \% 2$ E\%29\&base=baseAcordaos\&url=http://tinyurl.com/n9hbpdo. Acesso em 10 dez. 2014.

Lei Complementar $\mathbf{n}^{\mathbf{0}}$ 124. Diário Oficial da União. Poder Legislativo, Brasília, 3 de janeiro de 2007a. Disponível em http://www.planalto.gov.br/ccivil_03/leis/lcp/Lcp124.htm. Acesso em 20 nov. 2014.

Supremo Tribunal Federal. Mandado de Segurança no 26.129. 2007b. Disponível em http://stf.jus.br/portal/jurisprudencia/listarJurisprudencia.asp?s1=\%28MS\%24\%2ESCLA\%2E $+\mathrm{E}+26129 \% 2 \mathrm{ENUME} \% 2 \mathrm{E} \% 29+\mathrm{OU}+\% 28 \mathrm{MS} \% 2 \mathrm{EACMS} \% 2 \mathrm{E}+\mathrm{ADJ} 2+26129 \% 2 \mathrm{EACMS} \% 2$ E\%29\&base=baseAcordaos\&url=http://tinyurl.com/nyo82k8. Acesso em 10 dez. 2014.

Exposição de motivos da Medida Provisória no 458. Brasília, 6 de fevereiro de 2009a. Disponível em http://www.planalto.gov.br/ccivil_03/ato2007-2010/2009/Exm/EMI1-MDA-MP-MCidades-09-Mpv-458.htm. Acesso em 20 nov. 2014.

Medida Provisória no 458. Diário Oficial da União. Brasília, 10 de fevereiro de 2009 de 2009b. Disponível em http://www.planalto.gov.br/ccivil_03/_ato20072010/2009/Mpv/458.htm. Acesso em 20 nov. 2014.

Decreto de 27 de abril de 2009. Diário Oficial da União. Brasília, 27 de abril de 2009c. Disponível em http://www.planalto.gov.br/ccivil_03/_ato20072010/2009/Dnn/Dnn12015.htm. Acesso em 20 nov. 2014.

Lei no 11.952. Diário Oficial da União. Poder Legislativo. Brasília, 25 de junho de 2009d. Disponível em http://www.planalto.gov.br/ccivil_03/_ato20072010/2009/lei/l11952.htm. Acesso em 21 ago. 2014.

Lei no 11.977. Diário Oficial da União. Poder Legislativo. Brasília, 7 de julho de 2009e. Disponível em http://www.planalto.gov.br/ccivil_03/_ato20072010/2009/lei/l11977.htm. Acesso em 10 out. 2014.

Decreto no 6.992. Diário Oficial da União. Brasília, 28 de outubro de 2009f. Disponível em http://www.planalto.gov.br/ccivil_03/_ato20072010/2009/Decreto/D6992.htm. Acesso em 23 ago. 2014.

Ministério do Desenvolvimento Agrário. Terra Amazônia Legal: manual de orientação para os parceiros do Programa. 2009g. Disponível em http://www.mda.gov.br/sitemda/sites/sitemda/files/user_arquivos_64/Manual_ParceirosFINAL-END.pdf. Acesso em 10 set. 2014.

Ministério Público Federal. ADI no 4269 (petição inicial). 2009h. Disponível em http://s.conjur.com.br/dl/adi-regularizacao-fu.pdf. Acesso em 3 jan. 2015.

Supremo Tribunal Federal. ADI no 4269 (protocolo). 2009i. Disponível em http://www.stf.jus.br/portal/processo/verProcessoAndamento.asp?incidente=2689764. Acesso em 20 jan. 2015. 
. Ministério do Desenvolvimento Agrário. Saiba mais sobre o programa. [2010]a Disponível em www.portal.mda.gov.br/terralegal/pages/saibamaissobreoprograma. Acesso em 10 set. 2014.

Ministério do Desenvolvimento Agrário. Portaria no 23, de 30 de abril de 2010. Diário Oficial da União. Poder Executivo. Brasília, 05 de maio de 2010b. Disponível em http://www.diariodasleis.com.br/busca/exibelink.php?numlink=214143. Acesso em 14 set. 2014.

Supremo Tribunal Federal. Agravo Regimental no Mandado de Segurança $\mathbf{n}^{\circ}$ 22138. 2013. Disponível em http://redir.stf.jus.br/paginadorpub/paginador.jsp?docTP=TP\&docID=3757364. Acesso em 20 dez. 2014.

Tribunal Regional Federal da $1^{a}$ Região. Apelação em Mandado de Segurança $\mathbf{n}^{\mathbf{o}}$ 0002222277-26.2011.4.01.3600/MT. 2014. Disponível em www.jurisprudencia.trf1.jus.br. Acesso em 10 jan. 2015.

BRITO, B.; BARRETO, P. A regularização fundiária avançou na Amazônia? Os dois anos do programa Terra Legal. Belém: Imazon, 2011. Disponível em http://www.imazon.org.br/publicacoes/livros/a-regularizacao-fundiaria-avancou-naamazoniaos-dois-anos-do-programa-terra-legal-1. Acesso em 25 set. 2014.

BRUM, Eliane. O Olho da Rua. São Paulo: Globo Livros, 2008.

CARVAlHO FILHO, José dos Santos. Manual de Direito Administrativo. Rio de Janeiro: Lumen Juris, 2006.

COHEN, Felix. Field Theory and Judicial Logic. Faculty Scholarship Series. Paper 4362, 1950. Disponível em http://digitalcommons.law.yale.edu/fss_papers/4362 . Acesso em 2 dez. 2014.

COHEN, G. A. Libertad y Dinero. Centro Studios Publicos, 80 primavera, 2000. Disponível em http://www.cepchile.cl/dms/archivo_890_857/rev80_cohen.pdf. Acesso em 20 set. 2014.

CONTI, Bruno Martarello de; ROITMAN, Fábio Brener. Pronaf: uma análise da evolução das fontes de recursos utilizadas no programa. Revista do BNDES: 2011, pp. 132-168.

DAGAN, Hanoch. The Realist Conception of Law. University of Toronto Law Journal, v. 57, n. 3, 2007, pp. 607-660.

Property: values and institutions. Oxford University Press: Oxford, 2011.

Property's Structural Pluralism: on autonomy, the rule of Law, and the role of Blackstonian ownership. (January 14, 2014). 3 Brigham-Kanner Prop. Rts. Conf. J., 2014, Forthcoming. Disponível em http://ssrn.com/abstract=2378999. Acesso em 12 dez. 2014. 
DEWEY, John. The Later Works of John Dewey. Volume 14, 1925 - 1953: 1939 - 1941, Essays, Reviews, and Miscellany (Collected Works of John Dewey 1882-1953) Paperback April 28, 2008.

FACHIN, Luiz Edson. Apreciação Crítica do Código Civil de 2002 na Perspectiva Constitucional do Direito Civil Contemporâneo. Revista Jurídica. São Paulo, n. 304, pp. 1722, fev. 2003.

FALTA de título da terra impede acesso ao crédito. Newsrondônia. Rondônia, 2013. Disponível em http://www.newsrondonia.com.br/noticias/falta+de+titulo+da+terra+impede+acesso+ao+credi to/32363. Acesso em 5 set. 2014.

FAORO, Raymundo. Os donos do poder. São Paulo: Globo, 2009.

FERREIRA, Daniel Brantes. Realismo jurídico norte-americano: origem, contribuições e principais autores. Direito, Estado e Sociedade, n. 40, jan/jun 2012, pp. 6-33.

FUNDO DAS NAÇÕES UNIDAS PARA A INFÂNCIA (UNICEF). Amazônia. [2010]. Disponível em http://www.unicef.org/brazil/pt/where 9425.htm. Acesso em 20 dez. 2014.

GALLIE, W. B. Essentially Contested Concepts. In: Proceedings of the Aristotelian Society, pp. 167-198, 1956.

GILMORE, GRANT. The Ages of American Law. New Haven: Yale University Press, 2014.

GONDINHO, André Osório. Função Social da Propriedade. In: TEPEDINO, Gustavo (Coord.). Problemas de Direito Civil-Constitucional. Rio de Janeiro: Renovar, 2000, pp. 397-433.

GROSSI, Paolo. História da Propriedade e Outros Ensaios. Trad. Luiz Ernani Fritoli; Ricardo Marcelo Fonseca. Renovar: Rio de Janeiro, 2006.

HEGEL, T. W. Princípios da Filosofia do Direito. São Paulo: Martins Fontes, 1997.

HOBBES, T. Leviatã. Os Pensadores. São Paulo: Abril Cultural, 1974.

HOHFELD, Wesley N. Fundamental Legal Conceptions as Applied in Judicial Reasoning. Faculty Scholarship Series. Paper 4378. 1917. Disponível em http://digitalcommons.law.yale.edu/fss_papers/4378. Acesso em 8 set. 2014.

HOLMES JR., Oliver Wendell. The Common Law. New York: Dover, 1991. 1992. The Essential Holmes. Chicago: Chicago University Press,

HONORE, A. M. Ownership. In A.G. Guest (ed.) Oxford Essays in Jurisprudence, Oxford: Oxford University Press, 1961. 
HUME, David. Tratado da natureza humana. São Paulo: UNESP, 2009.

INSTITUTO DO HOMEM E DO MEIO AMBIENTE DA AMAZÔNIA (IMAZON). Nossos valores: sustentabilidade, ética, uso do método científico e excelência na qualidade. [2010]. Disponível em imazon.org.br/institucional/quem-somos/. Acesso em 12 dez. 2014.

KANT, Immanuel. A Metafísica dos costumes. Trad. Edson Bini. São Paulo: Edipro, 2003.

LIMA, Ruy Cirne. 1908: Pequena história territorial do Brasil: Sesmarias e terras devolutas. $4^{a}$ Ed. São Paulo: Secretaria do Estado da Cultura, 1990.

LLEWELLYN, Karl. A Realistic Jurisprudence: the next step. Columbia Law Review, v. $\underline{30, \text { n. 4, Apr., } 1930 .}$

Jurisprudence: realism in theory and practice. New Brunswick:

Transaction Publishers, 2008.

LOCKE, J. Segundo tratado sobre o governo civil. Trad. Magda Lopes e Mariza Lobo

Costa. Petrópolis: Vozes. 1994. Disponível em http://www.xr.pro.br/IF/LOCKE-

Segundo_tratado_Sobre_O_Governo.pdf. Acesso em 2 set. 2014.

MARCUSE, Herbert. Idéias sobre uma teoria crítica da sociedade. Trad. Fausto

Guimarães. Rio de Janeiro: Zahar Editores, 1972.

MARX, Karl. Introdução de 1857. Prefácio à Para a Crítica da Economia Política, Coleção Os Pensadores, Volume Marx I, Nova Cultural, São Paulo, 1987.

. Manuscritos Econômico-Filosóficos, redigidos em 1844. Trad. Jesus Ranieri.

São Paulo: Boitempo Editorial, 2004.

MEIDINGER, E. Property law for development policy and institutional theory: problems of structure, choice, and change. Social science research network (SSRN), 2006. Disponível em http://ssrn.com/abstract=87646. Acesso em 11 set. 2014.

MERRILL, Thomas W; SMITH, Henry E. Optimal Standardization in the Law of Property: the numerus clausus principle, 110, Yale , L. J. 1, 2000.

MERRILL, Thomas W. The Property Prism. Econ Journal Watch8(3) September 2011, p. 247-254. Disponível em http://econjwatch.org/articles/the-property-prism. Acesso em 10 set. 2014.

MÜLLER, Marcos Lutz. O Direito Natural de Hegel: pressupostos especulativos da crítica ao contratualismo. In: JORGE E. Dotti et al. (Org.). Estado e Política: a filosofia política de Hegel. Rio de Janeiro: Jorge Zahar Ed., 2003.

NEVES, Rogério Telles Correia das. Limites Objetivos e Subjetivos à Regularização Fundiária na Amazônia Legal. In: Pro Diviso: estudos da Consultoria Jurídica junto ao Ministério do Desenvolvimento Agrário, n. 08. Brasília, janeiro/fevereiro 2011, pp. 189-208. 
PLATÃo. A República. Trad. Maria Helena da Rocha Pereira. Lisboa: Fundação Calouste Gulbenkian, 1949.

SINGER, Joseph William. The Reliance Interest in Property. Stanford Law Review, v. 40, n. 3, Feb., 1988

SOB PROTESTO de Marina MP da Grilagem é aprovada. Congresso em foco. 2008. Disponível em http://congressoemfoco.uol.com.br/noticias/sob-protesto-de-marina-mp-dagrilagem-e-aprovada/. Acesso em 2 dez. 2014.

SUDAM. Legislação. [2010]. Disponível em http://www.sudam.gov.br/amazonia-legal. Acesso em 22 nov. 2015.

TERRA, Ricardo. A doutrina kantiana da propriedade. Discurso. São Paulo, n. 14, pp. 113143, $1^{\circ}$ semestre de 1983 .

TRECCANI, Girolamo Domenico. Violência e Grilagem: instrumentos de aquisição da propriedade de terras no Pará. Belém: UFPA Universidade Federal do Pará, ITERPAInstituto de Terras do Pará, 2001.

VARELA, Laura Beck. Das Sesmarias à propriedade moderna: um estudo de história do Direito Brasileiro. Rio de Janeiro: Renovar, 2005 .

WALDRON, Jeremy, Property and Ownership. The Stanford Encyclopedia of Philosophy (Spring 2012 Edition), Edward N. Zalta (ed.). 2012. Disponível em http://plato.stanford.edu/archives/spr2012/entries/property/. Acesso em 18 jul. 2014.

WALDRON, Jeremy. The right to private property. Oxford: Claredon Paperbacks, 1988. University Press, 2012.

The rule of law and the measure of property. New York: Cambridge

Property and Ownership. The Stanford Encyclopedia of Philosophy (Spring 2012 Edition), Edward N. Zalta (ed.). 2012. Disponível em http://plato.stanford.edu/archives/spr2012/entries/property/. Acesso em 18 jul. 2014. 